ENVIRONMENTAL RESTORATION PROGRAM

\section{Toxicological Benchmarks for Screening Potential Contaminants of Concern for Effects on Aquatic Biota: 1994 Revision}

\author{
G. W. Suter II \\ J. B. Mabrey
}

\title{
DISCLAIMER
}

This report was prepared as an account of work sponsored by an agency of the United States Government. Neither the United States Government nor any agency thereof, nor any of their employees, makes any warranty, express or implied, or assumes any legal liability or responsibility for the accuracy, completeness, or usefulness of any information, apparatus, product, or process disclosed, or represents that its use would not infringe privately owned rights. Reference herein to any specific commercial product, process, or service by trade name, trademark, manufacturer, or otherwise does not necessarily constitute or imply its endorsement, recommendation, or favoring by the United States Government or any agency thereof. The views and opinions of authors expressed herein do not necessarily state or reflect those of the United States Government or any agency thereof. 



\section{DISCLAIMER}

Portions of this document may be illegible in electronic image products. Images are produced from the best available original document. 


\title{
Toxicological Benchmarks for Screening Potential Contaminants of Concern for Effects on Aquatic Biota: 1994 Revision
}

\author{
G. W. Suter $\mathbf{I}^{\mathbf{1}}$ \\ J. B. Mabrey ${ }^{2}$
}

Date Issued-July 1994

'Environmental Sciences Division

Oak Ridge National Laboratory

Oak Ridge, Tennessee

${ }^{2}$ University of West Florida

Pensacola, Florida

Prepared by

Environmental Sciences Division

Oak Ridge National Laboratory under direction from the

Environmental Restoration Risk Assessment Council

Prepared for

U.S. Department of Energy

Office of Environmental Restoration and Waste Management under budget and reporting code EW 20

OAK RIDGE NATIONAL LABORATORY

Oak Ridge, Tennessee 37831-6285

managed by

MARTIN MARIETTA ENERGY SYSTEMS, INC.

for the

U.S. DEPARTMENT OF ENERGY

under contract DE-AC05-84OR21400 
THIS PAGE INTENTIONALLY LEFT BLANK 


\section{Author Affiliations}

G. W. Suter II is a member of the Environmental Sciences Division, Oak Ridge National Laboratory. J. B. Mabrey is affiliated with the University of West Florida, Pensacola, Florida. 
THIS PAGE INTENTIONALLY LEFT BLANK 


\section{CONTENTS}

TABLES $\ldots \ldots \ldots \ldots \ldots \ldots \ldots \ldots \ldots \ldots \ldots \ldots \ldots \ldots \ldots \ldots \ldots \ldots \ldots$ viii

1. INTRODUCTION $\ldots \ldots \ldots \ldots \ldots \ldots \ldots \ldots \ldots \ldots \ldots \ldots \ldots \ldots \ldots \ldots \ldots$

2. METHODS FOR DERIVING BENCHMARKS $\ldots \ldots \ldots \ldots \ldots \ldots \ldots \ldots 2$

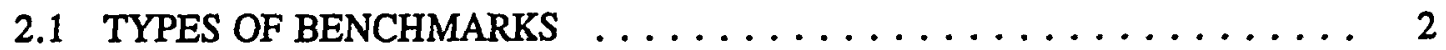

2.2 WATER QUALITY CRITERIA $\ldots \ldots \ldots \ldots \ldots \ldots \ldots \ldots \ldots$

2.3 TIER II VALUES $\ldots \ldots \ldots \ldots \ldots \ldots \ldots \ldots \ldots \ldots \ldots \ldots \ldots \ldots$

2.4 LOWEST CHRONIC VALUES $\ldots \ldots \ldots \ldots \ldots \ldots \ldots \ldots \ldots$

2.5 ESTIMATED LOWEST CHRONIC VALUES $\ldots \ldots \ldots \ldots \ldots \ldots \ldots$

2.6 TEST EC20s $\ldots \ldots \ldots \ldots \ldots \ldots \ldots \ldots \ldots \ldots \ldots \ldots \ldots \ldots \ldots \ldots$

2.7 ESTIMATED TEST EC20s $\ldots \ldots \ldots \ldots \ldots \ldots \ldots \ldots \ldots \ldots 11$

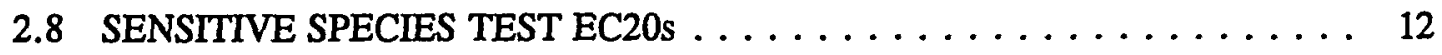

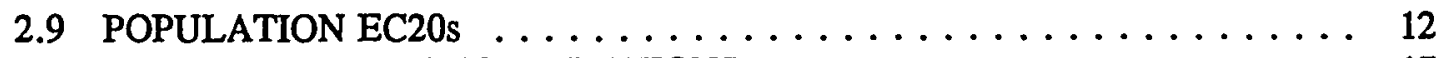

2.10 BACKGROUND CONCENTRATIONS $\ldots \ldots \ldots \ldots \ldots \ldots \ldots \ldots 17$

3. CHEMICAL-SPECIFIC INFORMATION $\ldots \ldots \ldots \ldots \ldots \ldots \ldots \ldots \ldots 17$

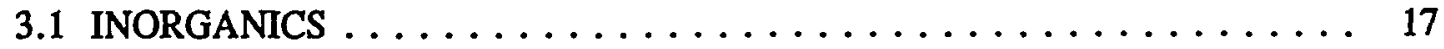

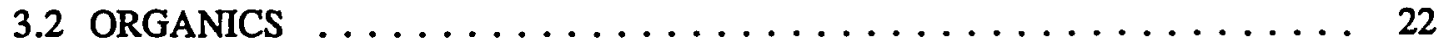

4. COMPARISON OF BENCHMARKS $\ldots \ldots \ldots \ldots \ldots \ldots \ldots \ldots \ldots 29$

5. APPLICATION OF BENCHMARKS $\ldots \ldots \ldots \ldots \ldots \ldots \ldots \ldots \ldots \ldots$

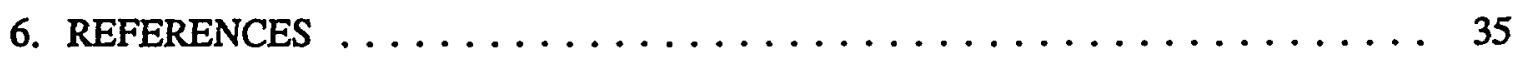

APPENDIX A DATA USED FOR TIER II CALCULATIONS $\ldots \ldots \ldots \ldots \ldots$ A-1

APPENDIX B METHODS FOR DERIVATION OF TIER II VALUES $\ldots \ldots \ldots \ldots$ B-1

APPENDIX $\mathrm{C} \ldots \ldots \ldots \ldots \ldots \ldots \ldots \ldots \ldots \ldots \ldots \ldots \ldots \ldots \ldots \ldots \ldots \ldots \ldots \ldots$ 


\section{TABLES}

Table 1. Summary of conventional benchmarks for priority contaminants in fresh water . 4

Table 2. Summary of alternative benchmarks for priority contaminants in fresh water based on levels of chronic effects . . . . . . . . . . . . . . . . . 13

Table 3. Comparisons of alternative screening benchmarks for aquatic life $\ldots \ldots \ldots$. . 31

Table 4. Amount of data available and used to calculate Tier II values . . . . . . . . 32 


\section{EXECUTIVE SUMMARY}

One of the initial stages in ecological risk assessment of hazardous waste sites is the screening of contaminants to determine which, if any, of them are worthy of further consideration; this process is termed contaminant screening. Screening is performed by comparing concentrations in ambient media to benchmark concentrations that are either indicative of a high likelihood of significant effects (upper screening benchmarks) or of a very low likelihood of significant effects (lower screening benchmarks). Exceedence of an upper screening benchmark indicates that the chemical in question is clearly of concern and remedial actions are likely to be needed. Exceedence of a lower screening benchmark indicates that a contaminant is of concern unless other information indicates that the data are unreliable or the comparison is inappropriate. Chemicals with concentrations below the lower benchmark are not of concern if the ambient data are judged to be adequate.

This report presents potential screening benchmarks for protection of aquatic life from contaminants in water. Because there is no guidance for screening benchmarks, a set of alternative benchmarks is presented herein. The alternative benchmarks are based on different conceptual approaches to estimating concentrations causing significant effects. For the upper screening benchmark, there are the acute National Ambient Water Quality Criteria (NAWQC) and the Secondary Acute Values (SAV). The SAV concentrations are values estimated with $80 \%$ confidence not to exceed the unknown acute NAWQC for those chemicals with no NAWQC. The alternative chronic benchmarks are the chronic NAWQC, the Secondary Chronic Value (SCV), the lowest chronic values for fish and daphnids, the lowest EC20 for fish and daphnids from chronic toxicity tests, the estimated EC20 for a sensitive species, and the concentration estimated to cause a $20 \%$ reduction in the recruit abundance of largemouth bass. It is recommended that ambient chemical concentrations be compared to all of these benchmarks. If NAWQC are exceeded, the chemicals must be contaminants of concern because the NAWQC are applicable or relevant and appropriate requirements (ARARs). If NAWQC are not exceeded, but other benchmarks are, contaminants should be selected on the basis of the number of benchmarks exceeded and the conservatism of the particular benchmark values, as discussed in the text.

To the extent that toxicity data are available, this report presents the alternative benchmarks for chemicals that have been detected on the Oak Ridge Reservation. It also presents the data used to calculate the benchmarks and the sources of the data. It compares the benchmarks and discusses their relative conservatism and utility.

This report supersedes a prior aquatic benchmarks report (Suter et al. 1992). It adds three new types of benchmarks and deletes one which proved to be unreasonably conservative. It also updates the benchmark values where appropriate, adds some new benchmark values, replaces most secondary sources with primary sources, and provides more complete documentation of the sources and derivation of all values. 


\section{INTRODUCTION}

An important early step in the assessment of ecological risks posed by a contaminated site is the screening of contaminants. In many cases, concentrations in water will be reported for more than 100 chemicals, most of which will be reported as undetected at some defined limit of detection. The assessor must decide which of the detected chemicals constitute an ecological hazard and which of the undetected chemicals may pose a hazard at concentrations below the reported detection limits. This screening is done by comparing the reported concentrations to toxicological benchmarks. If concentrations of a chemical exceed its benchmark for a particular medium, then it is worthy of further measurement and assessment. If not, it can be ignored (assuming that the analytical data are adequate).

In practice, a series of benchmarks of differing conservatism may be used. Exceedence of an upper screening benchmark would suggest a severe hazard and a need for urgent action. Nonexceedence of all lower screening benchmarks would suggest no hazard. Exceedence of an increasing number of benchmarks would constitute increasing evidence of the need for measurement and assessment.

The purpose of this report is to present and analyze alternate toxicological benchmarks for screening chemicals for aquatic ecological effects. Screening benchmarks have not been previously proposed, and no guidance for developing such values is available from the U.S. Environmental Protection Agency (EPA) or other regulatory agencies. In general, the National Ambient Water Quality Criteria (NAWQC) for Protection of Aquatic Life have been used for this purpose. However, they were not designed for contaminant screening. They are intended to protect most aquatic species most of the time with reasonable confidence. Because screening benchmarks are intended to provide a high degree of confidence that a chemical is not hazardous, greater conservatism may be warranted. In addition, the NAWQC do not correspond to any particular type or level of effect (Suter et al. 1987). Because screening assessments are performed as the preliminary stage to ecological risk assessments, it is appropriate to consider potential toxicological benchmarks that correspond to defined types and levels of effects. Finally, and most importantly, NAWQC are available for only a small proportion of chemicals.

This compilation is limited to chemicals that have been detected on the Oak Ridge Reservation and to benchmarks derived from studies of toxic effects on fresh water organisms. The list of chemicals detected on the Oak Ridge Reservation includes 45 metals and 105 industrial chemicals. Only four pesticides occur on the list, and those are persistent and wide-spread (chlordane, DDT, heptachlor, and lindane).

This report supersedes a prior aquatic benchmarks report (Suter et al. 1992). It adds three new types of benchmarks and deletes one that proved to be unreasonably conservative (the advisory values). It also updates the benchmark values where appropriate, adds some new benchmark values, replaces most secondary sources with primary sources, and provides more complete documentation of the sources and derivation of all values. 


\section{METHODS FOR DERIVING BENCHMARKS}

\subsection{TYPES OF BENCHMARKS}

The simplest screening benchmarks are toxicity test endpoints. A test endpoint is a statistically derived numeric summary of the results of a toxicity test. Test endpoints can be calculated in two ways. First, a level of effect can be estimated by fitting a function such as the probit or logit to the concentration-response data to derive a concentration-response model. Then by inverse regression, a concentration can be estimated that causes a particular level of effect such as the median lethal concentration (LC50). Second, hypothesis testing statistics can be used to determine whether each of the tested concentrations caused an effect that was statistically significantly different from the controls. The lowest concentration causing such an effect is termed the Lowest Observed Effect Concentration (LOEC); the highest concentration for which there were no such effects is termed the No Observed Effect Concentration (NOEC). The geometric mean of the LOEC and NOEC is termed the Chronic Value (CV) and was formerly termed the Maximum Acceptable Toxicant Concentration (MATC).

Toxicity tests are conventionally divided into acute and chronic tests. Standard acute aquatic toxicity tests are 48 or 96 hours in duration and use juvenile or adult organisms; the test endpoints are the median lethal concentration (LC50) or median effective concentration (EC50) for death or some equivalent effect (e.g., immobilization). Standard chronic tests include all or most of the lifecycle of the test organisms, and they include observations of growth, deformities, and reproductive success as well as lethality. The standard endpoint for chronic tests is the CV.

Another important distinction is between response-specific and integrative endpoints. Conventionally, NOECs and LOECs are calculated for each response parameter, and the results for the most statistically sensitive parameter are reported. Because effects on populations and ecosystems are a result of the integrated effects of the toxicant on all life stages, it is more sensible to integrate the responses in the test when calculating the test endpoint. Integrative endpoints may be simple arithmetic combinations of effects such as the proportional mortality across all tested life stages or population parameters derived from simple models such as the intrinsic rate of natural increase, $r$.

Benchmarks may be combinations of multiple test endpoints. An example is the chronic NAWQC, which are derived from at least eight LC50s and three CVs.

Finally, benchmarks may be derived by using mathematical models to simulate an assessment endpoint, a specific environmental characteristic that is valued and is at risk due to the contamination or disturbance that is being assessed (Suter 1989). For example, in this study we present concentrations estimated to correspond to a $20 \%$ reduction in recruit abundance for largemouth bass (Micropterus salmoides) because production of fish, particularly game fish, is an assessment endpoint for Oak Ridge Reservation ecological risk assessments (Suter et al. 1992).

Conventional aquatic benchmarks, which are based on regulatory criteria or standard test endpoints used to derive criteria, are listed in Table 1. Unconventional aquatic benchmarks, which are based on levels of effects on integrative endpoints, are listed in Table 2. 


\subsection{WATER QUALITY CRITERIA}

The NAWQC are applicable or relevant and appropriate requirements (ARARs); therefore, they provide the basis for the screening benchmarks for contaminants in water. The acute NAWQC are calculated by the EPA as half the Final Acute Value (FAV), which is the fifth percentile of the distribution of 48- to 96-hour LC50 values or equivalent median effective concentration EC50 values for each criterion chemical (Stephan et al. 1985). The acute NAWQC are intended to correspond to concentrations that would cause less than $50 \%$ mortality in 5\% of exposed populations in a brief exposure. They may be used as a reasonable upper screening benchmark because waste site assessments are concerned with sublethal effects and largely with continuous exposures, rather than the lethal effects and episodic exposures to which the acute NAWQC are applied. The chronic NAWQC are the FAVs divided by the Final Acute-Chronic Ratio (FACR), which is the geometric mean of quotients of at least three LC50/CV ratios from tests of different families of aquatic organisms (Stephan et al. 1985). It is intended to prevent significant toxic effects in chronic exposures and is used in this assessment as one possible lower screening benchmark. The NAWQC are listed in Table 1.

NAWQC for several metals are functions of water hardness; the criteria are lower for lower hardness levels. The criteria for $100 \mathrm{mg} / \mathrm{L}$ hardness as reported by the EPA are presented in this report. That hardness is near the lower end of the range of hardness values reported for the Oak Ridge Reservation, so it is moderately conservative. For sites with different water hardnesses, site-specific criteria should be calculated. The formulas for hardness correction are listed in the discussions of individual chemicals.

Many readers will note that the EPA's compilations of NAWQC contain values for many chemicals that have no NAWQC listed herein (EPA 1986b); the EPA lists lowest CVs for those chemicals for which there is not enough data to calculate a criterion but for which there is at least one CV. Lowest CVs are treated as a separate category of benchmarks in this compilation.

Some chronic NAWQC are based on protection of humans or other piscivorous organisms rather than protection of aquatic organisms. Those criteria are not included herein because screening for risks to wildlife or humans is performed by other methods. However, if sufficient data were available to calculate a final chronic value (FCV) for those chemicals, then the FCV are presented in place of the chronic NAWQC in Table 1, and its derivation is noted.

For particular chemicals, the lower screening benchmark could be lower than the chronic NAWQC for any one of the following reasons. First, the chronic NAWQC are based on a threshold for statistical significance rather than biological significance. In some chronic tests, because of highly variable results, the statistical threshold corresponds to greater than $50 \%$ effect on a response parameter (Stephan and Rogers 1985, Suter et al. 1987). Second, not all important responses are included in the subchronic toxicity tests that are used to calculate many 


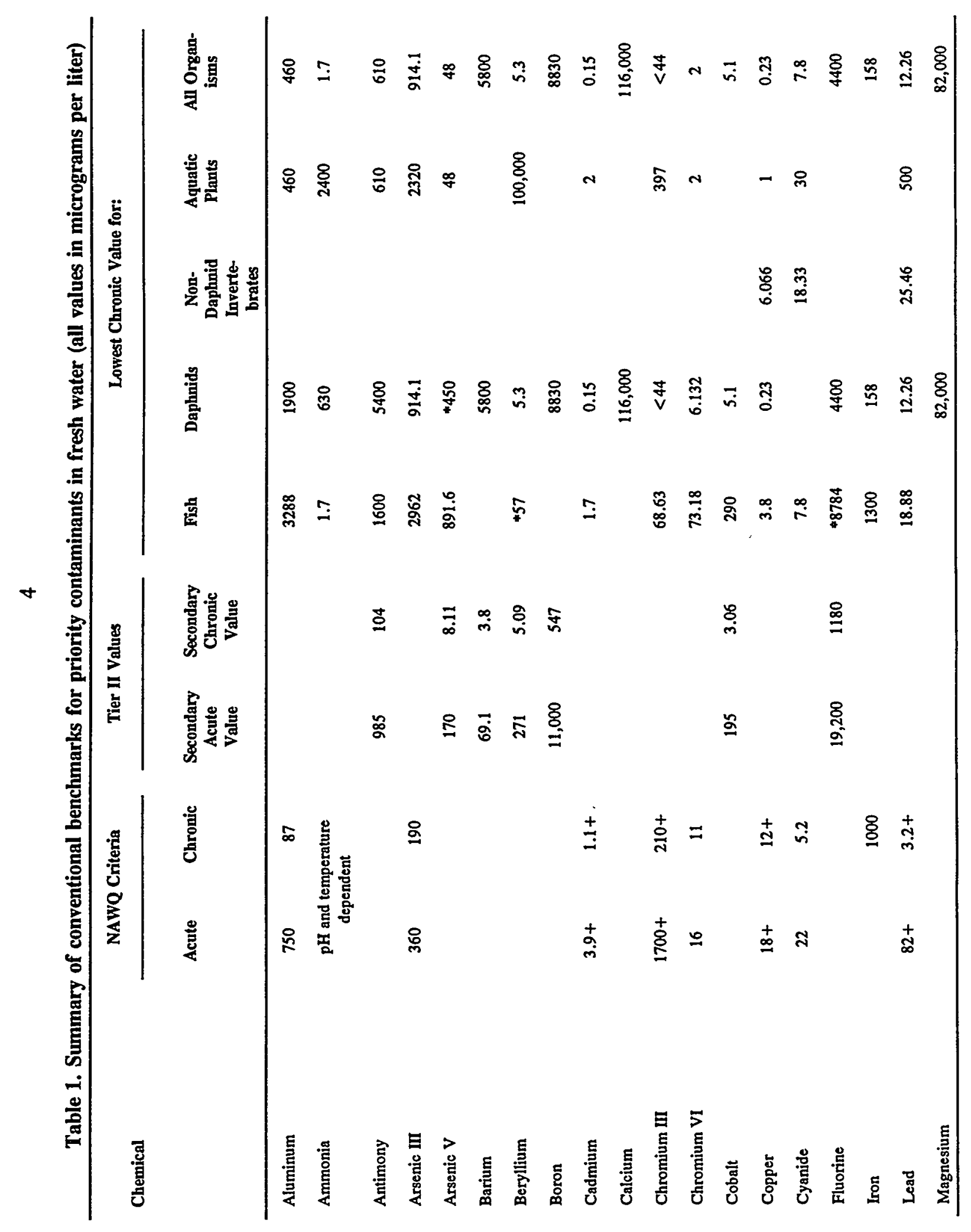




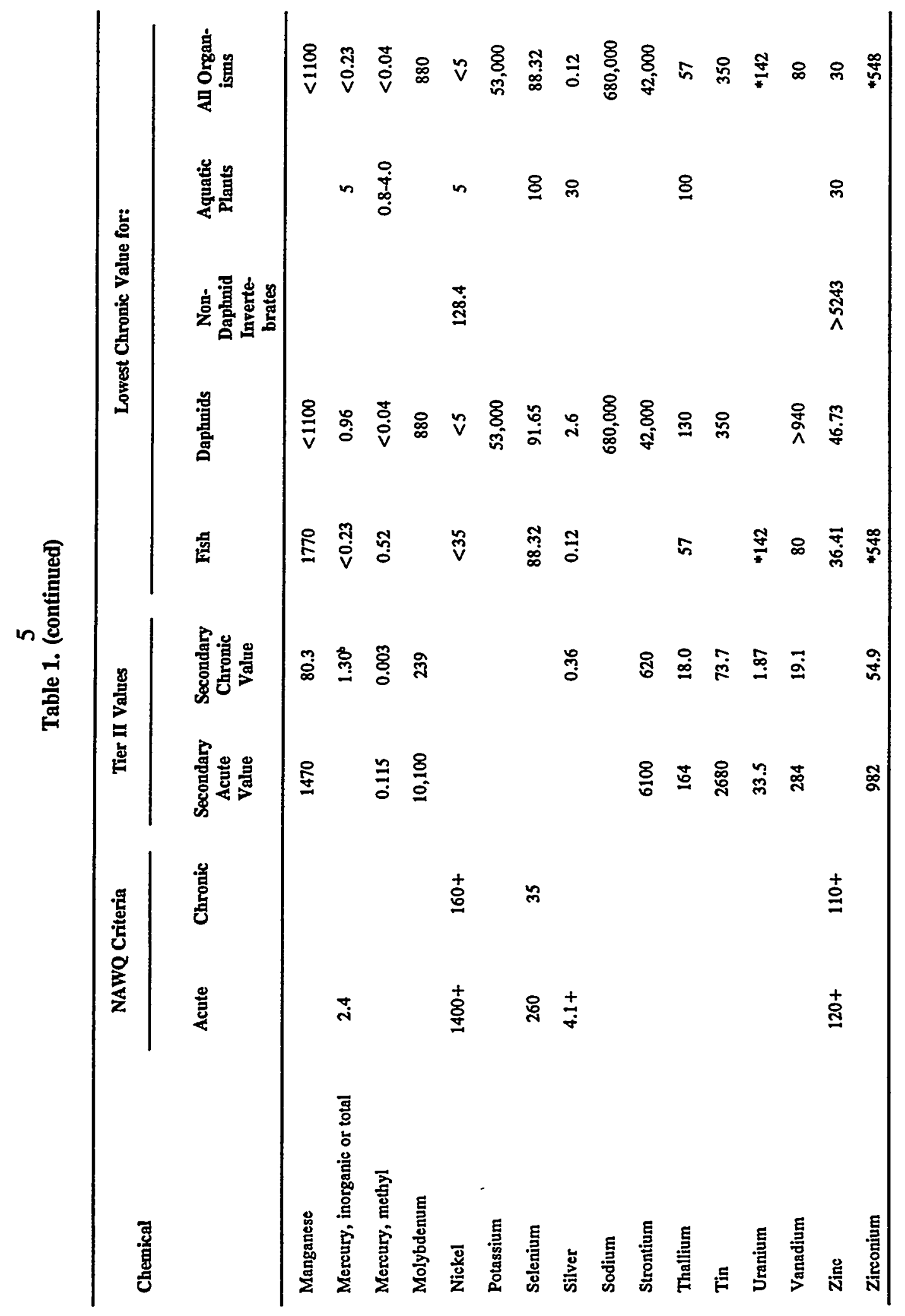




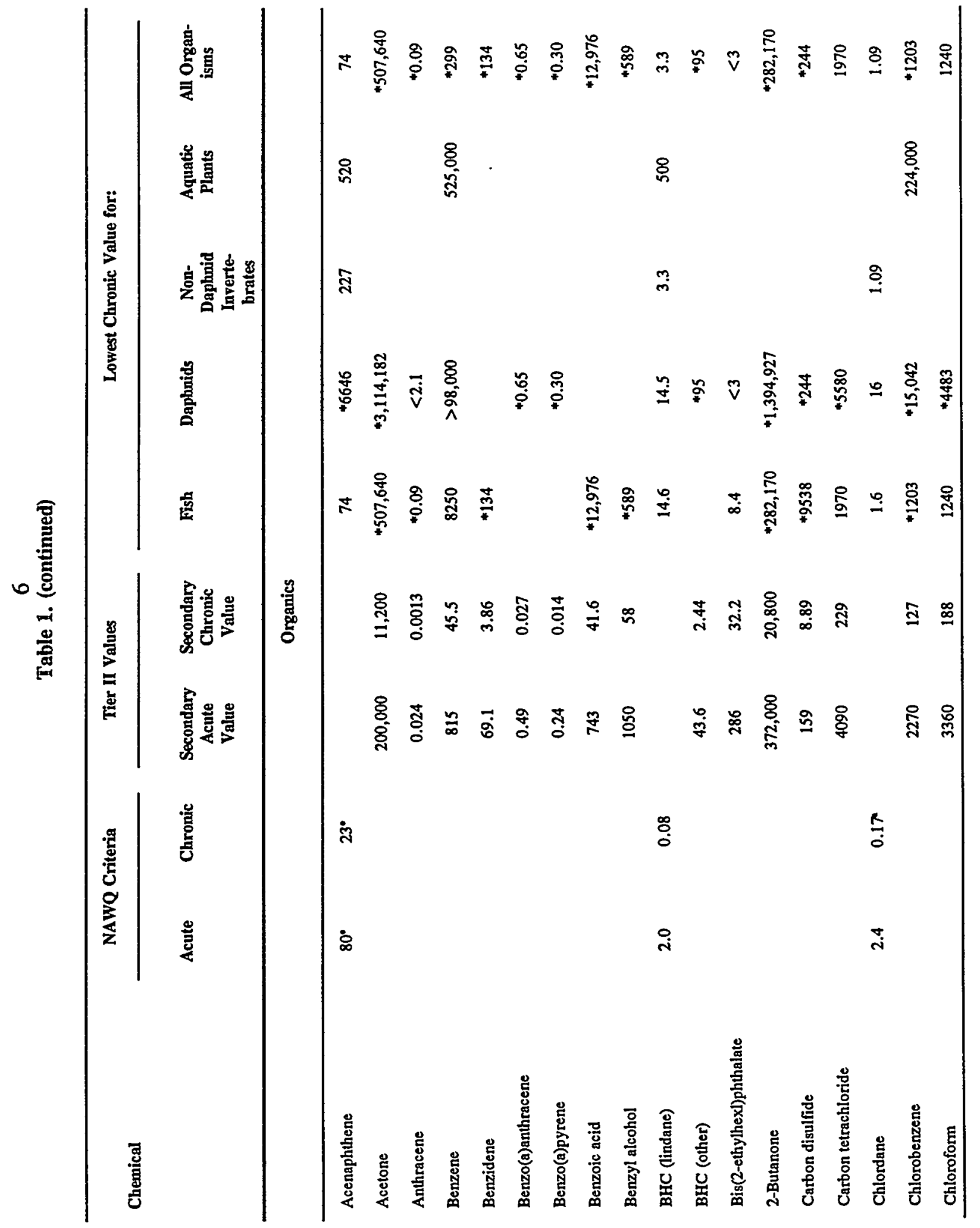




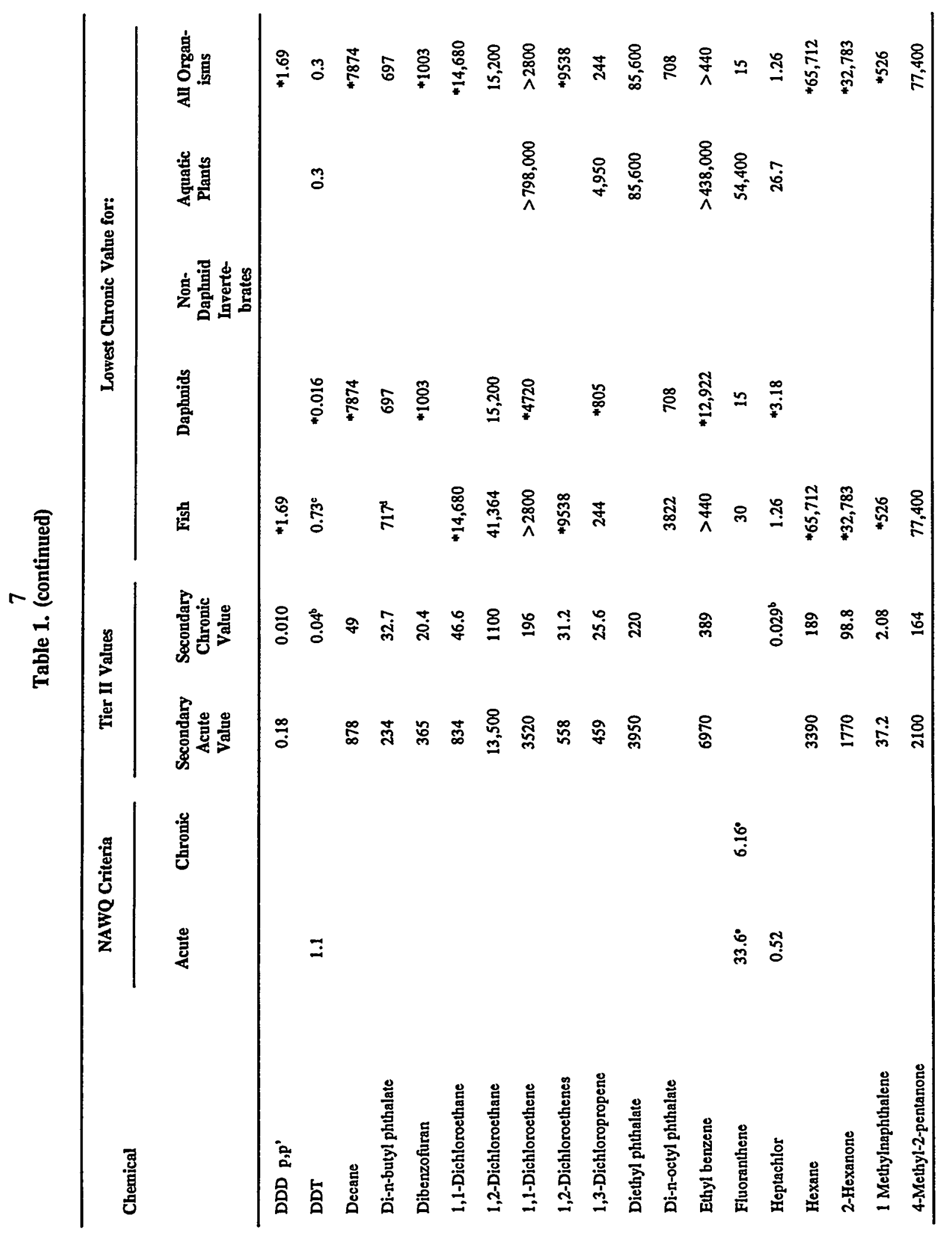




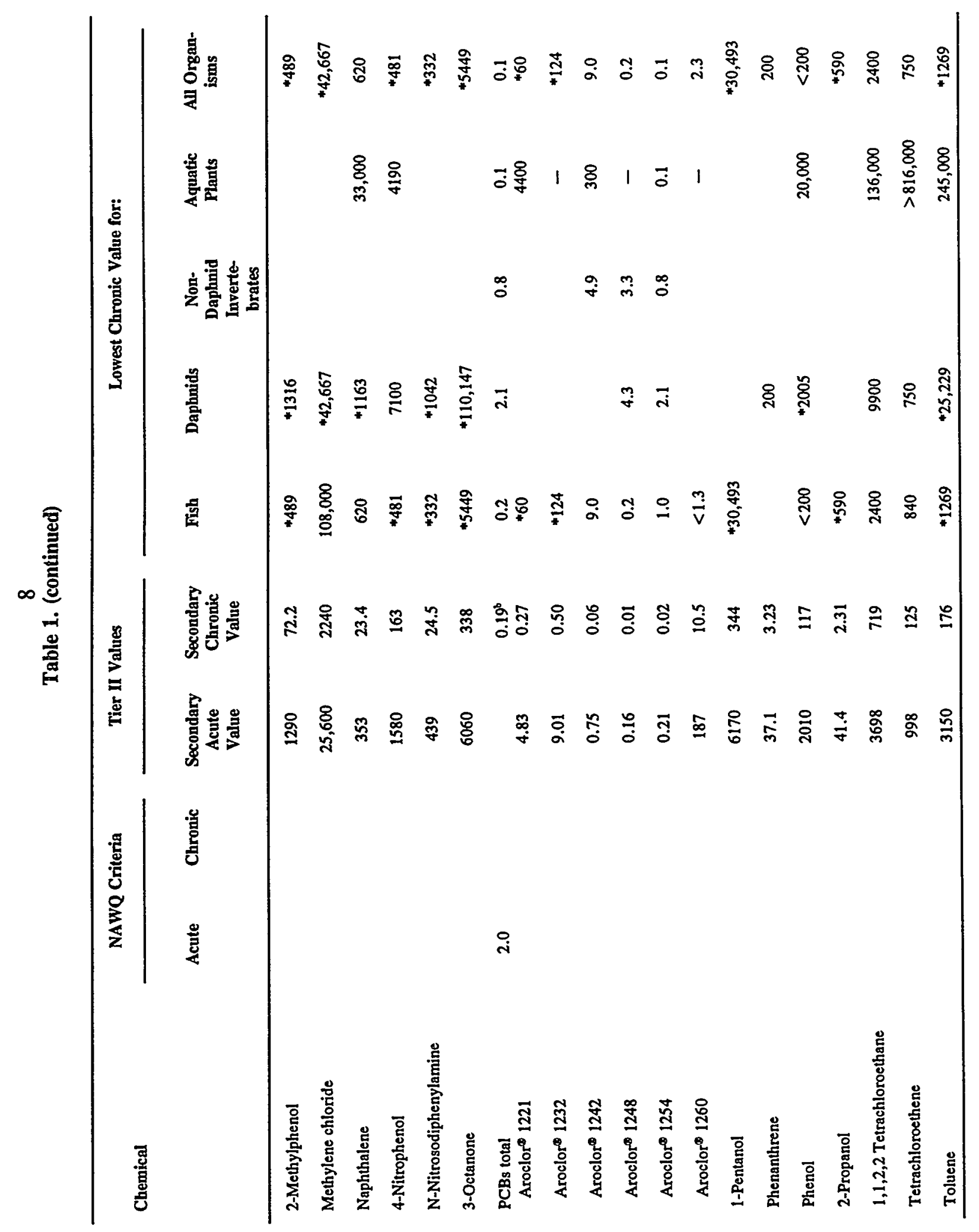




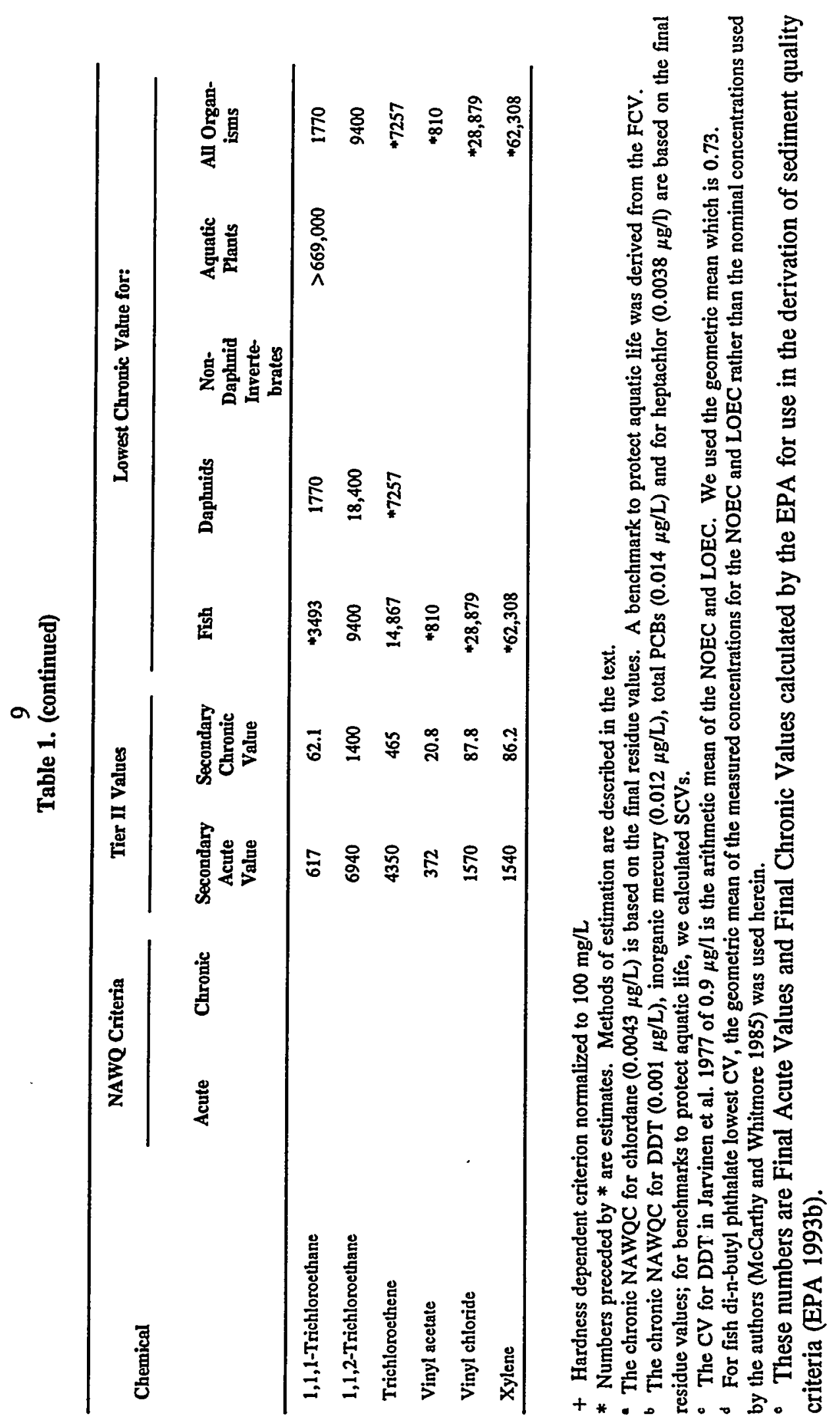


chronic NAWQC. In particular, effects on fecundity, which is the most sensitive response parameter on average in fish toxicity tests (Suter et al. 1987), are often not included. Third, the chronic NAWQC are based on the most statistically sensitive of the measured response parameters in each chronic or subchronic test. Therefore, cumulative effects over the lifecycle of fish and invertebrates are not considered. Fourth, the NAWQC are set at a level that protects "most species most of the time." Finally, many of the NAWQC have not been revised since 1980 so they do not incorporate recent data that are included in the calculation of other benchmarks. These concerns are confirmed by the recent finding that nickel concentrations (on the Oak Ridge Reservation) that are below chronic NAWQC are nonetheless toxic to daphnids (Kszos et al. 1992).

\subsection{TIER II VALUES}

If NAWQC were not available for a chemical, the Tier II method described in the EPA's Proposed Water Quality Guidance for the Great Lakes System was applied (EPA 1993a). Tier II values were developed so that aquatic benchmarks could be established with fewer data than are required for the NAWQC. The Tier II values presented in this report are concentrations that would be expected to be higher than NAWQC in no more than $20 \%$ of cases.

The Tier II values equivalent to the FAV and FCV are the SAVs and SCVs, respectively. The sources of data for the Tier II values are listed in Appendix A, and the procedure and factors used to calculate the SACs and SCVs are in Appendix B. The methods described herein differ from those in EPA (1993a) in two respects. First, the Great Lakes SAVs require an LC50 for a daphnid, but that requirement would severely restrict the number of benchmarks that could be calculated. The EPA has provided factors for calculating SAVs when no daphnid LC50s are available, and these factors are used herein (Stephan 1991). Second, the calculation of SAVs for the Great Lakes require high quality standard LC50 and EC50 values. Only high quality standard data are used in this document if such values are available for a chemical. However, when no such values are available, nonstandard or lower quality LC50s are used. This deviation is justified by the use of the SAVs derived herein for screening purposes as opposed to the SAVs for the Great Lakes which are intended for regulatory purposes.

\subsection{LOWEST CHRONIC VALUES}

The lowest chronic values for fish and invertebrates reported in the literature are potential lower benchmarks. Chronic values are used to calculate the chronic NAWQC, but the lowest chronic value may be lower than the chronic NAWQC. Because of the short generation time of algae and the relative lack of standard chronic tests for aquatic plants, EPA guidelines are followed in using any algal test of at least 96-hour duration and any biologically meaningful response for the plant values.

\subsection{ESTIMATED LOWEST CHRONIC VALUES}

Estimated lowest chronic values for fish and invertebrates are another set of potential lower 
benchmarks. Estimated chronic values were extrapolated from 96-hour LC50s using equations from Suter et al. (1987) and Suter (1993). The equations are as follows where LC50 equals the lowest species mean 96-hour LC50 for fish and 48-hour EC50 for daphnids, and CV equals the estimated chronic value for that taxon. The $95 \%$ prediction interval at the mean is $\log C V \pm$ the PI value (95\% prediction intervals contain $95 \%$ of observations versus $95 \%$ confidence intervals which contain the mean with $95 \%$ confidence).

Fish CV for a metallic contaminant:

$$
\begin{aligned}
\log C V= & 0.73 \log \mathrm{LC} 50-0.70 \\
& P I=1.2
\end{aligned}
$$

Fish CV for a nonmetallic contaminant:

$$
\begin{aligned}
& \log C V= 1.07 \log \text { LC50 }-1.51 \\
& \text { PI }=1.5
\end{aligned}
$$

Daphnid CV for a metallic contaminant:

$$
\begin{aligned}
\log C V= & 0.96 \log \text { LC50 }-1.08 \\
& \text { PI }=1.56
\end{aligned}
$$

Daphnid CV for a nonmetallic contaminant:

$$
\begin{aligned}
& \log C V= 1.11 \log \text { LC50 }-1.30 \\
& \text { PI }=1.35
\end{aligned}
$$

\subsection{TEST EC20s}

Another potential lower benchmark is the test EC20 for fish, which is defined as the highest tested concentration causing less than $20 \%$ reduction in 1) the weight of young fish per initial female fish in a lifecycle or partial life-cycle test or 2) the weight of young per egg in an early life-stage test. A similar potential lower benchmark is the test EC20 for daphnids, which is the highest tested concentration causing less than $20 \%$ reduction in the product of growth, fecundity, and survivorship in a chronic test with a daphnid species. (Daphnids include members of the genera Daphnia, Ceriodaphnia, and Simocephalus.) These benchmarks are intended to be indices of population production. They are equivalent to chronic values in that they are simply a summary of the results of chronic toxicity tests, and in most cases the same test supplied the lowest chronic value and the lowest test EC20. However, the test EC20s are based on a level of biological effect rather than a level of statistical significance, and they integrate all of the stages of the toxicity test rather than treating each response independently. The $20 \%$ figure was chosen as approximately the mean level of effect on individual response parameters observed at CVs and as a minimum detectable difference in population characteristics in the field (Suter et al. 1987, 1992). These values are listed in Table 2.

\subsection{ESTIMATED TEST EC20s}

The estimated test EC20 is another potential benchmark. The estimated values were extrapolated from 96-hour LC50 values using equations from Suter (1992). The equation for the lowest fish test EC20 is as follows where LC50 equals the lowest species mean 96-hour LC50 
for fish, and the EC25 for weight of juveniles per egg is used as an estimate of the test EC20 value. (The difference between $20 \%$ and $25 \%$ effect is trivial given the uncertainties in these estimates and the steepness of the concentration-response curves.) The log-scaled $95 \%$ prediction interval at the mean is $\log \mathrm{EC} 25 \pm$ the $\mathrm{PI}$ value:

$$
\begin{aligned}
\log \mathrm{EC} 25= & 0.90 \log \mathrm{LC} 50-0.86 \\
& \mathrm{PI}=1.6
\end{aligned}
$$

These values are listed in Table 2 for those chemicals that have no empirical test EC20.

\subsection{SENSITIVE SPECIES TEST EC20s}

The sixth potential benchmark is the EC20, adjusted to approximate the fifth percentile of the species sensitivity distribution. It is calculated in the same way as the chronic NAWQC except that the test EC20s are used in place of CVs, and salt water species were not included. The FAV for each of the criterion chemicals was divided by the geometric mean of ratios of LC50s to EC20s. These benchmarks are referred to as sensitive species (SS) test EC20s, and are listed in Table 2.

\subsection{POPULATION EC20s}

The last potential benchmark is an estimate of the continuous concentration that would cause a 20\% reduction in the recruit abundance of largemouth bass. The method used was described by Barnthouse et al. (1990) and is briefly summarized herein. The recruit abundance estimates are generated by a matrix model of a reservoir largemouth bass population (Bartell 1990). The fecundity, hatching success, larval survival, and post-larval survival of the model population are each decremented by a value generated from statistical extrapolation models. For each life stage for which a concentration-response relationship could be calculated, that relationship was adjusted for the relative sensitivity of the test species and the bass. For those life stages with no concentration-response relationship, the relationship was estimated using life stage to life stage extrapolation models, and the taxonomic adjustment was made. However, if the authors of the study reported that life stage was unaffected, the decrement for that life stage was set to zero. If no chronic test data were available, extrapolations from LC50s to chronic responses of each life stage were performed. Uncertainties in all of these extrapolations were propagated through the models to generate estimates of uncertainty. For each chemical, each available freshwater fish chronic test was used to parameterize a model run. If no chronic test data were available, each available freshwater fish LC50 was used to parameterize a model run. The results are presented in Appendix C. The geometric mean of all population EC20 estimates for each. chemical is reported in Table 2. 
Table 2. Summary of alternative benchmarks for priority contaminants in fresh water based on levels of chronic effects (all values in micrograms per liter)

\begin{tabular}{|c|c|c|c|c|}
\hline \multirow{2}{*}{ Chemical } & \multicolumn{2}{|c|}{ Lowest Test $\mathrm{EC}_{20}$ for: } & \multirow{2}{*}{$\begin{array}{c}\text { Sensitive } \\
\text { Species Test } \\
\text { EC }_{20}\end{array}$} & \multirow{2}{*}{$\begin{array}{l}\text { Population } \\
\text { EC }_{20}\end{array}$} \\
\hline & Fish & Daphnids & & \\
\hline Aluminum & 4700 & 540 & 75 & \\
\hline Antimony & 2310 & 1900 & & 79 \\
\hline Arsenic III & 2130 & 633 & 55 & 1995 \\
\hline Arsenic V & 1500 & $>932$ & & 185 \\
\hline \multicolumn{5}{|l|}{ Barium } \\
\hline Beryllium & $* 148$ & 3.8 & & 21 \\
\hline Boron & & 7 & & \\
\hline Cadmium & 1.8 & 0.75 & $0.013^{a}$ & 4.3 \\
\hline \multicolumn{5}{|l|}{ Calcium } \\
\hline Chromium III & 89 & & 8.44 & 126 \\
\hline Chromium VI & 51 & 0.5 & 0.266 & 316 \\
\hline Cobalt & 810 & $<4.4$ & & 3.98 \\
\hline Copper & 5 & 0.205 & 0.26 & 8.6 \\
\hline Cyanide & 5.3 & & 1.17 & 11 \\
\hline Fluorine & $* 5336$ & 3706 & & 1080 \\
\hline Iron & & 16 & & \\
\hline Lead & 22 & & 0.35 & 71 \\
\hline \multicolumn{5}{|l|}{ Magnesium } \\
\hline Manganese & 1270 & $<1100$ & & 112 \\
\hline Mercury, inorganic & 0.87 & 0.87 & 0.18 & 0.32 \\
\hline Mercury, methyl & $<0.03$ & 0.87 & & 0.28 \\
\hline Molybdenum & & 360 & & \\
\hline Nickel & 62 & 45 & $11^{\bullet}$ & 215 \\
\hline \multicolumn{5}{|l|}{ Potassium } \\
\hline Selenium & 40 & 25 & 2.60 & \\
\hline Silver & 0.20 & $<0.56$ & $0.14^{\circ}$ & 0.32 \\
\hline \multicolumn{5}{|l|}{ Sodium } \\
\hline \multicolumn{5}{|l|}{ Strontium } \\
\hline Thallium & 81 & 64 & & 67 \\
\hline
\end{tabular}


14

Table 2. (continued)

\begin{tabular}{|c|c|c|c|c|}
\hline \multirow[b]{2}{*}{ Chemical } & \multicolumn{2}{|c|}{ Lowest Test $\mathrm{EC}_{20}$ for: } & \multirow{2}{*}{$\begin{array}{c}\text { Sensitive } \\
\text { Species Test } \\
\text { EC }_{20}\end{array}$} & \multirow{2}{*}{$\begin{array}{c}\text { Population } \\
\mathrm{EC}_{20}\end{array}$} \\
\hline & Fish & Daphnids & & \\
\hline \multicolumn{5}{|l|}{$\operatorname{Tin}$} \\
\hline Uranium & *455 & & & 27 \\
\hline Vanadium & 41 & 430 & & 32 \\
\hline Zine & 47 & & 21 & 80 \\
\hline Zirconium & *2396 & & & 251 \\
\hline \multicolumn{5}{|c|}{ Organics } \\
\hline Acenaphthene & $<197$ & & & \\
\hline Acetone & $* 161,867$ & & & 23,714 \\
\hline Anthracene & $* 0.35$ & $>8.2$ & & \\
\hline Benzene & 21 & & & 229 \\
\hline Benzidene & *158 & & & 68 \\
\hline \multicolumn{5}{|l|}{ Benzo(a)anthracene } \\
\hline Benzo(a)pyrene & $>2.99$ & & & \\
\hline Benzoic acid & $* 7409$ & & & 1259 \\
\hline Benzyl alcohol & *550 & & & 375 \\
\hline BHC (lindane) & $<1.1$ & 11 & 0.11 & \\
\hline \multicolumn{5}{|l|}{ BHC (other) } \\
\hline Bis(2-ethylhexl)phthalate & $>54$ & $<3$ & & 50 \\
\hline 2-Butanone & $* 98,772$ & & & 17,783 \\
\hline Carbon disulfide & *5719 & & & 1000 \\
\hline Carbon tetrachloride & 65 & & & 224 \\
\hline Chlordane & $<0.25$ & 12.1 & 0.50 & 0.71 \\
\hline Chlorobenzene & 1002 & & & 165 \\
\hline \multicolumn{5}{|l|}{ Chloroethane } \\
\hline Chloroform & 8400 & & & 562 \\
\hline DDD p,p' & *3.99 & & & 0.61 \\
\hline DDT & 0.35 & & 0.008 & \\
\hline Decane & & & & \\
\hline
\end{tabular}


15

Table 2. (continued)

\begin{tabular}{|c|c|c|c|c|}
\hline \multirow{2}{*}{ Chemical } & \multicolumn{2}{|c|}{ Lowest Test $\mathbf{E C}_{20}$ for: } & \multirow{2}{*}{$\begin{array}{c}\text { Sensitive } \\
\text { Species Test } \\
\text { EC }_{\mathbf{2 0}}\end{array}$} & \multirow{2}{*}{$\begin{array}{c}\text { Population } \\
\qquad \mathbf{E C}_{\mathbf{2 0}}\end{array}$} \\
\hline & Fish & Daphnids & & \\
\hline Di-n-butyl phthalate & 270 & 500 & & 251 \\
\hline \multicolumn{5}{|l|}{ Dibenzofuran } \\
\hline 1,1-Dichloroethane & $* 8219$ & & & 1585 \\
\hline 1,2-Dichloroethane & 29,000 & $<11,000$ & & 1259 \\
\hline 1,1-Dichloroethene & & & & 447 \\
\hline 1,2-Dichloroethenes & *5719 & & & \\
\hline 1,3-Dichloropropene & $* 350$ & & & 40 \\
\hline Diethyl phthalate & & & & 1000 \\
\hline Di-n-octyl phthalate & $<100$ & 310 & & 1995 \\
\hline Ethyl benzene & & & & 398 \\
\hline Fluoranthene & & & & 32 \\
\hline Heptachlor & 0.86 & & 0.004 & 0.1 \\
\hline Hexane & $* 28,995$ & & & \\
\hline 2-Hexanone & $* 16,155$ & & & 1259 \\
\hline 1-Methylnaphthalene & $* 500$ & & & 31.62 \\
\hline 4-Methyl-2-pentanone & & & & 1585 \\
\hline 2-Methylphenol & *470 & & & 74 \\
\hline Methylene chloride & 410 & & & 1259 \\
\hline Naphthalene & 450 & $>600$ & & 1000 \\
\hline 4-Nitrophenols & $* 464$ & 5000 & & 60 \\
\hline N-Nitrosodiphenylamine & *339 & & & 40 \\
\hline 3-Octanone & $* 3571$ & & & \\
\hline $\begin{array}{l}\text { PCBs total } \\
\text { Aroclor } 1221\end{array}$ & $\begin{array}{l}0.4 \\
* 80\end{array}$ & 1.2 & & $\begin{array}{c}0.63 \\
10\end{array}$ \\
\hline Aroclor 1232 & $* 148$ & & & 16 \\
\hline Aroclor 1242 & $<2.9$ & & & 1.58 \\
\hline Aroclor 1248 & 0.4 & 2.5 & & 1.26 \\
\hline Aroclor 1254 & 0.52 & 1.2 & & 0.63 \\
\hline Aroclor 1260 & 2.1 & & & 316 \\
\hline 1-Pentanol & $* 15,200$ & & & 3548 \\
\hline
\end{tabular}


16

Table 2. (continued)

\begin{tabular}{|c|c|c|c|c|}
\hline \multirow{2}{*}{ Chemical } & \multicolumn{2}{|c|}{ Lowest Test $\mathrm{EC}_{20}$ for: } & \multirow{2}{*}{$\begin{array}{c}\text { Sensitive } \\
\text { Species Test } \\
\text { EC }_{20}\end{array}$} & \multirow{2}{*}{$\begin{array}{c}\text { Population } \\
\mathrm{EC}_{20}\end{array}$} \\
\hline & Fish & Daphnids & & \\
\hline Phenanthrene & & 110 & & \\
\hline Phenol & $<230$ & & & 4467 \\
\hline 2-Propanol & $* 35,381$ & & & 3162 \\
\hline 1,1,2,2-Tetrachloroethane & 1400 & $<420$ & & 1585 \\
\hline Tetrachloroethene & 500 & 510 & & 50 \\
\hline Toluene & $<26$ & & & 200 \\
\hline 1,1,1-Trichloroethane & $* 2457$ & 1300 & & 251 \\
\hline 1,1,2-Trichloroethane & 14,800 & 13,000 & & 15,849 \\
\hline Trichloroethene & 5758 & & & 232 \\
\hline Vinyl acetate & $* 718$ & & & 108 \\
\hline Vinyl chloride & $* 14,520$ & & & \\
\hline Xylene & 2680 & & & \\
\hline
\end{tabular}

* Numbers preceded by * are estimates. Methods of estimation are described in the text.

a Study LC50's were used rather than species mean LC50s so water hardness would correspond to EC20 values. 


\subsection{BACKGROUND CONCENTRATIONS}

Background water concentrations should be used as a check for these benchmarks. That is, because some of these benchmarks are quite conservative and because the measured concentrations in ambient water may include forms that are not bioavailable, benchmark concentrations may be lower than background water concentrations. If the background concentrations are valid and represent an uncontaminated state and if the background sites support biotic communities characteristic of uncontaminated sites in the same region and with equivalent habitat quality, then screening benchmarks lower than the background concentration should not be used.

\section{CHEMICAL-SPECIFIC INFORMATION}

This section describes the sources of information and procedures that are specific to individual elements. Except where noted, the sources of data for estimating chronic values and test EC20s for fish are the same. All data used to calculate Tier II values and estimated chronic values and EC20s are presented in Appendix A.

\subsection{INORGANICS}

Aluminum. There are NAWQC for aluminum. The toxicity of aluminum has been shown to vary widely with water hardness and pH (Ingersoll et al., 1990a 1990b; Woodward et al., 1989; Sadler and Lynam, 1988; and Cleveland et al. 1986; and others). The benchmarks were calculated using only tests in circumneutral water. Lowest chronic and test EC20 values for fish are from 28-day embryo-larval tests with Pimephales promelas. Kimball (n.d.) presented a CV of $5800 \mathrm{ug} / \mathrm{L}$, however, after further analysis the EPA (1988) offered another value of $3288 \mathrm{ug} / \mathrm{L}$ as the $\mathrm{CV}$ for aluminum. Lowest chronic and test EC20 values for daphnids are from McCauley et al. (1986). The EPA (1988) gives a 4-day test EC50 for Selenastrum capricornutum which is used as the plant chronic value.

Ammonia. The test EC20 value for fish is from an embryo-larval test with fathead minnows (Thurston et al. 1986). The chronic value for fish is from an early life stage test with pink salmon, Oncorhynchus gorbuscha (Rice and Bailey 1980). The chronic value for daphnids is from EPA (1985a). Chronic values were determined using Daphnia magna in life-cycle tests. EPA (1985a) provided the chronic value for aquatic plants, in which Chlorella vulgaris experienced growth inhibition (EC50). The NAWQC for ammonia are functions of temperature (T) and pH. The acute NAWQC for ammonia is $0.52 / \mathrm{FT} / \mathrm{FPH} / 2$, and the chronic NAWQC for ammonia is 0.80/FT/FPH/Ratio, where:

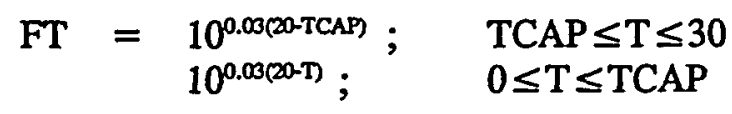




$$
\begin{aligned}
& \mathrm{FPH}=1 ; \quad 8 \leq \mathrm{pH} \leq 9 \\
& 1+10^{7.4 \mathrm{pH}} ; \quad 6.5 \leq \mathrm{pH} \leq 8 \\
& 1.25 \\
& \text { Ratio }=16 ; \quad \cdot \quad 7.7 \leq \mathrm{pH} \leq 9 \\
& =(24) \frac{10^{7.7-\mathrm{pH}}}{1+10^{7.4 \mathrm{pH}}} ; \quad 6.5 \leq \mathrm{pH} \leq 7.7
\end{aligned}
$$

$\mathrm{TCAP}=20^{\circ} \mathrm{C}$ for acute criteria and $15^{\circ} \mathrm{C}$ for chronic criteria when Salmonids or other sensitive cold water species are present

$=25^{\circ} \mathrm{C}$ for acute criteria and $20^{\circ} \mathrm{C}$ for chronic criteria when Salmonids and other sensitive coldwater species are absent

These criteria are presented in greater detail in EPA (1985a and 1986b).

Antimony. Chronic and test EC20 values for antimony are from Kimball (n.d.). The chronic tests of Pimiphales promelas were embryo-larval, and 28-day test LC50s were used for Daphnia magna. The EPA (1978) gives a 4-day EC50 for chlorophyll A inhibition in Selenastrum capricornutum which is used as the plant value. The SAV and SCV listed in this report are lower than the acute and chronic LOEL values listed in the Water Quality Criteria Summary (EPA 1986b).

Arsenic III. NAWQC are listed for arsenic III. The lowest chronic values for fish and daphnids are given by Call et al. (1983) and Lima et al. (1984). Early life stage tests were used on Pimiphales promelas and life-cycle tests were used on Daphnia magna. Cowell (1965) provides the lowest chronic value for the algae Spirogyra, Cladophora, and Zygnema which is a concentration that produced a $100 \%$ kill in 2 weeks. The test EC20 values are derived from Lima et al. (1984) for fish and from Call et al. (1983) and Lima et al. (1984) for daphnids.

Arsenic V. The chronic and test EC20 values for fish are from an early life stage test with Pimephales promelas (Defoe 1982), and the test EC20 for daphnids is from Spehar et al. (1980). The estimated chronic value for daphnids was calculated with a Daphnia magna LC50 from EPA (1985b) using Equation (3). Vocke (1980) provides the plant value from a 14-day EC50 test with Scenedesmus obliquus.

Barium. The chronic value for daphnids is from a 21-day test on Daphnia magna by Biesinger and Christensen (1972) which resulted in 16\% reproductive impairment.

Beryllium. The chronic and test EC20 values for Daphnia magna are from a life-cycle test in Kimball (n.d.). Karlander and Krauss (1972) provide the plant value for Chlorella vannieli, a 10 to $20 \%$ reduction in autotrophic growth rates. The estimated chronic and test EC20 values for fish were derived using data for Pimephales promelas from EPA (1980f) in Equations (1) and (5). The derived SCV listed in this report is lower than the lowest CV listed in the Water Quality Criteria Summary (EPA 1986b).

Boron. The EC20 value for daphnids was based on a 21-day test on Daphnia magna by 
Gerisch (1984). A 21-day test of Daphnia magna by Lewis and Valentine (1981) provided the lowest daphnid chronic value.

Cadmium. The NAWQC for cadmium are functions of water hardness. The equations for

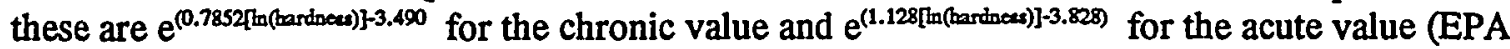
1986b). The lowest chronic value for fish is from Sauter et al. (1976) and Chapman et al. (n.d.) for daphnids. Early life stage tests were performed on brook trout, and life-cycle tests were performed on Daphnia magna. The test EC20 values are from Carlson et al. (1982) for fish and Elnabarawy et al. (1986) for daphnids. The value for aquatic plants is from Conway (1977). A relatively low cadmium concentration reduced the population growth rate of Asterionella formosa by an order of magnitude.

Calcium. The chronic value for daphnids is a concentration causing a $16 \%$ reduction in reproduction of Daphnia magna exposed to $\mathrm{CaCl}_{2} \bullet 2 \mathrm{H}_{2} \mathrm{O}$ (Biesinger and Christensen 1972). Because the highly conservative secondary values were below commonly occurring ambient concentrations of this macronutrient, they were judged to be inappropriate and are not presented.

Chromium III. The NAWQC for chromium III are functions of water hardness. The

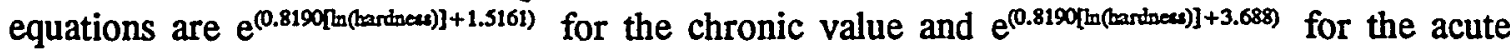
value. The lowest chronic value for fish is from an early life stage test by Stevens and Chapman (1984) on rainbow trout. Chapman et al. (n.d.) provide a chronic value from a life-cycle test of Daphnia magna. The plant value for chromium III is from a 4-day chronic test in which there was a 50\% inhibition of growth of Selenastrum capricornutum (EPA 1985c). Stevens and Chapman (1984) also provided data for the test EC20 value for fish.

Chromium VI. There are NAWQC for chromium VI. The chronic and test EC20 values for fish are from Sauter et al. (1976). An early life stage test produced the chronic value for rainbow trout. For daphnids, a life-cycle chronic test was run by Mount (1982) on Daphnia magna, and the test EC20 is from Elnabarawy et al. (1986). Microcystis aeruginosa, used for the aquatic plant value, showed incipient inhibition in tests reported by the EPA (1985c).

Cobalt. The chronic and test EC20 values for cobalt are from Kimball (n.d.). Daphnia magna were used in 28-day life-cycle tests, and Pimiphales promelas were used in embryo-larval tests.

Copper. The NAWQC for copper are functions of water hardness. The equations are

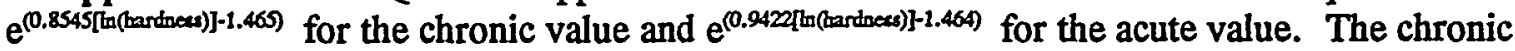
and test EC20 values for fish are from an early life stage test with brook trout by Sauter et al. (1976). The chronic and test EC20 values for daphnids are from Dave (1984a). A 21-day test LC50 on Daphnia magna provided the chronic value for daphnids. Arthur and Leonard (1970) provided a chronic value through 6-week tests on the amphipod, Gammarus pseudolimnaeus. Steeman-Nielsen and Wium-Anderson (1970) provide a plant value based on a lag in growth of the alga, Chlorella pyrenoidosa.

Cyanide. There are NAWQC for cyanide. The chronic and test EC20 values for fish were both from a brook trout life-cycle test by Koenst et al. (1977). Oseid and Smith (1979) provide full life-cycle test on Gammarus pseudolimnaeus, an amphipod. The alga, Scenedesmus 
quadricauda, showed incipient inhibition in chronic tests by the EPA (1985e).

Fluoride ion. Chronic and test EC20 values for daphnids are from Dave (1984b). The chronic value and test $E C 20$ for fish are estimates based on an $\mathrm{LC}_{50}$ from AQUIRE for brown trout using Equations (2) and (5).

Iron. The NAWQC for iron is based on a field study at a site receiving acid mine drainage and is not consistent with the current method for deriving criteria. The lowest chronic value for daphnids $(158 \mu \mathrm{g} / \mathrm{L})$ is a threshold for reproductive effects from a 21-day test of $\mathrm{FeCl}_{2}$ with Daphnia magna (Dave 1984c). It is considerably lower than the $4380 \mu \mathrm{g} / \mathrm{L}$ concentration causing $16 \%$ reproductive decrement in another test of $\mathrm{FeCl}_{2}$ with $D$. magna (Biesinger and Christensen 1972). Dave (1984c) argued that his result was more applicable to a situation in which "an acidic iron-containing waste water is discharged into a lake or a river" where it is neutralized, but Biesinger and Christensen's (1972) result "is probably more close to the steady-state situation in natural freshwater without any point source of iron." The lowest chronic value for fish is a concentration that caused $100 \%$ larval mortality in an embryo-larval test with rainbow trout exposed to dissolved iron salts (Amelung 1981).

Lead. The NAWQC for lead are functions of water hardness. The equations are $\mathrm{e}^{(1.273[\mathrm{~h}(\mathrm{hardne} s)]-}$ 4.705) for the chronic value and $\mathrm{e}^{(1.273[\mathrm{~h}(\text { (bardeces)]-1.450) }}$ for the acute value. The lowest chronic value for fish was provided by an early life stage test on rainbow trout by Davies et al. (1976). Daphnia magna were used in 21-day tests to determine lowest chronic toxicity by Chapman et al. (manuscript). Borgmann et al. (1978) provided a chronic value for a life-cycle test on Lymnaea palastris, a snail. Chlorella vulgaris, Scenedesmus quadricauda, and Selenastrum capricornutum experienced $53 \%, 35 \%$, and $52 \%$ growth inhibition, respectively, at the plant chronic value (EPA 1985f). The test EC20 value for fish is from Sauter et al. (1976). The acute-EC20 ratio from which the SS test EC20 was calculated had to be obtained using a species mean acute value for Salmo gairdneri (EPA 1985f) since no acute value was reported by Sauter et al. (1976).

Magnesium. The chronic value for daphnids is a concentration causing a $16 \%$ reduction in reproduction of Daphnia magna exposed to $\mathrm{MgCl}_{2} \cdot 6 \mathrm{H}_{2} \mathrm{O}$ (Biesinger and Christensen 1972). Because the highly conservative secondary values were below commonly occurring ambient concentrations of this nutrient element, they were judged to be inappropriate and are not presented.

Manganese. All chronic and test EC20 values for manganese are from Kimball (n.d.). The fish chronic value is from a 28-day early life-stage test with Pimephales promelas. Daphnia magna were used in 28-day LC50 tests.

Mercury, inorganic, or total. Mercury has NAWQC. However, the chronic criterion for mercury is based on the final residue value derived from a methyl mercury bioconcentration factor. To protect aquatic life, the secondary values were derived from the EPA's (1985f) final acute and chronic values. The chronic and test EC20 values for fish are from Call et al. (1983), and those for daphnids are from Biesinger et al. (1982). The chronic tests for fish were run on Pimiphales promeles throughout their embryo-larval stage. Daphnia magna were used in flow through life-cycle tests. The plant value is for incipient inhibition of Microcystis aeruginosa in 
an 8-day test (EPA 1985f). The acute-EC20 ratio used to calculate the SS test $\mathrm{EC}_{20}$ value had to be derived using a species mean acute value (EPA 1985g) since no acute value was reported in Biesinger et al. (1982).

Mercury, methyl. The chronic and test EC20 values for fish are from McKim et al. (1976). Brook trout were used in three generation life-cycle tests. The chronic and test EC20 values for daphnids are from Biesinger et al. (1982). Daphnia magna were used in flow through life-cycle tests. The alga, Chlorella vulgaris, was used in 15-day EC50 (growth) tests by Rai et al. (1981) to determine chronic toxicity values for aquatic plants.

Molybdenum. The chronic and test EC20 values for daphnids are from Kimball (n.d.). Daphnia magna were used in a 28-day life-cycle test to determine the chronic value.

Nickel. The NAWQC for nickel are functions of water hardness. The equation for these are

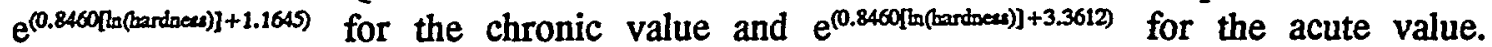
However, nickel concentrations of $10 \mathrm{ug} / \mathrm{L}$ in Oak Ridge Reservation stream water (considerably below the chronic NAWQC for nickel but similar to the lowest of the alternate benchmarks) reduced 7-day Ceriodaphnia dubia survivorship to 60\% (Kszos et al. 1992). The chronic and test EC20 values for fish are from Nebeker et al. (1985). The chronic value for fish was determined through an early life stage test on rainbow trout. For daphnids, the chronic value was from Lazareva (1985) and the test EC20 was from Münzinger (1990). Daphnia magna were used in a life-cycle test to determine the chronic value. The caddisfly, Clistoronia magnifica, was used in life-cycle tests by Nebeker et al. (1984) to determine the chronic value. The plant chronic toxicity values were provided by the EPA (1986a) for Microcystis aeruginosa, which showed incipient inhibition.

Potassium. The chronic value for daphnids is a concentration causing a $16 \%$ reduction in reproduction of Daphnia magna exposed to $\mathrm{KCl}$ (Biesinger and Christensen 1972). Because the highly conservative secondary values were below commonly occurring ambient concentrations of this macronutrient, they were judged to be inappropriate and are not presented.

Selenium. NAWQC are listed for selenium. The chronic and test EC20 values for fish are from Goettl and Davies (1976). Their tests were during the early life stage of rainbow trout. The chronic value for daphnids is from Kimball (n.d.), and the test EC20 is from Johnston (1987). These tests were run for 28 days on Daphnia magna. The green alga, Scenedesmus obliquus, exhibited reduced growth in the 14-day chronic toxicity tests (Vocke et al. 1980). The acute-EC20 ratio used in calculation of the SS EC20 value had to be derived using a species mean acute value for Daphnia magna (EPA 1987a) because no acute value was reported by Johnston.

Silver. The acute NAWQC for silver, which is a function of water hardness, is given by the

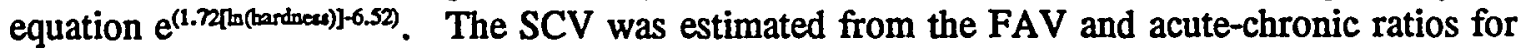
three species. Although questions about two of these ratios prompted the EPA to refrain from calculating a final chronic value, we judged them to be better than the default value. The lowest chronic value for fish is based on an early life stage test on rainbow trout by Davies et al. (1978). The lowest chronic value for daphnids and the test EC20 for fish are from Nebeker et al. (1983). The daphnid CV is from a test with Daphnia magna. The test EC20 for daphnids is from 
Elnabarawy et al. (1986). The plant value is for growth inhibition in Chlorella vulgaris (EPA 1980y).

Sodium. The chronic value for daphnids is a concentration causing a $16 \%$ reduction in reproduction of Daphnia magna exposed to $\mathrm{NaCl}$ (Biesinger and Christensen 1972). Because the highly conservative secondary values were below commonly occurring ambient concentrations of this macronutrient, they were judged to be inappropriate and are not presented.

Strontium. The chronic value for daphnids is from 21-day tests on Daphnia magna by Biesinger and Christensen (1972) which resulted in 16\% reproductive impairment.

Thallium. Chronic and test EC20 values are from Kimball (n.d.). Embryo-larval tests were run on Pimephales promelas, and 28-day test LC50s were run on Daphnia magna. The aquatic plant value is a 4-day EC50 which reduced the cell numbers of the alga, Selenastrum capricornutum (EPA 1978);

Tin. The chronic value is from Biesinger and Christensen (1972). It caused $16 \%$ reproductive impairment in Daphnia magna in 21 days.

Uranium. The chronic value for fish is an estimate based on a fathead minnow LC50 from Cushman et al. (1977) used in Equation (1). The test EC20 is an estimate based on the same data; however, Equation (5) was used.

Vanadium. The lowest chronic and test EC20 values for fish are from Holdway and Sprague (1979) and for daphnids from Kimball (n.d.). A 96-day life-cycle test was used on the flagfish, Jordanella floridae. A 28-day life-cycle test was completed using Daphnia magna.

Zinc. The NAWQC for zinc are functions of water hardness. The equations are

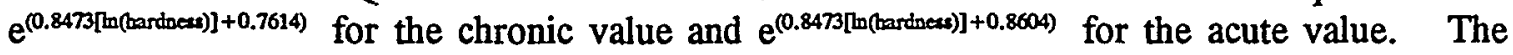
chronic and test EC20 values for fish are from Spehar (1976), and the chronic value for daphnids is from Chapman et al. (n.d.). Life-cycle tests were run on Jordanella floridae and Daphnia magna. Nebeker et al. (1984) provided chronic values from life-cycle tests on the caddisfly, Clistoronia magnifica. Bartlett et al. (1974) ran 7-day tests on Selenastrum capricornutum. These aquatic plants showed incipient inhibition of growth.

Zirconium. The chronic and test EC20 values for fish are estimates based on an LC50 for Pimephales promelas from Cushman et al. (1977). These values were calculated using Equations (1) and (5).

\subsection{ORGANICS}

Acenaphthene. Although the full data requirements are not met for acenaphthene, the EPA has presented final acute and chronic values for derivation of sediment quality criteria which are presented in the criteria columns (EPA 1993b). The fish chronic value is from an early life-stage test with Pimephales promelas, and the non-daphnid chronic value is from a life-cycle test with a midge Paratanytarsus sp. (EPA 1993b). The plant value is from EPA (1978). Selenastrum 
capricornutum were used in 96-hour EC50 (50\% reduction in cell numbers).

Acetone. The chronic and test EC20 values for fish and daphnids are estimates based on an LC50 for rainbow trout and the genus mean EC50 for Daphnia from AQUIRE used in Equations (2),(4), and (5).

Anthracene. The chronic value for daphnids (Daphnia magna) was estimated using an EC50 from Holst and Giesy (1989). The chronic and test EC20 values for fish are an estimate based on an LC50 for bluegill from Oris and Giesy (1985). Calculations were performed using Equations (2), (4), and (5).

Benzene. The lowest chronic value for daphnids is given by EPA (1978). Daphnia magna were used in life-cycle tests. The lowest chronic value for aquatic plants is given by Kauss and Hutchinson (1975), which was a 48-hour test EC50 on Chlorella vulgaris. The chronic value for fish is an estimate based on data for the rainbow trout from EPA (1980d) and Equation (2). The test EC20 value for fish is derived from Black and Birge (1982). The reader should note that Black and Birge conducted a series of screening tests for a large number of chemicals on several freshwater organisms. Larval fish survival was recorded to only 4 days post-hatch, and LOECs and NOECs were not determined. These tests, then, did not generate standard chronic values and are not equivalent to the other chronic tests cited in this report. The test EC20 values based on tests by Black and Birge may be high relative to those from conventional chronic tests.

Benzidene. The chronic and EC20 value for fish are an estimate based on data for red shiner from EPA (1980c). Calculations were performed using Equations (2) and (5).

Benzo(a)anthracene. The chronic value for daphnids is an estimate based on data for Daphnia magna from Trucco et al. (1983) used in Equation (4).

Benzo(a)pyrene. The test EC20 for fish is derived from Hannah et al. (1982). The chronic value for daphnids is an estimate based on data for Daphnia magna from Trucco et al. (1985) used in Equation (4).

Benzoic Acid. The chronic value for fish is an estimate based on data for the mosquitofish from AQUIRE used in Equation (2). The estimated test EC20 for fish is based on the same data, but Equation (5) was used.

Benzyl Alcohol. The chronic and test EC20 values for fish are estimates based on data for bluegill from Dawson et al. (1977). The calculations were performed using Equations (2) and (5).

BHC (lindane). There are NAWQC for lindane. The chronic values for daphnids, fish, and non-daphnid invertebrates are all from Macek et al. (1976a). The test EC20 values for daphnids and fish are also from Macek et al. (1976a). The chronic values were derived from life-cycle tests run on Pimephales promelas, Daphnia magna, and the midge Chironimus tentans. The chronic value for aquatic plants is from Krishnakumari (1977); Scenedesmus acutus exhibited $20 \%$ growth inhibition in 5 days. The acute-EC20 ratio from which the SS EC20 was calculated was derived using a species mean acute value for Salvelinus fontinalis (EPA 1980s) since no acute data were reported by Macek et al. (1976a). 
BHC (other). The chronic value for daphnids was estimated using a Daphnia magna EC50 from AQUIRE in Equation (4).

Bis(2-ethylhexyl)phthalate. The chronic and test EC20 values for fish are from a rainbow trout early life-stage test (Mehrle and Mayer 1976). The lowest chronic value for daphnids is from a 21-day test with Daphnia magna (Knowles et al. 1987). A much lower value was reported in the previous edition of this report, but the results of that study are now believed to be incorrect (Knowles et al. 1987). The new value is supported by a CV of $912 \mu \mathrm{g} / \mathrm{L}$ from Adams and Heidolph (1985). That study is used in the derivation of the SCV because, unlike the Knowles et al. (1987) study, it has an accompanying acute value (48-hr EC50). No test EC20 for daphnids was calculated because insufficient detail was presented by Adams and Heidolph (1985) and Knowles et al. (1987).

2-Butanone. The chronic values for fish and daphnids are estimates based on data from Veith et al. (1983) and Randall and Knopp (1980), respectively. Equation (4) was applied to the data for Daphnia magna, and Equation (2) was applied to the data for Pimephales promelas. The test EC20 value for fish is also an estimate using Equation (5) and an LC50 from Veith et al. (1983).

Carbon disulfide. The chronic and test EC20 values for fish are estimates based on data for mosquitofish from AQUIRE using equations (2) and (5). The chronic value for daphnids is an estimate for Daphnia magna using data from Van Leeuwen (1985) in Equation (4).

Carbon tetrachloride. The chronic value for fish is a rainbow trout embryo-larval LC50 (Black and Birge 1982); therefore, it may be too high. However, it is lower than values presented by Kimball et al. (n.d.) and EPA (1980h) for fathead minnows. The same test was used to derive the test EC20 for fish (see the comments on benzene). The chronic value for daphnids is from a 7-day reproduction test with Daphnia magna (Kimball et al. n.d.). None of the subchronic tests could be used in the calculation of the SCV.

Chlordane. The chronic NAWQC for chlordane is based on the final residue value. For a criterion to protect aquatic life rather than its use, the FCV is reported. The lowest chronic and test EC20 values are derived from Daphnia magna, bluegill, and Chironomus tentans life-cycle tests (Cardwell et al. 1977).

Chlorobenzene. The chronic values for fish and daphnids are estimates based on data for bluegill and Daphnia magna from EPA (1980j). The values were calculated using Equations (2) and (4). The plant value is a 96-hour EC50 for cell number with Selenastrum capricornutum (EPA 1980j).

Chloroform. The test EC20 value for fish is from Black and Birge (1982). (Refer to the section on benzene). The chronic value is a 27-day LC50 for rainbow trout (embryo-larval) from EPA (1980l). The EPA (1986b) gives this value as a lowest observed effect value in lieu of a NAWQC. The chronic value for daphnids is an estimate based on data for Daphnia magna from EPA (1980l) and calculated from Equation (4).

DDD. The chronic and EC20 values for fish are estimates based on data for largemouth bass from Mayer and Ellersieck (1986) and are calculated using Equations (2) and (5). 
DDT. The acute NAWQC for DDT is used. The chronic NAWQC, however, is not used because it is based on the final residue value. To protect aquatic life, an SCV is presented. The test EC20 value for fish is derived from Jarvinen et al. (1977). The fish chronic value is from a Pimephales promelas life-cycle test (EPA 1980m). The chronic value for daphnids is an estimate based on data for Daphnia pulex from EPA (1980m) and calculated with Equation (4). The aquatic plant chronic value is from Sodergreen (1968). Chlorella vulgaris was affected in growth and morphology.

Decane. The chronic value for daphnids is an estimate based on data for Daphnia magna from Le Blanc (1980) used in Equation (4).

Di-n-butyl phthalate. All chronic and test EC20 values are from McCarthy and Whitmore (1985). The chronic value for daphnids is based on the geometric means of the observed concentration of fresh solutions and aged solutions. Daphnia magna were used in life-cycle tests, and Pimiphales promelas were used in early life stage tests.

Dibenzofuran. The chronic value for daphnids is an estimate based on data for Daphnia magna from AQUIRE and used in Equation (4).

1,1-Dichloroethane. The chronic and test EC20 values for fish are estimates based on an LC50 for guppy from Koneman (1981) and calculated using Equations (2) and (5).

1,2-Dichloroethane. The chronic value for fish is from Ahmed et al. (1984). Early life stage tests were conducted on Pimephales promelas. The test EC20 value for fish is from Benoit et al. (1982). The chronic and test EC20 values for daphnids are from Daphnia magna 28-day life-cycle tests (Richter et al. 1983).

1,1-Dichloroethene. The chronic values for fish and aquatic plants are from EPA (1978). Pimephales promelas were used in embryo-larval tests. The alga, Selenastrum capricornutum, was used in a 96-hour EC50 where it exhibited loss of chlorophyll A and cell numbers. The chronic value for daphnids is an estimate based on data for Daphnia magna from EPA (1980n) used in Equation (4).

1,2-Dichloroethene. The chronic and test EC20 values for fish are estimates based on data for bluegill from EPA (1980n). These values were derived using Equations (2) and (5).

1,3-Dichloropropene. The test EC20 for fish was estimated using an LC50 for bluegill from EPA (19800) in Equation (5). The chronic values for fish and aquatic plants are from EPA (1978). Pimephales promelas were used in an embryo-larval test, and Selenastrum capricornutum were used in a 96-hour EC50. The alga showed chlorophyll A and cell loss. The chronic value for daphnids was estimated using an EC50 for Daphnia magna from EPA (19800) in Equation (4).

Diethyl phthalate. The plant value is a 96-hour EC50 for Selenastrum capricornutum (EPA 1978).

Di-n-octyl phthalate. All chronic and test EC20 values are from McCarthy and Whitmore 
(1985). Chronic values were based on Pimephales promelas in early life stage tests and Daphnia magna in life-cycle tests. There are no Tier II values for di-n-octyl phthalate because LC50s were not available.

Ethyl benzene. The chronic value for fish is from Pimephales promelas embryo-larval tests (EPA 1978). The chronic value for aquatic plants is from EPA (1978). Selenastrum capricornutum displayed chlorophyll A inhibition in 96-hour EC50. The chronic value for daphnids was estimated using an EC50 for Daphnia magna from EPA (1980p) in Equation (4).

Fluoranthene. Although the full data requirements are not met for fluoranthene, the EPA (1993c) has derived an FAV and FCV as a part of the derivation of sediment quality criteria which are presented in Table 1. The fish CV is from an early life-stage test with Pimephales promelas, and the daphnid CV is from a life-cycle test with Daphnia magna EPA (1993c).

Heptachlor. The acute NAWQC for heptachlor is used. Because the chronic NAWQC is based on the final residue value, an SCV is reported herein. The chronic and test EC20 values for fish are from Macek et al. (1976b). Pimephales promelas were used in life-cycle tests to determine the chronic value for fish. The SS test EC20 value was calculated using an acute-EC20 ratio that was derived from a species mean acute value for Pimephales promelas (EPA 1980r) because no acute data are available from Macek et al. (1976b). The chronic value for aquatic plants is from EPA (1980r). Growth inhibition was exhibited by Selenastrum capricornutum in 96-hour EC50. The chronic value for daphnids is an estimate based on data for Daphnia pulex from EPA (1980r) using Equation (4).

Hexane. The chronic value and test EC20 value for fish are estimates based on LC50s for golden orfe from AQUIRE and calculated using Equations (2) and (5).

2-Hexanone. The chronic value and test EC20 value are estimates based on an LC50 for Pimephales promelas from AQUIRE and calculated using Equations (2) and (5).

1-Methylnaphthalene. The chronic and test EC20 values for fish are estimates based on data for Pimiphales promelas from AQUIRE. The values were calculated with Equations (2) and (5).

4-Methyl-2-pentanone. The chronic value for fish is from Call et al. (1985). Pimephales promelas embryos, larva, and juveniles were exposed for 31 to 33 days.

2-Methylphenol. The chronic value for daphnids is an estimate based on data for Daphnia magna from Adema (1978) and Canton and Adema (1978). The value was calculated using Equation (4). The chronic and test EC20 values for fish were estimated using an LC50 for rainbow trout from DeGraeve et al. (1980) in Equations (2) and (5).

Methylene chloride. The chronic value for fish is from Dill et al. (1987). Pimephales promelas were used in 32-day embryo-larval tests. The chronic value for daphnids is an estimate based on data for Daphnia magna from LeBlanc (1980) used in Equation (4). The test EC20 value for fish is from Black and Birge (1982). (Refer to the section on benzene concerning data from this source.) 
Naphthalene. The chronic and test EC20 values for fish are from DeGraeve et al. (1982), and the test EC20 value for daphnids is from Geiger and Buikema (1982). Pimphales promelas were used in embryo-larval tests to determine chronic toxicity. The chronic value for aquatic plants is from EPA (1980t). The alga, Chlorella vulgaris, exhibited inhibited cell numbers in 48-hour EC50. The chronic value for daphnids is an estimate based on data for Daphnia magna from EPA (1980t) used in Equation (4).

4-Nitrophenol. The chronic and test EC20 values for daphnids are from Francis et al. (1986). The chronic and test EC20 values for fish are estimates based on data for bluegill from Buccafusco et al. (1981) and used with Equations (2) and (5). The EPA (1978) is the source for the chronic value for aquatic plants. Selenastrum capricornutum exhibited chlorophyll A reduction in 96-hour EC50.

$\mathrm{N}$-nitrosodiphenylamine. The source for the estimated fish and daphnid chronic values are Buccafusco et al. (1981) and LeBlanc (1980), respectively. Equation (2) was used to calculate the estimated fish (bluegill) value, and Equation (4) was used for the estimated daphnid (Daphnia magna) value. The test EC20 value for fish is also an estimate. Buccafusco et al. (1981) provided the LC50 for bluegill used with Equation (5) to estimate the EC20.

3-Octanone. The chronic values for fish and daphnids are estimated from data for goldfish and Daphnia magna from AQUIRE and calculated using Equations (2) and (4). The test EC20 for fish was estimated using Equation (5) and an LC50 for goldfish from AQUIRE.

PCBs: Total. There are NAWQC for PCBs, but the chronic criterion is based on the final residue value. Since that value is intended to protect the use of aquatic life, an SCV is calculated to protect the aquatic life itself. The fish lowest chronic value and test EC20 are from a full life-cycle test of fathead minnows by Defoe (1978). The lowest chronic value and test EC20 for daphnids are from a 2-week continuous flow test with Daphnia magna (Nebeker and Puglisi 1974). The lowest chronic value for non-daphnid invertebrates is from a 3-week LC50 for Tanytarsis dissimilis by Nedeker and Puglisi (1974). The lowest plant value is for reduction in carbon fixation by Scenedesmus quadricaudata in a 24-hour test (Laird 1973).

PCBs: Aroclor ${ }^{\circ}$ 1221. The chronic and test EC20 fish values are estimates based on data for cutthroat trout by Stalling and Mayer (1972). Equations (2) and (5) were used to determine the EC20 value for fish. The chronic value for aquatic plants is a 48-hour LC50 for Euglena gracilis (Ewald et al. 1976).

PCBs: Aroclor ${ }^{\circ}$ 1232. The chronic and test EC20 fish values are estimates based on data for cutthroat trout by Stalling and Mayer (1972) and AQUIRE. The geometric mean was derived from these two values and then placed into Equations (2) and (5).

PCBs: Aroclor 1242. The chronic and test EC20 values for fish are from Nebeker et al. (1974). Pimephales promelas were used in full life-cycle tests. The chronic values for nondaphnid invertebrates are from Nebeker and Puglisi (1974). Gammarus pseudolimnaeus were exposed to PCBs for 2 months in a continuous-flow system. The chronic value for aquatic plants is a 24-hour test in which Scenedesmus obtusiusculus showed growth inhibition (Larsson and Tillberg 1975). 
PCBs: Aroclor ${ }^{\circ}$ 1248. The chronic and test EC20 values for fish are from DeFoe et al. (1978), and the chronic and test EC20 values for daphnids are from Nebeker and Puglisi (1974). The chronic values for fish were full life-cycle tests carried out on Pimephales promelas. The chronic value for daphnids was determined through 3-week exposures that created a $16 \%$ reproductive impairment in Daphnia magna. The chronic value for a non-daphnid invertebrate is from Nebeker and Puglisi (1974). Gammarus pseudolimnaeus was exposed for 2 months.

PCBs: Aroclor ${ }^{\circ}$ 1254. The chronic value for fish is from a brook trout life-cycle test (Mauck et al. 1978), and the test EC20 value is from a fathead minnow life-cycle test (Nebeker et al. 1974). The chronic and test EC20 values for daphnids are from Nebeker and Puglisi (1974). Daphnia magna were exposed for 2 weeks in a continuous-flow environment. The lowest chronic value for nondaphnid invertebrates is from a 3-week LC50 for Tanytarsis dissimilis by Nedeker and Puglisi (1974). The lowest plant value is for reduction in carbon fixation by Scenedesmus quadricaudata in a 24-hour test (Laird 1973).

PCBs: Aroclor ${ }^{\circ}$ 1260. The chronic and test EC20 values for fish are from DeFoe et al. (1978). The chronic value is ambiguous because significant effects occurred at the lowest concentration tested in a 30-day fathead minnow larval test at the lowest concentrations tested $(1.3 \mu \mathrm{g} / \mathrm{L})$ but not in a 240-day lifecycle at the highest concentration tested $(2.1 \mu \mathrm{g} / \mathrm{L})$.

1-Pentanol. The chronic and test EC20 values for fish are estimates based on data for rainbow trout from AQUIRE and calculated using Equations (2) and (5).

Phenanthrene. The chronic and test EC20 values for daphnids are from Geiger and Buikema (1982). The chronic value was determined using Daphnia pulex in full life-cycle tests.

Phenol. The chronic and test EC20 values for fish are from fathead minnow embryo-larval tests (DeGraeve et al. 1980). The chronic value for daphnids is an estimate based on data for Daphnia longispina from EPA (1980v) and calculated using Equation (4). The chronic value for aquatic plants is from Reynolds (1975). Selenastrum capricornutum exhibited $60 \%$ reduction in cell numbers and $12 \%$ growth inhibition.

2-Propanol. The chronic and test EC20 values for fish are estimates based on data for Pimephales promelas from AQUIRE and Veith et al. (1983). The geometric mean of these LC50s was used in Equations (2) and (4).

1,1,2,2-Tetrachloroethane. The chronic and test EC20 values for fish are from Ahmed et al. (1984), and the values for daphnids are from Richter et al. (1983). The chronic values for fish were derived from embryo-larval tests on Pimephales promelas. The chronic values for daphnids were derived from 28-day tests run on Daphnia magna. The chronic value for aquatic plants is from EPA (1978). Selenastrum capricornutum exhibited chlorophyll A inhibition in 96-hour EC50.

Tetrachloroethene. The chronic value for fish is an embryo-larval test on fathead minnows (EPA 1980aa). The test EC20 value for fish is from Ahmed et al. (1984). The chronic and test EC20 values for daphnids are from Richter et al. (1983). These were 28-day tests on Daphnia magna. The plant value is from EPA (1978). Selenastrum capricornutum decreased in cell 
number and chlorophyll A during the 96-hour EC50.

Toluene. The chronic values for fish and daphnids are estimates based on data for bluegill and Daphnia magna from EPA (1980cc) and calculated using Equations (2) and (4), respectively. The test EC20 value for fish is from Black and Birge (1982). (Refer to the section on benzene.) Chlorella vulgaris was used in 10-day tests by Kauss and Hutchinson (1975) to determine the chronic value for aquatic plants.

1,1,1-Trichloroethane. The chronic and test EC20 values for daphnids are from Thompson and Carmichael (1989). Daphnia magna were used in 17-day chronic tests. The chronic value and test EC20 for fish were estimated based on data for Pimephales promelas from Alexander et al. (1978) and calculated using Equation (2). The chronic value for aquatic plants is from EPA (1978). Selenastrum capricornutum decreased in chlorophyll $A$ and cell numbers in the 96-hour EC50.

1,1,2-Trichloroethane. The chronic value and test EC20 values for fish are from Ahmed et al. (1984) and the chronic and test EC20 values for daphnids are from Richter et al. (1983). The chronic value for fish is based on 32-day embryo-larval tests on Pimiphales promelas, while the chronic value for daphnids is based on 28-day tests on Daphnia magna.

Trichloroethene. The chronic and test EC20 values for fish are from Smith et al. (1991). Jordanella floridae, the flagfish, was used in 28-day embryo-larval tests. The chronic value for daphnids is an estimate based on data for Daphnia pulex from EPA (1980dd) and calculated using Equation (4).

Vinyl acetate. The chronic and test EC20 values for fish are estimates based on an LC50 for Pimephales promelas from AQUIRE calculated using Equations (2) and (5).

Vingl chloride. The chronic and test EC20 values for fish are estimates based on an LC50 for golden orfe from AQUIRE using Equations (2) and (5).

Xylene. The chronic value for fish is an estimate based on an LC50 for common carp from AQUIRE and calculated using Equation (2). The test EC20 value for fish is from Black and Birge (1982). (Refer to the section on benzene.)

\section{COMPARISON OF BENCHMARKS}

Chronic NAWQC for protection of aquatic life are available for only 16 of the 96 chemicals associated with the DOE sites and are the lowest benchmarks for only $19 \%$ of those chemicals (Table 3). This result was expected, given the characteristics of the criteria discussed previously. At the other extreme, the SCVs were lowest in $78 \%$ of the chemicals they were calculated for (i.e., chemicals with some standard data but no NAWQC). This conservatism was not surprising given the goal of the method of ensuring with $80 \%$ confidence that these values would not exceed the NAWQC. Because the relative conservatism of the Tier II values declines with the number of acute and chronic test data that were used to calculate them, the numbers of data used to calculate each value are listed in Table 4 as an indication of their conservatism. 
The other potential lower screening benchmarks are intermediate in their conservatism. In general, benchmarks based on effects on fish are less conservative than those based on daphnids or than the NAWQC which include daphnids. On average, lowest CVs for fish are more than twice the NAWQC while lowest CVs for daphnids are approximately half (Table 3 ). This result is consistent with other studies (Stephan and Erickson n.d., Suter 1993). Estimated CVs and CVs for non-daphnid invertebrates and plant values were never the lowest benchmark for this set of chemicals.

The test EC20 values are lower than the CVs for the same taxa in $62.5 \%$ and $82 \%$ of cases for fish and daphnids, respectively. This result is expected given that the test EC20s integrate across life stages but the CVs do not.

The SS test EC20 values are conservative but can be calculated for only 17 chemicals because they require the same amount of data as the chronic NAWQC. These values are on average $11 \%$ of the NAWQC when both could be calculated. They are equivalent to the NAWQC but use integrative chronic test endpoints.

The fact that some CVs for fish and daphnids are lower than chronic NAWQC is surprising at first because conceptually the chronic NAWQC are estimates of CVs for sensitive species. However, the CVs are not used directly but rather are used to calculate acute-chronic ratios that are used in the criteria calculation. Unless a species that is highly sensitive in a chronic test has a high acute-chronic ratio, it will not lower the chronic NAWQC.

The relative utility of the benchmarks is determined in large part by their availability. The NAWQC and the SS test EC20 values are available for relatively few of the chemicals detected on the Oak Ridge Reservation because they require large data sets. The Tier II values and the population EC20 are available for most of the chemicals because they each require only a single LC50. For the same reason, if estimated values are included, the CVs for fish and daphnids and the test EC20s for fish are available for most chemicals.

The test EC20 values differ from the other potential benchmarks in that they represent an observed and specified effect. All other benchmarks are estimates (population EC20s and estimated CVs and test EC20s), correspond to no particular effect (CVs and NAWQC), or both (SCVs). 
Table 3. Comparisons of alternative screening benchmarks for aquatic life on the basis of the number of chemicals for which each could be calculated (n), the percentage of those chemicals for which it was the lowest benchmark, and the median, minimum, and maximum ratio of each benchmark to the chronic NAWQC for the criterion chemicals. Note that the sum of percent lowest values is greater than $\mathbf{1 0 0}$ because these numbers of occurrences are different.

\begin{tabular}{|c|c|c|c|c|c|}
\hline & \multirow{2}{*}{$\mathbf{n}$} & \multirow{2}{*}{$\begin{array}{l}\text { Percent } \\
\text { Lowest }\end{array}$} & \multicolumn{3}{|c|}{ Ratio to Chronic NAWQC } \\
\hline & & & Median & Minimum & Maximum \\
\hline Chronic NAWQC & 16 & 19 & & & \\
\hline Secondary Chronic Value & 79 & 78 & & & \\
\hline \multicolumn{6}{|l|}{ Fish Chronic Value } \\
\hline Measured & 49 & 6.1 & 2.52 & 0.22 & 182.50 \\
\hline Estimated & 30 & 0 & & & \\
\hline \multicolumn{6}{|l|}{ Daphnid Chronic Value } \\
\hline Measured & 47 & 4.2 & 0.56 & 0.02 & 181.25 \\
\hline Estimated & 28 & 0 & & & \\
\hline $\begin{array}{l}\text { Non-Daphnid Invertebrate } \\
\text { Value }\end{array}$ & 10 & 0 & 6.41 & 0.5 & 147.66 \\
\hline Aquatic Plant Value & 36 & 0 & 2.38 & 0.03 & 6250 \\
\hline \multicolumn{6}{|l|}{ Fish Test EC20 } \\
\hline Measured & 47 & 13 & 1.14 & 0.39 & 54.02 \\
\hline Estimated & 29 & 0 & & & \\
\hline Daphnid Test EC20 & 37 & 8.1 & 0.70 & 0.02 & 137.50 \\
\hline SS Test EC20 & 17 & 71 & 0.11 & 0.01 & 2.94 \\
\hline Population EC20 & 69 & 8.7 & 3.02 & 0.60 & 28.73 \\
\hline
\end{tabular}


Table 4. Amount of data available and used to calculate Tier II values. Tier II values based on more data are less conservative

\begin{tabular}{|c|c|c|}
\hline Contaminants & Number of LC50s & $\begin{array}{l}\text { Number of } \\
\text { Chronic Values }\end{array}$ \\
\hline Antimony & 2 & 2 \\
\hline Arsenic V & 5 & 1 \\
\hline Barium & 1 & 0 \\
\hline Beryllium & 3 & 1 \\
\hline Boron & 1 & 1 \\
\hline Calcium & 1 & 1 \\
\hline Cobalt & 2 & 2 \\
\hline Fluorine & 4 & 2 \\
\hline Magnesium & 1 & 0 \\
\hline Manganese & 2 & 1 \\
\hline Mercury, inorganic & 8 & 2 \\
\hline Mercury, methyl & 1 & 1 \\
\hline Molybdenum & 1 & 1 \\
\hline Potassium & 1 & 0 \\
\hline Silver & 8 & 2 \\
\hline Sodium & 1 & 0 \\
\hline Strontium & 1 & 1 \\
\hline Thallium & 3 & 2 \\
\hline Tin & 1 & 1 \\
\hline Uranium & 1 & 0 \\
\hline Vanadium & 4 & 3 \\
\hline Zirconium & 2 & 0 \\
\hline Acetone & 4 & 0 \\
\hline Anthracene & 1 & 0 \\
\hline Benzene & 4 & 0 \\
\hline Benzidene & 3 & 0 \\
\hline Benzo(a)anthracene & 1 & 0 \\
\hline Benzo(a)pyrene & 1 & 0 \\
\hline Benzoic acid & 1 & 0 \\
\hline Benzyl alcohol & 2 & 0 \\
\hline BHC (other than gamma) & 1 & 0 \\
\hline Bis(2-ethylhexyl)phthalate & 4 & 2 \\
\hline 2-Butanone & 3 & 0 \\
\hline Carbon disulfide & 2 & 0 \\
\hline
\end{tabular}


33

Table 4. (continued)

\begin{tabular}{|c|c|c|}
\hline Contaminants & Number of LC50s & $\begin{array}{c}\text { Number of } \\
\text { Chronic Values }\end{array}$ \\
\hline Carbon tetrachloride & 3 & 1 \\
\hline Chlorobenzene & 3 & 0 \\
\hline Chloroform & 3 & 0 \\
\hline p,p'DDD & 7 & 0 \\
\hline DDT & 8 & 1 \\
\hline Decane & 1 & 0 \\
\hline Di-n-butyl phthalate & 5 & 2 \\
\hline Dibenzofuran & 1 & $\mathbf{0}$ \\
\hline 1,1-Dichloroethane & 1 & 0 \\
\hline 1,2-Dichloroethane & 3 & 2 \\
\hline 1,1-Dichloroethene & 3 & 0 \\
\hline 1,2-Dichloroethenes & 1 & 0 \\
\hline 1,3-Dichloropropene & 2 & 0 \\
\hline Diethyl phthalate & 2 & 0 \\
\hline Ethyl benzene & 3 & 0 \\
\hline Heptachlor & 8 & 1 \\
\hline Hexane & 1 & 0 \\
\hline 2-Hexanone & 1 & 0 \\
\hline 1-Methyl naphthalene & 1 & 0 \\
\hline 4-Methyl-2-pentanone & 1 & 1 \\
\hline 2-Methyl phenol & 4 & 0 \\
\hline Methylene chloride & 3 & 1 \\
\hline Naphthalene & 4 & 1 \\
\hline 4-Nitrophenol & 5 & 1 \\
\hline $\mathrm{N}$-nitrosodiphenylamine & 2 & 0 \\
\hline 3-Octanone & 2 & $\mathbf{0}$ \\
\hline PCBs (total) & 8 & 2 \\
\hline Aroclor 1221 & 1 & 0 \\
\hline Aroclor 1232 & 1 & $\mathbf{0}$ \\
\hline Aroclor 1242 & 3 & 2 \\
\hline Aroclor 1248 & 1 & 1 \\
\hline Aroclor 1254 & 3 & 1 \\
\hline Aroclor 1260 & 1 & 0 \\
\hline 1-Pentanol & 2 & 0 \\
\hline Phenanthrene & 2 & 0 \\
\hline
\end{tabular}


34

Table 4. (continued)

\begin{tabular}{lcc}
\hline Contaminants & Number of LC50s & $\begin{array}{c}\text { Number of } \\
\text { Chronic Values }\end{array}$ \\
\hline Phenol & 6 & 2 \\
2-Propanol & 1 & 0 \\
1,1,2,2-Tetrachloroethane & 3 & 2 \\
Tetrachloroethene & 5 & 2 \\
Toluene & 4 & 0 \\
1,1,1-Trichloroethane & 2 & 1 \\
1,1,2-Trichloroethane & 3 & 2 \\
Trichloroethene & 3 & 1 \\
Vinyl acetate & 2 & 0 \\
Vinyl chloride & 1 & 0 \\
Xylene & 2 & 0 \\
\hline
\end{tabular}

Finally, the Tier II values differ from the other benchmarks in that they are based on lower 20\% confidence bounds rather than best estimates of a threshold for significant effects. Uncertainties are not incorporated into any of the other benchmarks. However, the lower 5\% confidence bound on the population EC20 could be used as a conservative benchmark (Appendix C). Lower 5\% prediction intervals can be derived for the estimated CVs and test EC20s by subtracting the PIs listed in the text from the base 10 logs of the estimates reported in Table 1. (For all three of these equations, the variance changes negligibly with deviation from mean X.) These lower likelihood bounds were not used because the other benchmarks do not have the legal imperative of the NAWQC. However, to be certain of a conservative screen, lower bounds could be substituted for the population EC20s and estimated CVs and test EC20s listed in Tables 1 and 2.

\section{APPLICATION OF BENCHMARKS}

Use of these aquatic screening benchmarks requires that the assessor choose which benchmarks to employ and which water concentrations to apply them to. The choice of benchmarks depends on the interpretation of the benchmarks, their regulatory standing, and their degree of conservatism.

Each of the alternative benchmarks has a different interpretation. Exceedences of NAWQC create a regulatory imperative for action under the Comprehensive Environmental Response, Compensation, and Liability Act (CERCLA) because they are ARARS. Exceedence of a Tier II value implies a greater than $20 \%$ chance that the NAWQC, if their value were known, would be exceeded. Exceedence of a CV indicates that the field concentration is greater than a concentration dividing statistically insignificant from significant effects in a chronic toxicity test. Exceedence of a test EC20 indicates that biologically significant effects levels were exceeded in a chronic toxicity test. Exceedence of the SS test EC20 indicates that a biologically significant 
effect level may be exceeded in a sensitive species. Exceedence of a population EC20 indicates that a significant reduction in a largemouth bass population could occur. Therefore, exceedence of either the acute or chronic NAWQC indicates a need for action. Exceedence of an SCV implies a low risk. Exceedence of any of the other benchmarks indicates a risk of real effects that should lead to additional data collection and assessment. However, these inferences all depend on comparison of the benchmarks to appropriate water concentrations.

Contaminant screening is not a regulatory process, but managers at some sites prefer to use only values that have been approved by regulatory agencies. The NAWQC are clearly regulatory values in that they are ARARS and have been adopted by Tennessee and most other states as water quality standards. Lowest chronic values (the last column in Table 1) have been presented by the EPA in place of NAWQC (EPA 1986b), but they are not criteria. They merely indicate that the EPA believes toxic effects may occur at that concentration. The Tier II values (SAV and SCV) are proposed by the EPA as values that could be used for regulatory enforcement in the Great Lakes (EPA 1993a). They are more conceptually consistent with the NAWQC than lowest chronic values and may come to have the same standing as NAWQC, but currently they are only proposed by the EPA.

As discussed in the introduction, the chronic benchmarks are to be used as lower screening benchmarks. The acute NAWQC and SAVs are to be used as upper screening benchmarks. However, because of their conservatism, exceedence of the SAV cannot be taken to indicate that severe effects are likely to be occurring. If an SAV is exceeded, the assessor should examine the acute values used to generate the Tier II values (Appendix A) and judge whether in fact severe effects are likely.

All of these benchmarks are based on toxicity tests conducted in the laboratory. Therefore, they should be compared to water concentrations that are as equivalent as possible to concentrations in test water which is nearly all dissolved. That is, they should be compared to concentrations dissolved in ambient water (i.e., 0.1-0.45 $\mu \mathrm{m}$ filtered before being preserved) (HECD 1992, Prothro 1993). Total recoverable concentrations, rather than dissolved concentrations, are often reported because they are required for human health risk assessments. However, for metals, total recoverable concentrations typically include 30-95\% particle bound material (HECD 1992). Therefore, total recoverable concentrations should be used for aquatic ecological risk assessments only if dissolved concentrations are not available.

The NAWQC for hardness dependent metals are based on a hardness of $100 \mathrm{mg} / \mathrm{L}$, which is appropriate for ambient waters on the Oak Ridge Reservation. If these benchmarks are applied to a site with hard or soft water, the NAWQC for those metals should be recalculated as recommended by the EPA.

\section{REFERENCES}

Adams, W. J. and B. B. Heidolph. 1985. "Short-cut chronic toxicity estimates using Daphnia magna." pp. 87-102. IN R. D. Cardwell, R. Purdy, and R. C. Bahner (eds.), Aquatic Toxicity and Hazard Assessment, Seventh Symposium. ASTM, Philadelphia, PA. 
Adelman, I. R., L. L. Smith, and G. D. Siesennop. 1976. "Chronic toxicity of Guthion to the fathead minnow (Pimephales promelas Rafinesque)." Bull. Environ. Contam. Toxicol. 15:726-733.

Adema, D. M. M. 1978. "Daphnia magna as a test animal in acute and chronic toxicity tests." Hydrobiologia. 59:125-134.

Adema, D. M. M. and I. G. J. Vink. 1981. "A comparative study of the toxicity of. 1,1,2trichloroethane, dieldrin, pentachlorophenol and 3,4 dichloroaniline for marine and fresh water organisms." Chemosphere. 10:533-554.

Ahmed, N. et al. 1984. Aquatic toxicity tests to characterize the hazard of volatile organic chemicals in water: A toxicity data summary-Parts I and II. EPA-600/3-84-009. U.S. Environmental Protection Agency, Duluth, Minn.

Alexander, H. C., W. M. McCarthy, and E. A. Bartlett. 1978. "Toxicity of perchloroethylene, trichloroethylene, 1,1,1-trichloroethane, and methylene chloride to fathead minnows (Pimephales promelas). Bull. Environ. Contam. Toxicol. 20:344-352.

Allison, D. T. and R. O. Hermanutz. 1977. Toxicity of diazinon to brook trout and fathead minnows. EPA-600/3-77-060. U.S. Environmental Protection Agency, Duluth, Minn.

Amelung, M. 1981. Auswirkungen gelöster Eisenverbindungen auf die Ei- und Larvalentwicklung von Salmo gairdneri (Richardson). Arch. Fisch Wiss. 32:77-87.

Arthur, J. W. and E. N. Leonard. 1970. "Effects of copper on Gammarus pseudolimnaeus, Physa integra, and Campeloma decisum in soft water." J. Fish. Res. Bd. Canada. 27:1277-1283.

Arthur, J. W. and J. G. Eaton. 1970. "Effects of copper on Gammarus pseudolimnaeus and the fathead minnow (Pimephales promelas)." J. Fish. Res. Board Canada. 28:1841-1845.

Barnthouse, L. W., G. W. Suter II, and A. E. Rosen. 1990. "Risks of toxic contaminants to exploited fish populations: influence of life history, data uncertainty and exploitation intensity." Environ. Toxicol. Chem. 9:297-311.

Bartell, S. M. 1990. "Ecosystem context for estimating stress-induced reductions in fish populations," pp. 167-182, IN American Fisheries Society Special Symposium 8. Bethesda, MD.

Bartlett, L. and F. W. Rabe. 1974. "Effects of copper, zinc, and cadmium on Selenastrum capricornutum." Water Res. 8:179-185.

Benoit, D. A. 1975. "Chronic effects of copper on survival, growth, and reproduction of the bluegill (Lepomis macrochirus)." Trans. Am. Fish. Soc. 104:353-358.

Benoit, D. A., and G. W. Holcombe. 1978. "Toxic effects of zinc on fathead minnows Pimephales promelas in soft water." J. Fish Biol. 13:701-708. 
Benoit, D. A., F. A. Puglisi, and D. L. Olson. 1982. "A fathead minnow Pimephales promelas early life stage toxicity test method evaluation and exposure to four organic chemicals." Environ. Pollut. (Ser. A) 28:189-197.

Biesinger, K. E., L. E. Anderson, and J. G. Eaton. 1982. "Chronic effects of inorganic and organic mercury on Daphnia magna: toxicity, accumulation, and loss." Arch. Environm. Contam. Toxicol. 11:769-774.

Biesinger, K. E. and G. M. Christensen. 1972. "Effects of various metals on survival, growth, reproduction, and metabolism of Daphnia magna." J. Fish. Res. Bd. Canada. 29:1691-1700.

Black, J. A. and W. J. Birge. 1982. The aquatic toxicity of organic compounds to embryolarval stages of fish and amphibians. University of Kentucky, Water Resources Research Institute, Lexington, Kentucky.

Bluzat, R., O. Junot, G. Lespinasse, and J. Seuge. 1979. "Chronic toxicity of acetone in the fresh water snail Lymnea stagnalis." Toxicology. 14:179-190.

Borgmann, U., O. Kramar, and C. Loveridge. 1978. "Rates of mortality, growth, and biomass production of Lymnaia palustris during chronic exposure to lead." J. Fish. Res. Board Can. 35:1109-1115.

Brungs, W. A. 1969. Chronic toxicity of zinc to the fathead minnow Pimephales promelas Rafinesque." Trans. Am. Fish. Soc. 98:272-279.

Call, D. J., L. T. Brook, N. Ahmed, and J. E. Richter. 1983. Toxicity and metabolism studies with EPA priority pollutants and related chemicals in freshwater organisms. EPA-600/3-83-095. U.S. Environmental Protection Agency, Duluth, Minn.

Call, D. J., L. T. Brook, M.L. Knuth, S. H. Poirer, and M.D. Hoglund. 1985. "Fish subchronic toxicity prediction model for industrial organic chemicals that produce narcosis." Environ. Toxic. and Chem. 4:335-341.

Canton, J. H. and D. M. M. Adema. 1978. "Reproducibility of short-term and reproduction toxicity experiments with Daphnia magna and comparison of the sensitivity of Daphnia magna with Daphnia pulex and Daphnia cucullata in short-term experiments." Hydrobiologia. 59:135-140.

Cardwell, R. D., D. G. Foreman, T. R. Payne, and D. J. Wilbur. 1977. Acute and chronic toxicity of chlordane to fish and invertebrates, EPA-600/3-77-019. U.S. Environmental Protection Agency, Duluth, Minn.

Carlson, A. R. and P. A. Kosian. 1987. "Toxicity of chlorinated benzenes to fathead minnows (Pimephales promelas)." Arch. Environ. Contam. Toxicol. 16:129-135.

Carlson, A. R. et al. 1982. Cadmium and endrin toxicity to fish in waters containing mineral fibers, EPA-600/3-82-053. U.S. Environmental Protection Agency, Duluth, Minn. 
Chapman, G. A., S. Ota, and F. Recht. n.d. Effects of water hardness on the toxicity of metals to Daphnia magna. U.S. Environmental Protection Agency, Corvallis, Oregon.

Cleveland, L., E. E. Little, S. J. Hamilton, D. R. Buckler, and J. B. Hunn. 1986. "Interactive toxicity of aluminum and acidity to early life stages of brook trout." Trans. Amer. Fish. Soc. 115:610-620.

Conway, H. L. 1977. "Sorption of arsenic and cadmium and their effects on growth, micronutrient utilization, and photosynthetic pigment composition of Asterionella formosa." $J$. Fish. Res. Board Can. 35:26-294.

Cowell, B. C. 1965. "The effects of sodium arsenite and silex on the plankton populations in farm ponds." Trans. Am. Fish. Soc. 94:371-377.

Cushman, R. M., S. G. Hildebrand, R. H. Strand, and R. M. Anderson. 1977. The toxicity of 35 trace elements in coal to freshwater biota: a data base with automated retrieval capabilities. ORNL/TM-5793. Oak Ridge National Laboratory.

Dave, G. 1984a. "Effects of copper on growth, reproduction, survival and haemoglobin in Daphnia magna." Comp. Biochem. Physiol. 78C:439-443.

Dave, G. 1984b. "Effects of fluoride on growth, reproduction, and survival in Daphnia magna." Comp. Biochem. Physiol. 78C:425-431.

Dave, G. 1984c. "Effects of waterborne iron on growth, reproduction, survival and haemoglobin in Daphnia magna." Comp. Biochem. Physiol. 78C:433-438.

Davies, P. H., J. P. Goettl, Jr., and J. R. Sinley. 1978. "Toxicity of silver to rainbow trout (Salmo gairdneri)." Water Res. 12:113-117.

Davies, P. H., J. P. Goettl, Jr., J. R. Sinley, and Smith. 1976. "Acute and chronic toxicity of lead to rainbow trout Salmo gairdneri, in hard and soft water." Water Res. 10:199-206.

Dawson, G. W., A. L. Jennings, D. D. Drozdowski, and E. Rider. 1977. "The acute toxicity of 47 industrial chemicals to fresh and saltwater fishes." J. Haz. Mater. 1:303-318.

DeFoe, D. L., G. D. Veith, and R. L. Carlson. 1978. "Effects of Aroclor 1248 and 1260 on the fathead minnow (Pimephales promelas)." J. Fish. Res. Board Can. 7:997-1002.

DeGraeve, G. M., R. G. Elder, D. C. Woods, and H. L. Bergman. 1982. "Effects of naphthalene and benzene on fathead minnows and rainbow trout." Arch. Environ. Contam. Toxicol. 11:478-490.

DeGraeve, G. M., D. L. Geiger, J. S. Meyer, and H. L. Bergman. 1980. "Acute and embryo-larval toxicity of phenolic compounds to aquatic biota." Arch. Environ. Contam. Toxicol. 9:557-568. 
Dill, D. C., P. G. Murphy, and M. A. Mayes. 1987. "Toxicity of methylene chloride to life stages of the fathead minnow, Pimephales promelas Rafinesque." Bull. Environ. Contam. Toxicol. 39:869-876.

Dominguez, S. E. and G. A. Chapman. 1984. "Effect of pentachlorophenol on the growth and mortality of embryonic and juvenile steelhead trout." Arch. Environ. Contam. Toxicol. 13:739-743.

Dwyer, W. P., F. L. Mayer, J. L. Allen, and D. R. Buckler. 1978. "Chronic and simulated usepattern exposures of brook trout (Salvelinus fontinalis) to 3-trifluoromethyl-4-nitrophenol (TFM)." Investigations in Fish Control. 84:1-6.

Eaton, J. G. 1974. "Chronic cadmium toxicity to the bluegill (Lepomis macrochirus Rafinesque)." Trans. Am. Fish. Soc. 103:729-735.

Elnabarawy, M. T., A. N. Welter, and R. R. Robideau. 1986. "Relative sensitivity of three daphnid species to selected organic and inorganic chemicals." Environ. Toxicol. Chem. 5:393-398.

EPA. (n.d.). AQUIRE: Aquatic Information Retrieval Toxicity Data Base. National Technical Information Service, Springfield, Va.

EPA. 1978. In-depth studies on health and environmental impacts of selected water pollutants. Contract No. 68-01-4646. U.S. Environmental Protection Agency, Washington, D.C.

EPA. 1980a. Ambient water quality criteria for acenaphthene. EPA 440/5-80-015. U.S. Environmental Protection Agency, Washington, D.C.

EPA. 1980b. Ambient water quality criteria for antimony. EPA 440/5-80-020. U.S. Environmental Protection Agency, Washington, D.C.

EPA. 1980c. Ambient water quality criteria for benzidene. EPA 440/5-80-023. U.S. Environmental Protection Agency, Washington, D.C.

EPA. 1980d. Ambient water quality criteria for benzene. EPA 440/5-80-018.

U.S. Environmental Protection Agency, Washington, D.C.

EPA. 1980e. Ambient water quality criteria for benzidene. EPA 440/5-80-023.

U.S. Environmental Protection Agency, Washington, D.C.

EPA. 1980f. Ambient water quality criteria for beryllium. EPA 440/5-80-024. U.S. Environmental Protection Agency, Washington, D.C.

EPA. 1980g. Ambient water quality criteria for cadmium. EPA 440/5-80-025. U.S. Environmental Protection Agency, Washington, D.C.

EPA. 1980h. Ambient water quality criteria for carbon tetrachloride. EPA 440/5-80-026. 
U.S. Environmental Protection Agency, Washington, D.C.

EPA. 1980i. Ambient water quality criteria for chlordane. EPA 440/5-80-027. U.S. Environmental Protection Agency, Washington, D.C.

EPA. 1980j. Ambient water quality criteria for chlorinated benzenes. EPA 440/5-80-029. U.S. Environmental Protection Agency, Washington, D.C.

EPA. 1980k. Ambient water quality criteria for chlorinated ethanes. EPA 440/5-80-029. U.S. Environmental Protection Agency, Washington, D.C.

EPA. 19801. Ambient water quality criteria for chloroform. EPA 440/5-80-033. U.S. Environmental Protection Agency, Washington, D.C.

EPA. 1980m. Ambient water quality criteria for DDT. EPA 440/5-80-038. U.S. Environmental Protection Agency, Washington, D.C.

EPA. 1980n. Ambient water quality criteria for dichloroethylenes. EPA 440/5-80-041. U.S. Environmental Protection Agency, Washington, D.C.

EPA. 1980o. Ambient water quality criteria for dichloropropane and dichloropropene. EPA 440/5-80-043. U.S. Environmental Protection Agency, Washington, D.C.

EPA. 1980p. Ambient water quality criteria for ethylbenzene. EPA 440/5-80-048.

U.S. Environmental Protection Agency, Washington, D.C.

EPA. 1980q. Ambient water quality criteria for fluoranthene. EPA 440/5-80-049.

U.S. Environmental Protection Agency, Washington, D.C.

EPA. 1980r. Ambient water quality criteria for heptachlor. EPA 440/5-80-052.

U.S. Environmental Protection Agency, Washington, D.C.

EPA. 1980s. Ambient water quality criteria for hexachlorocyclohexane. EPA 440/5-80-054.

U.S. Environmental Protection Agency, Washington, D.C.

EPA. 1980t. Ambient water quality criteria for naphthalene. EPA 440/5-80-059. U.S. Environmental Protection Agency, Washington, D.C.

EPA. 1980u. Ambient water quality criteria for nitrophenols. EPA 440/5-80-063. U.S. Environmental Protection Agency, Washington, D.C.

EPA. 1980v. Ambient water quality criteria for phenol. EPA 440/5-80-066.

U.S. Environmental Protection Agency, Washington, D.C.

EPA. 1980w. Ambient water quality criteria for phthalate esters. EPA 440/5-80-067.

U.S. Environmental Protection Agency, Washington, D.C. 
EPA. 1980x. Ambient water quality criteria for polychlorinated biphenyls. EPA 440/5-80-068.

U.S. Environmental Protection Agency, Washington, D.C.

EPA. 1980y. Ambient water quality criteria for silver. EPA 440/5-80-071. U.S. Environmental Protection Agency, Washington, D.C.

EPA. 1980z. Ambient water quality criteria for beryllium. NTIS, Springfield, Virginia.

EPA. 1980aa. Ambient water quality criteria for tetrachloroethylene. EPA 440/5-80-073. U.S. Environmental Protection Agency, Washington, D.C.

EPA. 1980bb. Ambient water quality criteria for thallium. EPA 440/5-80-074. U.S. Environmental Protection Agency, Washington, D.C.

EPA. 1980cc. Ambient water quality criteria for toluene. EPA 440/5-80-075. U.S. Environmental Protection Agency, Washington, D.C.

EPA. 1980dd. Ambient water quality criteria for trichloroethylene. EPA 440/5-80-077. U.S. Environmental Protection Agency, Washington, D.C.

EPA. 1980ee. Ambient water quality criteria for nitrosamines. EPA 440/5-80-064. U.S. Environmental Protection Agency, Washington, D.C.

EPA. 1984a. Ambient water quality criteria for cadmium - 1984. EPA 440/5-84-032. U.S. Environmental Protection Agency, Washington, D. C.

EPA. 1985a. Ambient water quality criteria for ammonia - 1984. EPA 440/5-85-001. U.S. Environmental Protection Agency, Washington, D.C.

EPA. 1985b. Ambient water quality criteria for arsenic - 1984. EPA 440/5-84-033. U.S. Environmental Protection Agency, Washington, D.C.

EPA. 1985c. Ambient water quality criteria for chromium - 1984. EPA 440/5-84-029. U.S. Environmental Protection Agency, Washington, D.C.

EPA. 1985d. Ambient water quality criteria for copper - 1984. EPA 440/5-84-031. U.S. Environmental Protection Agency, Washington, D.C.

EPA. 1985e. Ambient water quality criteria for cyanide - 1984. EPA 440/5-84-030. U.S. Environmental Protection Agency, Washington, D.C.

EPA. 1985f. Ambient water quality criteria for lead - 1984. EPA 440/5-84-027. U.S. Environmental Protection Agency, Washington, D.C.

EPA. 1985g. Ambient water quality criteria for mercury - 1984. EPA 440/5-84-026. U.S. Environmental Protection Agency, Washington, D.C. 
EPA. 1986a. Ambient water quality criteria for nickel - 1986. EPA 440/5-86-004. U.S. Environmental Protection Agency, Washington, D.C.

EPA. 1986b. Quality criteria for water. EPA 440/5-86-001. U.S. Environmental Protection Agency, Washington, D.C.

EPA. 1987a. Ambient water quality criteria for selenium, 1987. EPA 440/5-87-006. U.S. Environmental Protection Agency, Washington, D.C.

EPA. 1987b. Ambient water quality criteria for zinc, 1987. EPA 440/5-87-003. U.S. Environmental Protection Agency, Washington, D.C.

EPA. 1988. Ambient water quality criteria for aluminum - 1988. EPA 440/5-86-008. U.S. Environmental Protection Agency, Washington, D.C.

EPA. 1993a. "Water quality guidance for the Great Lakes System and correction; Proposed rules." Federal Register. 58(72):20802-21047.

EPA. 1993b. Sediment quality criteria for the protection of benthic organisms - acenaphthene. EPA-822-R-93-013. U.S. Environmental Protection Agency, Washington, D.C.

EPA. 1993c. Sediment quality criteria for the protection of benthic organisms - fluoranthene. EPA-822-R-93-012. U.S. Environmental Protection Agency, Washington, D.C.

Ernst, W. R. and E. T. Garside. 1987. "Lethal effects of vanadium to two life stages of brook trout Salvelinus fontinalis (Mitchill)." Can. J. Zool. 65:628-634.

Ewald, W. G., J. E. French, and M. A. Champ. 1976. "Toxicity of Polychlorinated Biphenyls (PCBs) to Euglena gracilis: Cell Population Growth, Carbon Fixation, Chlorophyll Level, Oxygen Consumption, and Protein and Nucleic Acid Synthesis." Bull. Environ. Contam. Toxicol. 16:71-80.

Finlayson, B. J., and K. M. Verrue. 1985. "Toxicities of butoxyethanol ester and propylene glycol butyl ether ester formulations of 2,4-dichlorophenoxy acetic acid (2,4-D) to juvenile salmonids." Arch. Environ. Contam. Toxicol. 14:153-160.

Francis, P. C., D. W. Grothe, and J. C. Scheuring. 1986. "Chronic toxicity of 4-nitrophenol to Daphnia magna Straus under static-renewal and flow-through conditions." Bull. Environ. Contam. Toxicol. 36:730-737

Geiger, J. G. and A. L. Buikema Jr. 1982. "Hydrocarbons depress growth and reproduction of Daphnia pulex (Clodocera)." Can. J. Fish. Aquat. Sci. 39:830-836.

Gerisch, F. M. 1984. "Evaluation of static renewal chronic toxicity test method for Daphnia magna Straus using boric acid." Environ. Toxicol. Chem. 3:89-94.

Goettl, J. P., Jr. and P. H. Davies. 1976. "Water pollution studies." Federal Aid Project F-33- 
R-11. Department of Natural Resources, Colorado Division of Wildlife.

Hannah, J. B., J. E. Hose, M. L. Landolt, B. S. Miller, S. P. Felton, and W. T. Iwaoko. 1982. "Benzo(a)pyrene-induced morphologic and developmental abnormalities in rainbow trout." Arch. Environ. Contam. Toxicol. 11:727-734.

Hamelink, J. L., D. R. Buckler, f. L. Mayer, D. U. Palawski, and H. O. Sanders. 1986. "Toxicity of fluoridone to aquatic invertebrates and fish." Environ. Toxicol. Chem. 5:97-94.

Hazel, C. R. and S. J. Meith. 1970. "Bioassay of king salmon eggs and sac fry in copper solutions." Calif. Fish Game. 2:121-124.

HECD (Health and Criteria Division). 1992. Interim guidance on interpretation and implementation of aquatic life criteria for metals. U.S. Environmental Protection Agency, Washington, D.C.

Hermanutz, R. O., R. H. Mueller, and K. D. Kempfer. 1973. "Captan toxicity to fathead minnows (Pimephales promelas), bluegills (Lepomis macrochirus), and brook trout (Salvelinus fontinalis)." J. Fish. Res. Board Can. 30:1811-1817.

Holcombe, G. W., D. A. Benoit, E. N. Leonard, and J. M. McKim. 1976. "Long term effects of lead exposure on three generations of brook trout (Salvelinus fontinalis)." J. Fish. Res. Board Can. 33:1731-1741.

Holcombe, G. W., G. L. Phipps, and J. T. Fiandt. 1982. "Effects of phenol, 2,4dimethylphenol,2,4-dichlorophenol, and pentachlorophenol on embryo, larval, and earlyjuvenile fathead minnows (Pimephales promelas)." Arch. Environ. Contam. Toxicol. 11(1):73-78.

Holcombe, G. W., G. L. Phipps, and J. T. Fiandt. 1983. "Toxicity of selected priority pollutants to various aquatic organisms." Ecotoxicol. Environ. Saf. 7400-409.

Holdway, D. A. and J. B. Sprague. 1979. "Chronic toxicity of vanadium to flagfish." Water Res. 13:905-910.

Holman, W. F., and K. J. Macek. 1980. "An aquatic safety assessment of linear alkylbenzsulfonate (LAS): chronic effects on fathead minnows." Trans. Am. Fish. Soc. 109:122-131.

Holst, L. L. and J. P. Giesy. 1989. "Chronic effects of the photoenhanced toxicity of anthracene on Daphnia magna reproduction." Environ. Toxicol. Chem. 8:933-942.

Ingersoll, C. G. et al. 1990a. "Aluminum and acid toxicity to two strains of brook trout (Salvelinus fontinalis)." Can. J. Fish. Aquat. Sci. 47:1641-1648.

Ingersoll, C. G. et al. 1990b. "Effects of pH, aluminum, and calcium on survival and growth of eggs and fry of brook trout (Salvelinus fontinalis)." Can. J. Fish. Aquat. Sci. 47:1580-1592. 
Jarvinen, A. W., M. J. Hoffman, and T. W. Thorslund. 1977. "Long-term toxic effects of DDT food and water exposure on fathead minnows (Pimephales promelas)." J. Fish. Res. Board Can. 34:2089-2103.

Jarvinen, A. W., B. R. Nordling, and M. E. Henry. 1983. "Chronic toxicity of dursban (chlorpyrifos) to the fathead minnow (Pimephales promelas) and the resultant acetylcholinesterase inhibition." Ecotoxicol. Environ. Safety. 7:423-434.

Johnston, P. A. 1987. "Acute toxicity of inorganic selenium to Daphnia magna (Straus) and the effect of sub-acute exposure upon growth and reproduction." Aquat. Toxicol. 10:335-352.

Karlander, E. P. and R. W. Krauss. 1972. "Absorption and toxicity of beryllium and lithium in Chlorella vannielii Shihira and Krauss." Chesapeake Science. 13:245-253.

Kauss, P. B. and T. C. Hutchinson. 1975. "The effects of water-soluble petroleum components on the growth of Chlorella vulgaris Beijerinck." Environ. Pollut. 9:157-174.

Kimball, G. n.d. "The effects of lesser known metals and one organic to fathead minnows [Pimephales promelas] and Daphnia magna. U.S. Environmental Protection Agency, Duluth, MN.

Kleiner, C. F., R. L. Anderson, and D. K. Tanner. 1984. "Toxicity of fenitrothion to fathead minnows (Pimephales promelas) and alternate exposure duration studies with fenitrothion and endosulfan." Arch. Environ. Contam. Toxicol. 13:573-578.

Koenst, W. M., L. L. Smith, Jr., and S. J. Broderius. 1977. "Effect of chronic exposure of brook trout to sublethal concentrations of hydrogen cyanide." Environmental Science and Technology 11:883-886.

Krishnakumari, M. K. 1977. "Sensitivity of the alga Scenedesmus acutus to some pesticides." Life Sciences. 20:1525-1532.

Kszos, L. A., A. J. Stewart, and P. A. Taylor. 1992. "An evaluation of nickel toxicity to Ceriodaphnia dubia and Daphnia magna in a contaminated stream and in laboratory tests." Environ. Toxicol. Chem. 11:1001-1012.

Larsson, L. and J. Tillberg. 1975. "Effects of the Commercial Polychlorinated Biphenyl Mixture Aroclor 1242 on Growth, Viability, Phosphate Uptake, Respiration and Oxygen Evolution in Scenedesmus." Physiol. Plant 33:256-260.

Lazareva, L. P. 1985. "Changes in biological characteristics of Daphnia magna from chronic action of copper and nickel at low concentrations." Hydrobiol. J. 21(5):59-62.

LeBlanc, G. A. 1980. "Acute toxicity of priority pollutants to water flea (Daphnia magna)." Bull. Environ. Contam. Toxicol. 24:684-691.

LeBlanc, G. A., J. D. Mastone, A. P. Paradice, B. F. Wilson, H. B. Lockhart, Jr., and K. A. 
Robillard. 1984. "The influence of speciation on the toxicity of silver to fathead minnow (Pimephales promelas)." Environ. Toxicol. Chem. 3:37-46.

Leduc, G. 1978. "Deleterious effects of cyanide on early life stages of atlantic salmon (Salmo salar)." J. Fish. Res. Board Can. 35:166-174.

Lewis, M. A. and L. C. Valentine. 1981. "Acute and chronic toxicities of boric acid to Daphnia magna Straus." Bull. Environ. Contam. Toxicol. 27:309-315.

Lima, A. R. et al. 1984. "Acute and chronic toxicities of arsenic (III) to fathead minnows, flagfish, daphnids, and an amphipod." Arch. Environ. Contam. Toxicol. 13:595-601.

Lind, D., K. Alto, and S. Chatterton. 1978. Regional copper-nickel study; aquatic toxicology study. Minnesota Environmental Quality Board.

Luard, E. J. 1973. "Sensitivity of Dunaliella and Scenedesmus (Chlorphyceae) to Chlorinated hydrocarbons." Phycologia 12:29-33.

Macek, K. J., K. S. Buxton, S. K. Derr, J. W. Dean, and S. Sauter. 1976a. Chronic toxicity of lindane to selected aquatic invertebrates and fish. EPA-600/3-76-046. U.S. Environmental Protection Agency, Duluth, Minn.

Macek, K. J., M. A. Lindberg, S. Sauter, K. Buxton, and P. A. Costa. 1976b. Toxicity of four pesticides to water fleas and fathead minnows. -EPA-600/3-76-099. U.S. Environmental Protection Agency, Duluth, Minn.

Mauck, W. L., P. M. Mehrle, and F. L. Mayer. 1978. Effects of the polychlorinated biphenyl Aroclor 1254 on growth, survival, and bone development in brook trout (Salvelinus fontinalis)." J. Fish. Res. Board Can. 35:1084-1088.

Mayer, F. L., Jr., P. M. Mehrle, Jr., and W. P. Dwyer. 1975. Toxaphene effects on reproduction, growth and mortality of brook trout. EPA-600/3-75-013. U. S. Environmental Protection Agency, Duluth, Minn.

Mayer, F. L., Jr., P. M. Mehrle, H. O. Sanders. 1977. "Residue dynamics and biological effects of polychlorinated biphenyls in aquatic organisms." Arch. Environ. Contam. Toxicol. 5:501-511.

Mayer, F. L., Jr., and H. O. Sanders. 1973. "Toxicology of phthalic acid esters in aquatic organisms." Environmental Health Perspectives 5:153-157.

Mayer, F. L., Jr. and M. R. Ellersieck. 1986. Manual of acute toxicity: interpretation and data base for 410 chemicals and 66 species of freshwater organisms. Resource Publication 160. U.S. Fish and Wildlife Service, Washington, D.C.

Mayes, M. A., H. C. Alexander, D. L. Hopkins, P. B. Latvaitis. 1986. "Acute and chronic toxicity of ammonia to freshwater fish: a site-specific study." Environ. Toxicol. Chem. 
$5: 437-442$.

McCarthy, J. F. and D. K. Whitmore. 1985. "Chronic toxicity of di-n-butyl and di-n-octyl phthalate to Daphnia magna and the fathead minnow." Environ. Toxicol. Chem. 4:167-179.

McCauley, D. J., L. T. Brooke, D. J. Call, and C. A. Lindberg. 1986. Acute and chronic toxicity of aluminum to Ceriodaphnia dubia at various pH's. Center for Lake Superior Environmental Studies, University of Wisconsin-Superior, Superior, Wis.

McKim, J. M., and D. A. Benoit. 1971. "Effects of long-term exposures to copper on survival, growth, and reproduction of brook trout (Salvelinus fontinalis)." J. Fish. Res. Board Can. 28:655-662.

McKim, J. M., G. F. Olson, G. W. Holcombe, and E. P. Hunt. 1976. "Long-term effects of methylmercuric chloride on three generations of brook trout (Salvelinus fontinalis): toxicity, accumulation, distribution, and elimination." J. Fish. Res. Board Can. 33:2726-2739.

Mehrle, P. M., and F. L. Mayer. 1976. "Di-2-ethylhexyl phthalate: residue dynamics and biological effects in rainbow trout and fathead minnows." Trace Subst. Env. Health 10:519-524.

Mount, D. I. 1968. "Chronic toxicity of copper to fathead minnows (Pimephales promelas Rafinesque)." Water Res. 2:215-223.

Mount, D. I. 1982. Memorandum to Charles E. Spehar. U.S. Environmental Protection Agency, Duluth, Minn. June 7.

Mount, D. I., and C. E. Stephan. 1969. "Chronic toxicity of copper to the fathead minnow (Pimephales promelas) in soft water." J. Fish. Res. Board Can. 26:2449-2457.

Münzinger, A. 1990. "Effects of nickel on Daphnia magna during chronic exposure and alterations in the toxicity to generations pre-exposed to nickel." Wat. Res. 24:845-852.

Nebeker, A.' V., C. K. McAuliffe, R. Mshar, and D. G. Stevens. 1983. "Toxicity of silver to steelhead and rainbow trout, fathead minnows, and Daphnia magna." Environ. Toxicol. Chem. 2:95-104.

Nebeker, A. V., C. Savonen, R. J. Baker, J. K. McCrady. 1984. "Effects of copper, nickel, and zinc on the life cycle of the caddisfly Clistoronia magnifica (Limnephilidae)." Environ. Toxicol. Chem. 3:645-649.

Nebeker, A. V., C. Savonen, and D. G. Stevens. 1985. "Sensitivity of rainbow trout early life stages to nickel chloride." Environ. Toxicol. Chem. 4:233-239.

Nebeker, A. V., and F. A. Puglisi. 1974. "Effect of polychlorinated biphenyl (PCBs) on survival and reproduction of Daphnia, Gammarus, and Tanytarsus." Trans. Amer. Fish. Soc. 103:722-728. 
Nebeker, A. V., F. A. Puglisi, and D. L. DeFoe. 1974. "Effect of polychlorinated biphenyl compounds on survival and reproduction of the fathead minnow and flagfish." Trans. Amer. Fish. Soc. 103:562-568.

Oris, J. T., J. P. Giesy Jr. 1985. "The photoenhanced toxicity of anthracene to juvenile sunfish (Lepomis sp.)." Aquat. Toxicol. 6:133-146.

Oseid, D. M., L. L. Smith Jr. 1979. "The effects of hydrogen cyanide on Asellus communis and Gammarus pseudolimnaeus and changes in their competitive response when exposed simultaneously." Bull. Environ. Contam. Toxicol. 21:439-447.

Passino, D. R. and S. B. Smith. 1987. "Acute bioassays and hazard evaluation of representative contaminants detected in Great Lakes fish." Environ. Toxicol. Chem. 6:901-907.

Pickering, Q. H. 1974. "Chronic toxicity of nickel to the fathead minnow and flagfish." Trans. Am. Fish. Soc. 103:562-568.

Pickering, Q. H. 1980. "Chronic toxicity of hexavalent chromium to the fathead minnow (Pimephales promelas)." Arch. Environ. Contam. Toxicol. 9:405-413.

Pickering, Q. H. and M. H. Gast. 1972. "Acute and chronic toxicity of cadmium to the fathead minnow (Pimephales promelas)." J. Fish. Res. Board Can. 29:1099-1106.

Pickering, Q. H. and W. T. Gilliam. 1982. "Toxicity of aldicarb and fonofos to the early lifestage of the fathead minnow." Arch. Environ. Contam. Toxicol. 11:699-702.

Pickering, Q. H., and T. O. Thatcher. 1970. "The chronic toxicity of linear allcylate sulfonate (LAS) to Pimephales promelas, Rafinesque." J. Water Pollut. Control Fed. 42:243-254.

Prothro, M. G. 1993. Office of Water Policy and Technical Guidance on Interpretation and Implementation of Aquatic Life Metals Criteria. Memorandum to Water Management Division Directors and Environmental Services Division Directors, Regions I-X, October 1, 1993.

Rai, L. C., J. P. Gaur, H. D. Kumar. 1981. "Protective effects of certain environmental factors on the toxicity of zinc, mercury, and methylmercury to Chlorella vulgaris." Environ. Res. 25:250-259.

Randall, T. L. and P. V. Knopp. 1980. "Detoxification of specific organic substances by wet oxidation." J. Water Pollut. Control Fed. 52(8):2117-2130.

Reynolds, J. H., E. J. Middlebrooks, D. B. Porcella, W. J. Grenney. 1975. "Effects of temperature on oil refinery waste toxicity." J. Water Poll. Control Fed. 47:2674-2693.

Richter, J.E., S. F. Peterson, and C. F. Kleiner. 1983. "Acute and chronic toxicity of some chlorinated benzenes, chlorinated ethanes, and tetrachloroethylene to Daphnia magna." Arch. Environ. Contam. Toxicol. 12:679-684. 
Sadler, K. and S. Lynam. 1988. "The influence of calcium on aluminum-induced changes in the growth rate and mortality of brown trout, Salmo trutta L." J. Fish Biol. 33:171-179.

Sauter, S., K. S. Buxton, K. J. Macek, and S. R. Petrocelli. 1976. Effects exposure to heavy metals on selected freshwater fish. EPA-600/3-76-105. U.S. Environmental Protection Agency, Duluth, Minn.

Seim, W. K., L. R. Curtis, S. W. Blenn, and G. A. Chapman. 1984. "Growth and survival of developing steelhead trout (Salmo gairdneri) continuously or intermittently exposed to copper." Can. J. Fish. Aquat. Sci. 41:433-438.

Sinley, J. R., J. P. Goettl, Jr., and P. H. Davies. 1974. "The effects of zinc on rainbow trout (Salmo gairdneri) in hard and soft water." Bull. Environ. Contam. Toxicol. 12:193-201.

Smith, A. D. et al. 1991. "The acute and chronic toxicity of ten chlorinated organic compounds to the American Flagfish (Jordanella floridae)." Arch. Environ. Contam. Toxicol. 20:94-102.

Smith, L. L., S. J. Broderius, D. M. Oseid, G. L. Kimball, W. M. Koenst, and D. T. Lind. 1979. Acute and chronic toxicity of HCN to fish and invertebrates. EPA-600/3-79-009. U.S. Environmental Protection Agency.

Smith, L. R., T. M. Holsen, N. C. Ibay, R. M. Block, and A. B. de Leon. 1985. "Studies on the acute toxicity of fluoride ion to stickleback, fathead minnow, and rainbow trout." Chemosphere 14(9):1383-1389.

Snarski, V. M., and G. F. Olson, 1982. "Chronic toxicity and bioaccumulation of mercuric chloride in the fathead minnow (Pimephales promelas). Aquat. Toxicol. 2:143-156.

Spehar, R. L. 1976. "Cadmium and zinc toxicity to flagfish, Jordanella floridae." J. Fish. Res. Board Can. 33:1939-1945.

Spehar, R. L., J. T. Fiandt, R. L. Anderson, and D. L. DeFoe. 1980. "Comparative toxicity of arsenic compounds and their accumulation in invertebrates and fish." Arch. Environ. Contam. Toxicol. 9:53-63.

Spehar, R. L., D. K. Tanner, and B. R. Nordling. 1983. "Toxicity of the synthetic pyrethroids, permethrin, and AC 222,705 and their accumulation in early life stages of fathead minnows and snails." Aquat. Toxicol. 3:171-182.

Stalling, D. L. and F. L. Mayer Jr. 1972. "Toxicities of PCBs to fish and environmental residues." Environ. Health Perspectives. 1:159-164.

Steeman-Nielsen, E. and S. Wium-Andersen. 1970. "Copper ions as poison in the sea and freshwater." Marine Biology. 6:93-97.

Stephan, C. E. 1991. Letter to Mr. Jim Grant. Michigan Department of Natural Resources. 
Stephan, C. E., D. I. Mount, D. J. Hansen, J. H. Gentile, G. A.Chapman, and W. A. Brungs. 1985. Guidelines for deriving numerical national water quality criteria for the protection of aquatic organisms and their uses. PB85-227049. National Technical Information Service, Springfield, Va.

Stephan, C. E., and J. R. Rogers. 1985. "Advantages of using regression analysis to calculate results of chronic toxicity tests," pp. 328-339 in Aquatic Toxicology and Hazard Assessment: Eighth Symposium, R. C. Bahner and D. J. Hansen (eds.), American Society for Testing and Materials, Philadelphia.

Stephan, E. E. and R. J. Erickson. n.d. Guidelines for deriving an aquatic life pesticide concentration. U.S. Environmental Protection Agency, Environmental Research Laboratory, Duluth, MN, unpublished document.

Stevens, D. G. and G. A. Chapman. 1984. "Toxicity of trivalent chromium to early life stages of steelhead trout." Environ. Toxicol. Chem. 3:125-133.

Suter, G. W. II. 1989. "Ecological endpoints," pp. 2-1-2-28, in Ecological Assessment of Hazardous Waste Sites: A Field and Laboratory Reference Document. EPA 600/3-89/013. W. Warren-Hicks, B. R. Parkhurst, and S. S. Baker, Jr. (eds.). Corvallis Environmental Research Laboratory, Oregon.

Suter, G. W., II, M. A. Futrell, G. A. Kerchner. 1992. Toxicological benchmarks for screening of potential contaminants of concern for effects on aquatic biota on the Oak Ridge Reservation, Oak Ridge, Tennessee. ORNL/ER-139. Oak Ridge National Laboratory.

Suter, G. W., II, A. E. Rosen, E. Linder, and D. F. Parkhurst. 1987. "End points for responses of fish to chronic toxic exposures." Environ. Toxicol. Chem. 6:793-809.

Suter, G. W., II. 1992. Ecological Risk Assessment. Lewis Publishers, Chelsea, MI.

Suter, G. W., II, A. Redfearn, R. K. White, and R. A. Shaw. 1992. Approach and strategy for performing ecological risk assessments for the Department of Energy Oak Ridge Field Office Environmental Restoration Program. ES/ER/TM-33. Environmental Restoration Division, Oak Ridge National Laboratory, Oak Ridge, TN.

Thompson, R. S., and N. G. Carmichael. 1989. "1,1,1-Trichloroethane: medium-term toxicity to carp, daphnids, and higher plants." Ecotox. Environ. Safety 17:172-182.

Thurston, R.V., R.C. Russo, E.L. Meyn, and R.K. Zajdel. 1986. "Chronic toxicity of ammonia to fathead minnows." Trans. Amer. Fish. Soc. 115:196-207.

Trucco, R. G., F. R. Engelhardt, B. Stacey. 1983. "Toxicity, accumulation, and clearance of aromatic hydrocarbons in Daphnia pulex." Environ. Pollut. 31:191-202.

Van der Schalie, W. H. 1983. The acute and chronic toxicity of 3,5-dinitroaniline, 1,3dinitrobenzene, and 1,3,5-trinitrobenzene to freshwater aquatic organisms. Technical Report 
8305. U.S. Army Medical Bioengineering Research and Development Laboratory, Fort Detrick, Frederick, MD.

Van Leeuwen, C. J. and H. Maas. 1985. "The aquatic toxicity of 2,6-dichlorobenzamide (BAM), a degradation product of the herbicide dichlobenil." Environ. Pollut. Ser. A. 37:105-115.

Van Leeuwen, C. J., J. L. Maas-Diepeveen, G. Niebeek, W. H. A. Vergouw, P. S. Griffioen, M. W. Luijken. 1985. "Aquatic toxicological aspects of dithiocarbamates and related compounds. I. short-term toxicity tests." Aquat. Toxicol. 7:145-164.

Vareille-Morel, C. and J. Debord. 1990. "Sensibilité du Mollusque prosobranche Potamopyrgus jenkinsi Smith à l'action de chlorures métalliques $\left(\mathrm{ZnCl}_{2}, \mathrm{BaCl}_{2}, \mathrm{CuCl}_{2}\right)$ et d'un molluscicide de synthèse, la N-tributyl-morpholine." Ann Rech. Vét. 21:111-118.

Veith, G. D., D. J. Call, L. T. Brooke. 1983. "Estimating the acute toxicity of narcotic industrial chemicals to fathead minnows," pp. 90-97, in Aquatic Toxicol. and Hazard Assessment: Sixth Symposium. W. E. bishop, R. D. Cardwell, and B. B. Heidolph (eds.), ASTM STP 802, Philadelphia.

Vocke, R. W., K. L. Sears, J. J. O’Toole, R. B. Wildham. 1980. "Growth responses of selected freshwater algae to trace elements and scrubber ash slurry generated by coal-fired power plants." Water Res. 14:141-150.

Walbridge, C. T., J. T. Fiandt, G. L. Phipps, and G. W. Holcombe. 1983. "Acute toxicity of ten chlorinated aliphatic hydrocarbons to the fathead minnow (Pimephales promelas)." Arch. Environ. Toxicol. 12:661-666.

Ward, T. J., and R. L. Boeri. 1991a. Early Life Stage Toxicity of Di-n-Butyl Phthalate (DnBP) to the rainbow Trout (Oncorhynchus mykiss) Under Flow-Through Conditions. 9102-CMA. Chemical Manufacturers Association, Washington, D.C.

Woodward, D. F., A. M. Farag, M. E. Mueller, E. E. Little, F. A. Vertucci. 1989. "Sensitivity of endemic Snake River cutthroat trout to acidity and elevated aluminum. "Trans. Amer. Fish. Soc. 118:630-643. 
APPENDIX A

DATA USED FOR TIER II CALCULATIONS 
THIS PAGE INTENTIONALLY LEFT BLANK 
A-3

Table A.1. Data Used for Tier II Calculations (all values in $\mu \mathrm{g} / \mathrm{l}$ )

\begin{tabular}{|c|c|c|c|}
\hline Chemical Name/Data type & Value & Species & Source \\
\hline \multicolumn{4}{|c|}{ INORGANICS } \\
\hline Antimony & & & \\
\hline Acute values: & $\begin{array}{r}9000 \\
18,800 \\
21,900\end{array}$ & $\begin{array}{l}\text { Daphnia magna } \\
\text { Daphnia magna } \\
\text { Fathead minnow }\end{array}$ & $\begin{array}{l}\text { EPA 1980b } \\
\text { Kimball n.d. } \\
\text { ibid. }\end{array}$ \\
\hline SAV: & 985 & & \\
\hline A-C ratios: & $\begin{array}{l}3.481 \\
13.69\end{array}$ & $\begin{array}{l}\text { Daphnia magna } \\
\text { Fathead minnow }\end{array}$ & $\begin{array}{l}\text { Kimball n.d. } \\
\text { ibid. }\end{array}$ \\
\hline SACR: & 9.5 & & \\
\hline SCV': & 104 & & \\
\hline \multicolumn{4}{|l|}{ Arsenic V } \\
\hline Acute values: & $\begin{array}{r}<8100 \\
7400 \\
\\
3600 \\
49,600 \\
850 \\
\\
10,800 \\
25,600 \\
49,000\end{array}$ & $\begin{array}{l}\text { Daphnia magna } \\
\text { Daphnia magna } \\
\\
\text { Daphnia pulex } \\
\text { Daphnia pulex } \\
\text { Bosmina } \\
\text { longirostris } \\
\text { Rainbow trout } \\
\text { Fathead minnow } \\
\text { Mosquitofish }\end{array}$ & $\begin{array}{l}\text { EPA 1985b } \\
\text { Biesinger and } \\
\quad \text { Christensen } 1972 \\
\text { EPA 1985b } \\
\text { ibid. } \\
\text { ibid. } \\
\text { ibid. } \\
\text { DeFoe 1982 } \\
\text { EPA 1985b }\end{array}$ \\
\hline SAV: & 170 & & \\
\hline A-C ratios: & 28.7 & Fathead minnow & DeFoe 1982 \\
\hline SACR: & 20.9 & & \\
\hline scV: & 8.11 & & \\
\hline \multicolumn{4}{|l|}{ Barium } \\
\hline Acute values & $\begin{array}{r}410,000 \\
1700 \\
930 \\
330 \\
1330\end{array}$ & $\begin{array}{l}\text { Daphnia magna } \\
\text { Gastropod snail } \\
\text { Gastropod snail } \\
\text { Gastropod snail } \\
\text { Gastropod snail }\end{array}$ & $\begin{array}{l}\text { LeBlanc } 1980 \\
\text { Vareille-Morel } 1990 \\
\text { ibid. } \\
\text { ibid. } \\
\text { ibid. }\end{array}$ \\
\hline SAV: & 69.1 & & \\
\hline SACR: & 17.9 & & \\
\hline SCV & 3.8 & & \\
\hline
\end{tabular}




\section{A-4}

Table A.1. (continued)

\begin{tabular}{|c|c|c|c|}
\hline Chemical Name/Data type & Value & Species & Source \\
\hline \multicolumn{4}{|l|}{ Beryllium } \\
\hline \multirow[t]{29}{*}{ Acute values: } & 7900 & Daphnia magna & EPA $1980 f$ \\
\hline & 2500 & Daphnia magna & Kimball n.d. \\
\hline & 4800 & Goldfish & EPA $1980 f$ \\
\hline & 3250 & Fathead minnow & ibid. \\
\hline & 200 & Fathead minnow & ibid. \\
\hline & 150 & Fathead minnow & ibid. \\
\hline & 150 & Fathead minnow & ibid. \\
\hline & 11,000 & Fathead minnow & ibid. \\
\hline & 20,000 & Fathead minnow & ibid. \\
\hline & 15,000 & Fathead minnow & ibid. \\
\hline & 18,000 & Fathead minnow & Kimball n.d. \\
\hline & 4400 & Flagfish & EPA $1980 f$ \\
\hline & 3530 & Flagfish & ibid. \\
\hline & 3530 & Flagfish & ibid. \\
\hline & 32,000 & Guppy & ibid. \\
\hline & 28,000 & Guppy & ibid. \\
\hline & 32,000 & Guppy & ibid. \\
\hline & 24,000 & Guppy & ibid. \\
\hline & 160 & Guppy & ibid. \\
\hline & 19,000 & Guppy & ibid. \\
\hline & 450 & Guppy & ibid. \\
\hline & 130 & Guppy & ibid. \\
\hline & 200 & Guppy & ibid. \\
\hline & 20,000 & Guppy & ibid. \\
\hline & 13,700 & Guppy & ibid. \\
\hline & 6100 & Guppy & ibid. \\
\hline & 160 & Guppy & ibid. \\
\hline & 12,000 & Bluegill & ibid. \\
\hline & 1300 & Bluegill & $i b i d$. \\
\hline SAV: & 271 & & \\
\hline A-C ratios: & 472 & Daphnia magna & Kimball n.d. \\
\hline SACR: & 53.3 & & \\
\hline SCV: & 5.09 & & \\
\hline
\end{tabular}




\section{A-5}

Table A.1. (continued)

\begin{tabular}{|c|c|c|c|}
\hline Chemical Name/Data type & Value & Species & Source \\
\hline \multicolumn{4}{|l|}{ Boron } \\
\hline Acute values: & 226,000 & Daphnia magna & $\begin{array}{l}\text { Lewis and Valentine } \\
1981\end{array}$ \\
\hline SAV: & 11,024 & & \\
\hline Acute-Chronic ratios & 25.6 & Daphnia magna & $\begin{array}{l}\text { Lewis and Valentine } \\
1981\end{array}$ \\
\hline SACR: & 20.2 & & \\
\hline SCV: & 547 & & \\
\hline \multicolumn{4}{|l|}{ Cobalt } \\
\hline Acute values: & $\begin{array}{l}1110 \\
5990 \\
3610\end{array}$ & $\begin{array}{l}\text { Daphnia magna } \\
\text { Daphnia magna } \\
\text { Fathead minnow }\end{array}$ & $\begin{array}{l}\text { Biesinger and } \\
\text { Christensen } 1972 \\
\text { Kimball n.d. } \\
\text { ibid. }\end{array}$ \\
\hline SAV & 195 & & \\
\hline A-C ratios: & $\begin{array}{l}1175 \\
12.4\end{array}$ & $\begin{array}{l}\text { Daphnia magna } \\
\text { Fathead minnow }\end{array}$ & $\begin{array}{l}\text { Kimball n.d. } \\
\text { Kimball n.d. }\end{array}$ \\
\hline SACR: & 63.6 & & \\
\hline ScV: & 3.06 & & \\
\hline \multicolumn{4}{|l|}{ Fluoride } \\
\hline Acute values: & $\begin{array}{r}98,000 \\
251,000 \\
390,247 \\
200,000 \\
245,987 \\
125,000\end{array}$ & $\begin{array}{l}\text { Daphnia magna } \\
\text { Daphnia magna } \\
\text { Stickleback } \\
\text { Rainbow trout } \\
\text { Fathead minnow } \\
\text { Brown trout }\end{array}$ & $\begin{array}{l}\text { Dave 1984b } \\
\text { Fieser et al. } 1986 \\
\text { Smith et al. } 1985 \\
\text { ibid. } \\
\text { ibid. } \\
\text { (AQUIRE) }^{\text {e }}\end{array}$ \\
\hline SAV: & 19,230 & & \\
\hline A-C ratios: & $\begin{array}{r}8.33 \\
22.27\end{array}$ & $\begin{array}{l}\text { Daphnia magna } \\
\text { Daphnia magna }\end{array}$ & $\begin{array}{l}\text { Fieser et al. } 1986 \\
\text { Dave 1984b }\end{array}$ \\
\hline SACR: & 16.3 & & \\
\hline SCV: & 1177 & & \\
\hline
\end{tabular}




\section{A-6}

Table A.1. (continued)

\begin{tabular}{|c|c|c|c|}
\hline Chemical Name/Data type & Value & Species & Source \\
\hline \multicolumn{4}{|l|}{ Manganese } \\
\hline Acute values: & $\begin{array}{l}19,400 \\
33,800\end{array}$ & $\begin{array}{l}\text { Daphnia magna } \\
\text { Fathead minnow }\end{array}$ & $\begin{array}{l}\text { Kimball n.d. } \\
\text { ibid. }\end{array}$ \\
\hline SAV: & 1470 & & \\
\hline Acute-Chronic ratios & 19.10 & Fathead minnow & Kimball n.d. \\
\hline SACR: & 18.3 & & \\
\hline SCV: & 80.3 & & \\
\hline \multicolumn{4}{|l|}{ Mercury, inorganic } \\
\hline Final Acute Value: & 4.86 & & EPA $1985 \mathrm{~g}$ \\
\hline Final ACR: & 3.73 & & ibid. \\
\hline Final CV: & 1.30 & & ibid. \\
\hline \multicolumn{4}{|l|}{ Mercury, methyl } \\
\hline Acute values: & $\begin{array}{l}25 \\
24 \\
42 \\
24 \\
84 \\
65\end{array}$ & $\begin{array}{l}\text { Rainbow trout } \\
\text { Rainbow trout } \\
\text { Rainbow trout } \\
\text { Rainbow trout } \\
\text { Brook trout } \\
\text { Brook trout }\end{array}$ & $\begin{array}{l}\text { EPA } 1985 \mathrm{~g} \\
\text { ibid. } \\
\text { ibid. } \\
\text { ibid. } \\
\text { McKim et al. } 1976 \\
\text { ibid. }\end{array}$ \\
\hline SAV: & 0.12 & & \\
\hline A-C ratios: & 142.3 & Brook trout & ibid. \\
\hline SACR: & 35.7 & & \\
\hline SCV: & 0.0034 & & \\
\hline \multicolumn{4}{|l|}{ Molybdenum } \\
\hline Acute values: & 206,800 & Daphnia magna & Kimball n.d. \\
\hline SAV: & 10,087 & & \\
\hline A-C ratios: & 235 & Daphnia magna & Kimball n.d. \\
\hline SACR & 42.2 & & \\
\hline SCV: & 239 & & \\
\hline
\end{tabular}


A-7

Table A.1. (continued)

\begin{tabular}{|c|c|c|c|}
\hline Chemical Name/Data type & Value & Species & Source \\
\hline \multicolumn{4}{|l|}{ Silver } \\
\hline Final Acute Value: & 4.1 & & EPA 1980y \\
\hline A-C ratios: & $\begin{array}{r}2.0 \\
54 \\
14\end{array}$ & $\begin{array}{l}\text { Daphnia magna } \\
\text { Rainbow trout } \\
\text { Mysid shrimp }\end{array}$ & $\begin{array}{l}\text { EPA 1980y } \\
\text { ibid. } \\
\text { ibid. }\end{array}$ \\
\hline SACR: & 11.5 & & \\
\hline FAV/SACR: & 0.36 & & \\
\hline \multicolumn{4}{|l|}{ Strontium } \\
\hline Acute values: & 125,000 & Daphnia magna & $\begin{array}{l}\text { Biesinger and } \\
\text { Christensen } 1972\end{array}$ \\
\hline SAV: & 6098 & & \\
\hline A-C ratios: & 2.98 & Daphnia magna & $\begin{array}{l}\text { Biesinger and } \\
\text { Christensen } 1972\end{array}$ \\
\hline SACR: & 9.83 & & \\
\hline SCV: & 620 & & \\
\hline \multicolumn{4}{|l|}{ Thallium } \\
\hline Acute values: & $\begin{array}{r}2180 \\
910 \\
1800 \\
132,000 \\
121,000\end{array}$ & $\begin{array}{l}\text { Daphnia magna } \\
\text { Daphnia magna } \\
\text { Fathead minnow } \\
\text { Bluegill } \\
\text { Bluegill }\end{array}$ & $\begin{array}{l}\text { EPA 1980bb } \\
\text { Kimball n.d. } \\
\text { ibid. } \\
\text { EPA 1980bb } \\
\text { ibid. }\end{array}$ \\
\hline SAV: & 164 & & \\
\hline A-C ratios: & $\begin{array}{r}6.7 \\
32 \\
3.5\end{array}$ & $\begin{array}{l}\text { Daphnia magna } \\
\text { Fathead minnow } \\
\text { Sheepshead minnow }\end{array}$ & $\begin{array}{l}\text { Kimball n.d. } \\
\text { ibid } \\
\text { EPA 1980bb }\end{array}$ \\
\hline SACR: & 9.08 & & \\
\hline SCV: & 18.0 & & \\
\hline
\end{tabular}




\section{A-8}

Table A.1. (continued)

\begin{tabular}{|c|c|c|c|}
\hline Chemical Name/Data type & Value & Species & Source \\
\hline \multicolumn{4}{|l|}{ Tin } \\
\hline Acute values: & 55,000 & Daphnia magna & $\begin{array}{l}\text { Biesinger and } \\
\text { Christensen } 1972\end{array}$ \\
\hline SAV: & 2683 & & \\
\hline A-C ratios: & 151 & Daphnia magna & $\begin{array}{l}\text { Biesinger and } \\
\text { Christensen } 1972\end{array}$ \\
\hline SACR: & 36.4 & & \\
\hline SCV: & 73.7 & & \\
\hline \multicolumn{4}{|l|}{ Uranium } \\
\hline Acute values: & $\begin{array}{r}2800 \\
3100 \\
3700 \\
135,000\end{array}$ & $\begin{array}{l}\text { Fathead minnow } \\
\text { Fathead minnow } \\
\text { Fathead minnow } \\
\text { Fathead minnow }\end{array}$ & $\begin{array}{l}\text { Cushman et al. } 1977 \\
\text { ibid. } \\
\text { ibid. } \\
\text { ibid. }\end{array}$ \\
\hline SAV: & 33.5 & & \\
\hline SACR: & 17.9 & & \\
\hline SCV: & 1.87 & & \\
\hline \multicolumn{4}{|l|}{ Vanadium } \\
\hline Acute values: & $\begin{array}{r}1520 \\
1850 \\
7000 \\
11,200 \\
4060\end{array}$ & $\begin{array}{l}\text { Daphnia magna } \\
\text { Fathead minnow } \\
\text { Brook trout } \\
\text { Flagfish } \\
\text { Daphnia magna }\end{array}$ & $\begin{array}{l}\text { Kimball n.d. } \\
\text { ibid. } \\
\text { Ernst and Garside } 1987 \\
\text { Holdway and Sprague } \\
1979 \\
\text { Beusen and Neven } 1987\end{array}$ \\
\hline SAV: & 284 & & \\
\hline A-C ratios: & 10.88 & Fathead minnow & Kimball n.d. \\
\hline & 140 & Flagfish & $\begin{array}{l}\text { Holdway and Sprague } \\
1979\end{array}$ \\
\hline & 2.137 & Daphnia magna & Beusen and Neven 1987 \\
\hline Final ACR: & 14.8 & & \\
\hline SAV/FACR: & 19.1 & & \\
\hline
\end{tabular}




\section{A-9}

Table A.1. (continued)

\begin{tabular}{|c|c|c|c|}
\hline Chemical Name/Data type & Value & Species & Source \\
\hline \multicolumn{4}{|l|}{ Zirconium } \\
\hline Acute values: & $\begin{array}{r}14,000 \\
18,000 \\
115,000 \\
240,000 \\
15,000 \\
270,000\end{array}$ & $\begin{array}{l}\text { Fathead minnow } \\
\text { Fathead minnow } \\
\text { Fathead minnow } \\
\text { Fathead minnow } \\
\text { Bluegill } \\
\text { Bluegill }\end{array}$ & $\begin{array}{l}\text { Cushman et al. } 1977 \\
\text { ibid. } \\
\text { ibid. } \\
\text { ibid. } \\
\text { ibid. } \\
\text { ibid. }\end{array}$ \\
\hline SAV: & 982 & & \\
\hline SACR: & 17.9 & & \\
\hline scv: & 54.9 & & \\
\hline \multicolumn{4}{|c|}{ ORGANICS } \\
\hline \multicolumn{4}{|l|}{ Acetone } \\
\hline Acute values: & $\begin{array}{r}8,300,000 \\
1,300,000 \\
8,140,000 \\
7,310,000 \\
5,540,000 \\
13,500,000 \\
12,600,000 \\
13,300,000 \\
12,100,000 \\
8,800,000 \\
7,460,000 \\
7,810,000\end{array}$ & $\begin{array}{l}\text { Bluegill } \\
\text { Mosquitofish } \\
\text { Fathead minnow } \\
\text { Fathead minnow } \\
\text { Rainbow trout } \\
\text { Daphnia magna } \\
\text { Daphnia magna } \\
\text { Daphnia magna } \\
\text { Daphnia magna } \\
\text { Daphnia pulex } \\
\text { Daphnia cucullata } \\
\text { Daphnia cucullata }\end{array}$ & $\begin{array}{l}\text { (AQUIRE) } \\
\text { ibid. } \\
\text { ibid. } \\
\text { ibid. } \\
\text { ibid. } \\
\text { ibid. } \\
\text { ibid. } \\
\text { ibid. } \\
\text { ibid. } \\
\text { ibid. } \\
\text { ibid. } \\
\text { ibid. }\end{array}$ \\
\hline SAV: & 200,000 & & \\
\hline SACR: & 17.9 & & \\
\hline SCV: & 11,173 & & \\
\hline \multicolumn{4}{|l|}{ Anthracene } \\
\hline Acute values: & $\begin{array}{r}11.92 \\
2.78\end{array}$ & $\begin{array}{l}\text { Sunfish } \\
\text { Bluegill }\end{array}$ & $\begin{array}{l}\text { Oris and Giesy } 1985 \\
\text { ibid. }\end{array}$ \\
\hline SAV: & 0.024 & & \\
\hline SACR: & 17.9 & & \\
\hline SCV: & 0.0013 & & \\
\hline
\end{tabular}


A-10

Table A.1. (continued)

\begin{tabular}{|c|c|c|c|}
\hline Chemical Name/Data type & Value & Species & Source \\
\hline \multicolumn{4}{|l|}{ Benzene } \\
\hline Acute values: & $\begin{array}{r}203,000 \\
400,000 \\
620,000 \\
412,000 \\
412,000 \\
356,000 \\
356,000 \\
345,000 \\
265,000 \\
5300 \\
34,420 \\
33,470 \\
32,000 \\
36,600 \\
386,000 \\
22,490\end{array}$ & $\begin{array}{l}\text { Daphnia magna } \\
\text { Daphnia magna } \\
\text { Daphnia magna } \\
\text { Daphnia magna } \\
\text { Daphnia magna } \\
\text { Daphnia magna } \\
\text { Daphnia magna } \\
\text { Daphnia pulex } \\
\text { Daphnia pulex } \\
\text { Rainbow trout } \\
\text { Goldfish } \\
\text { Fathead minnow } \\
\text { Fathead minnow } \\
\text { Guppy } \\
\text { Mosquitofish } \\
\text { Bluegill }\end{array}$ & $\begin{array}{l}\text { EPA 1980d } \\
\text { Canton and Adema } 1978 \\
\text { ibid. } \\
\text { ibid. } \\
\text { ibid. } \\
\text { ibid. } \\
\text { ibid. } \\
\text { ibid. } \\
\text { ibid. } \\
\text { DeGraeve et al. } 1980 \\
\text { EPA 1980d } \\
\text { ibid. } \\
\text { ibid. } \\
\text { ibid. } \\
\text { ibid. } \\
\text { ibid. }\end{array}$ \\
\hline SAV: & 815.4 & & \\
\hline SACR: & 17.9 & & \\
\hline scv: & 45.5 & & \\
\hline \multicolumn{4}{|l|}{ Benzidene } \\
\hline Acute values: & $\begin{array}{r}7400 \\
4350 \\
2500 \\
16,200\end{array}$ & $\begin{array}{l}\text { Rainbow trout } \\
\text { Lake trout } \\
\text { Red shiner } \\
\text { Flagfish }\end{array}$ & $\begin{array}{l}\text { EPA 1980c } \\
\text { ibid. } \\
\text { ibid. } \\
\text { ibid. }\end{array}$ \\
\hline SAV: & 69.1 & & \\
\hline SACR: & 17.9 & & \\
\hline ScV: & 3.86 & & \\
\hline \multicolumn{4}{|l|}{ Benzo(a)anthracene } \\
\hline Acute values: & $10^{\circ}$ & Daphnia pulex & Trucco et al. 1983 \\
\hline SAV: & 0.49 & & \\
\hline SACR: & 17.9 & & \\
\hline SCV: & 0.027 & & \\
\hline
\end{tabular}




\section{A-11}

Table A.1. (continued)

\begin{tabular}{|c|c|c|c|}
\hline Chemical Name/Data type & Value & Species & Source \\
\hline \multicolumn{4}{|l|}{ Benzo(a)pyrene } \\
\hline Acute values: & $5^{e}$ & Daphnia pulex & Trucco et al. 1983 \\
\hline SAV: & 0.24 & & \\
\hline SACR: & 17.9 & & \\
\hline scv: & 0.014 & & \\
\hline \multicolumn{4}{|l|}{ Benzoic acid } \\
\hline Acute values: & 180,000 & Mosquitofish & (AQUIRE) $^{e}$ \\
\hline SAV: & 743 & & \\
\hline SACR: & 17.9 & & \\
\hline SCV: & 41.6 & & \\
\hline \multicolumn{4}{|l|}{ Benzyl alcohol } \\
\hline Acute values: & $\begin{array}{r}10,000 \\
460,000\end{array}$ & $\begin{array}{l}\text { Bluegill } \\
\text { Fathead minnow }\end{array}$ & $\begin{array}{l}\text { Dawson et al. } 1977 \\
\text { (AQUIRE) }\end{array}$ \\
\hline SAV: & 1047 & & \\
\hline SACR: & 17.9 & & \\
\hline SCV: & 58 & & \\
\hline \multicolumn{4}{|l|}{ BHC (other than Lindane) } \\
\hline Acute values: & $\begin{array}{r}1000 \\
800\end{array}$ & $\begin{array}{l}\text { Daphnia magna } \\
\text { Daphnia magna }\end{array}$ & $\begin{array}{l}\text { (AQUIRE)e } \\
\text { ibid. }\end{array}$ \\
\hline SAV: & 43.6 & & \\
\hline SACR: & 17.9 & & \\
\hline scV: & 2.44 & & \\
\hline
\end{tabular}


A-12

Table A.1. (continued)

\begin{tabular}{|c|c|c|c|}
\hline Chemical Name/Data type & Value & Species & Source \\
\hline \multicolumn{4}{|l|}{ Bis(2-ethylhexyl)phthalate } \\
\hline \multirow[t]{7}{*}{ Acute values: } & 2000 & Daphnia magna & $\begin{array}{l}\text { Adams and Heidolph } \\
1985\end{array}$ \\
\hline & 11,000 & Daphnia magna & Le Blanc 1980 \\
\hline & 133 & Daphnia pulex & Passino and Smith 1987 \\
\hline & $>100,000$ & Channel catfish & $\begin{array}{l}\text { Mayer and Ellersieck } \\
1986\end{array}$ \\
\hline & $>100,000$ & Coho salmon & ibid. \\
\hline & $>100,000$ & Bluegill & ibid. \\
\hline & $>32,000$ & Scud & ibid. \\
\hline SAV: & 286 & & \\
\hline A-C ratios: & 2.19 & Daphnia magna & $\begin{array}{l}\text { Adams and Heidolph } \\
1985\end{array}$ \\
\hline SACR: & 8.88 & & \\
\hline scV: & 32.2 & & \\
\hline \multicolumn{4}{|l|}{ 2-Butanone } \\
\hline \multirow[t]{3}{*}{ Acute values: } & $5,600,000$ & Mosquitofish & (AQUIRE) ${ }^{\mathrm{e}}$ \\
\hline & $3,200,000$ & Fathead minnow & Veith et al. 1983 \\
\hline & $5,091,000$ & Daphnia magna & Randall and Knopp 1980 \\
\hline SAV: & 372,093 & & \\
\hline SACR: & 17.9 & & \\
\hline scV: & 20,787 & & \\
\hline \multicolumn{4}{|l|}{ Carbon disulfide } \\
\hline Acute values: & $\begin{array}{r}2100 \\
135,000\end{array}$ & $\begin{array}{l}\text { Daphnia magna } \\
\text { Mosquitofish }\end{array}$ & $\begin{array}{l}\text { Van Leeuwen et al. } 1985 \\
\text { (AQUIRE) }\end{array}$ \\
\hline SAV: & 159 & & \\
\hline SACR: & 17.9 & & \\
\hline scv: & 8.89 & & \\
\hline
\end{tabular}




\section{A-13}

Table A.1. (continued)

\begin{tabular}{|c|c|c|c|}
\hline Chemical Name/Data type & Value & Species & Source \\
\hline \multicolumn{4}{|l|}{ Carbon tetrachloride } \\
\hline Acute values: & $\begin{array}{r}35,200 \\
43,100 \\
125,000 \\
27,300\end{array}$ & $\begin{array}{l}\text { Daphnia magna } \\
\text { Fathead minnow } \\
\text { Bluegill } \\
\text { Bluegill }\end{array}$ & $\begin{array}{l}\text { EPA 1980h } \\
\text { Kimball n.d. } \\
\text { EPA 1980h } \\
\text { ibid. }\end{array}$ \\
\hline SAV: & 4093 & & \\
\hline SACR: & 17.9 & & \\
\hline SCV: & 229 & & \\
\hline \multicolumn{4}{|l|}{ Chlorobenzene } \\
\hline Acute values: & $\begin{array}{l}86,000 \\
51,620 \\
33,930 \\
29,120 \\
33,930 \\
45,530 \\
24,000 \\
15,900\end{array}$ & $\begin{array}{l}\text { Daphnia magna } \\
\text { Goldfish } \\
\text { Fathead minnow } \\
\text { Fathead minnow } \\
\text { Fathead minnow } \\
\text { Guppy } \\
\text { Bluegill } \\
\text { Bluegill }\end{array}$ & $\begin{array}{l}\text { EPA } 1980 \mathrm{j} \\
\text { ibid. } \\
\text { ibid. } \\
\text { ibid. } \\
\text { ibid. } \\
\text { ibid. } \\
\text { ibid. } \\
\text { ibid. }\end{array}$ \\
\hline SAV: & 2271 & & \\
\hline SACR: & 17.9 & & \\
\hline SCV: & 127 & & \\
\hline \multicolumn{4}{|l|}{ Chloroform } \\
\hline Acute values: & $\begin{array}{r}28,900 \\
66,800 \\
43,800 \\
115,000 \\
100,000\end{array}$ & $\begin{array}{l}\text { Daphnia magna } \\
\text { Rainbow trout } \\
\text { Rainbow trout } \\
\text { Bluegill } \\
\text { Bluegill }\end{array}$ & $\begin{array}{l}\text { EPA } 19801 \\
\text { ibid. } \\
\text { ibid. } \\
\text { ibid. } \\
\text { ibid. }\end{array}$ \\
\hline SAV: & 3360 & & \\
\hline SACR: & 17.9 & & \\
\hline SCV: & 188 & & \\
\hline
\end{tabular}


A-14

Table A.1. (continued)

\begin{tabular}{|c|c|c|c|}
\hline Chemical Name/Data type & Value & Species & Source \\
\hline \multicolumn{4}{|l|}{ p,p'DDD } \\
\hline Acute values: & $\begin{array}{r}45 \\
16 \\
0.6 \\
0.9 \\
0.7 \\
2.4 \\
140 \\
70 \\
4400 \\
1500 \\
42 \\
14 \\
42 \\
740\end{array}$ & $\begin{array}{l}\text { Daphnia magna } \\
\\
\text { Daphnia magna } \\
\text { Daphnia pulex } \\
\text { Simocephalus } \\
\text { serrulatus } \\
\text { Simocephalus } \\
\text { serrulatus } \\
\text { Cypridopsis vidula } \\
\text { Isopod } \\
\text { Scud } \\
\text { Scud } \\
\text { Grass shrimp } \\
\text { Grass shrimp } \\
\text { Fowler's toad } \\
\text { Rainbow trout } \\
\text { Fathead minnow } \\
\text { Channel catfish } \\
\text { Largemouth bass } \\
\text { Walleye } \\
\text { Bluegill } \\
\text { Turbellarian }\end{array}$ & $\begin{array}{l}\text { Mayer and Ellersieck } \\
1986 \\
\text { ibid. } \\
\text { ibid. } \\
\text { ibid. } \\
\text { ibid. } \\
\text { ibid. } \\
\text { ibid. } \\
\text { ibid. } \\
\text { ibid. } \\
\text { ibid. } \\
\text { ibid. } \\
\text { ibid. } \\
\text { ibid. } \\
\text { ibid. } \\
\text { ibid. } \\
\text { ibid. } \\
\text { ibid. } \\
\text { ibid. } \\
\text { EPA } 1980 \mathrm{~m}\end{array}$ \\
\hline SAV: & 0.18 & & \\
\hline SACR: & 17.9 & & \\
\hline SCV: & 0.010 & & \\
\hline \multicolumn{4}{|l|}{ DDT } \\
\hline FAV & 1.1 & & \\
\hline Acute-Chronic ratios & 65 & Fathead minnow & Jarvinen et al. 1977 \\
\hline FACR & 27.5 & & \\
\hline FAV/FACR & 0.04 & & \\
\hline \multicolumn{4}{|l|}{ Decane } \\
\hline Acute values: & 18,000 & Daphnia magna & Le Blanc 1980 \\
\hline SAV: & 878 & & \\
\hline SACR: & 17.9 & & \\
\hline SCV: & 49 & & \\
\hline
\end{tabular}




\section{A-15}

Table A.1. (continued)

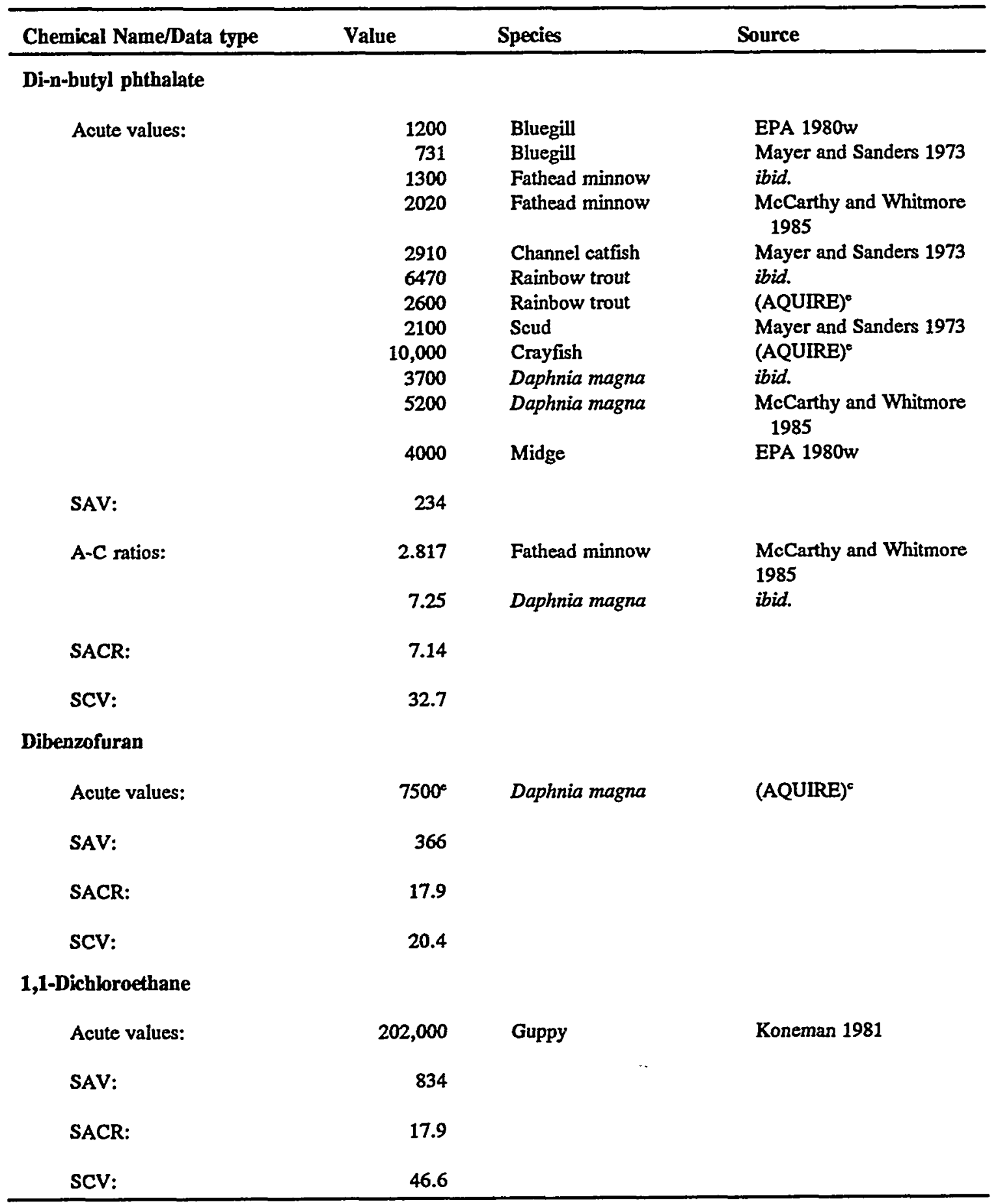




\section{A-16}

Table A.1. (continued)

\begin{tabular}{|c|c|c|c|}
\hline Chemical Name/Data type & Value & Species & Source \\
\hline \multicolumn{4}{|l|}{ 1,2-Dichloroethane } \\
\hline Acute values: & $\begin{array}{l}270,000 \\
116,000 \\
550,000 \\
431,000\end{array}$ & $\begin{array}{l}\text { Daphnia magna } \\
\text { Fathead minnow } \\
\text { Bluegill } \\
\text { Bluegill }\end{array}$ & $\begin{array}{l}\text { Richter et al. } 1983 \\
\text { Ahmed et al. } 1984 \\
\text { EPA 1980k } \\
\text { ibid. }\end{array}$ \\
\hline SAV: & 13,500 & & \\
\hline A-C ratios: & $\begin{array}{r}5.9 \\
17.76\end{array}$ & $\begin{array}{l}\text { Fathead minnow } \\
\text { Daphnia magna }\end{array}$ & $\begin{array}{l}\text { Ahmed et al. } 1984 \\
\text { Richter et al. } 1983\end{array}$ \\
\hline SACR: & 12.3 & & \\
\hline SCV: & 1100 & & \\
\hline \multicolumn{4}{|l|}{ 1,1-Dichloroethene } \\
\hline Acute values: & $\begin{array}{r}11,600 \\
79,000 \\
169,000 \\
108,000 \\
73,900\end{array}$ & $\begin{array}{l}\text { Daphnia magna } \\
\text { Daphnia magna } \\
\text { Fathead minnow } \\
\text { Fathead minnow } \\
\text { Bluegill }\end{array}$ & $\begin{array}{l}\text { EPA 1980n } \\
\text { ibid. } \\
\text { ibid. } \\
\text { ibid. } \\
\text { ibid. }\end{array}$ \\
\hline SAV: & 3520 & & \\
\hline SACR: & 17.9 & & \\
\hline SCV: & 196 & & \\
\hline \multicolumn{4}{|l|}{ 1,2-Dichloroethene } \\
\hline Acute values: & 135,000 & Bluegill & EPA 1980n \\
\hline SAV: & 558 & & \\
\hline SACR: & 17.9 & & \\
\hline SCV: & 31.2 & & \\
\hline \multicolumn{4}{|l|}{ 1,3-Dichloropropene (total) } \\
\hline Acute values: & $\begin{array}{l}6150 \\
6060\end{array}$ & $\begin{array}{l}\text { Daphnia magna } \\
\text { Bluegill }\end{array}$ & $\begin{array}{l}\text { EPA } 19800 \\
\text { ibid. }\end{array}$ \\
\hline SAV: & 459 & & \\
\hline SACR: & 17.9 & & \\
\hline SCV: & 25.6 & & \\
\hline
\end{tabular}




\section{A-17}

Table A.1. (continued)

\begin{tabular}{|c|c|c|c|}
\hline Chemical Name/Data type & Value & Species & Source \\
\hline \multicolumn{4}{|l|}{ Diethyl phthalate } \\
\hline Acute values: & $\begin{array}{l}98,200 \\
52,000\end{array}$ & $\begin{array}{l}\text { Bluegill } \\
\text { Daphnia magna }\end{array}$ & $\begin{array}{l}\text { EPA 1980w } \\
\text { ibid. }\end{array}$ \\
\hline SAV: & 3947 & & \\
\hline SACR: & 17.9 & & \\
\hline SCV: & 220 & & \\
\hline \multicolumn{4}{|l|}{ Ethyl benzene } \\
\hline Acute values: & $\begin{array}{r}75,000 \\
94,440 \\
48,510 \\
42,330 \\
97,100 \\
32,000 \\
155,000\end{array}$ & $\begin{array}{l}\text { Daphnia magna } \\
\text { Goldfish } \\
\text { Fathead minnow } \\
\text { Fathead minnow } \\
\text { Guppy } \\
\text { Bluegill } \\
\text { Bluegill }\end{array}$ & $\begin{array}{l}\text { EPA 1980p } \\
\text { ibid. } \\
\text { ibid. } \\
\text { ibid. } \\
\text { ibid. } \\
\text { ibid. } \\
\text { ibid. }\end{array}$ \\
\hline SAV: & 6971 & & \\
\hline SACR: & 17.9 & & \\
\hline scv: & 389 & & \\
\hline \multicolumn{4}{|l|}{ Heptachlor } \\
\hline Final Acute Value: & 0.52 & & EPA 1980r \\
\hline Acute-Chronic ratios & $\begin{array}{r}80 \\
3.9\end{array}$ & $\begin{array}{l}\text { Fathead minnow } \\
\text { Sheepshead minnow }\end{array}$ & $\begin{array}{l}\text { ibid. } \\
\text { ibid. }\end{array}$ \\
\hline SACR & 17.69 & & \\
\hline scV & 0.029 & & \\
\hline \multicolumn{4}{|l|}{ Hexane } \\
\hline Acute values: & $\begin{array}{r}150,000^{3} \\
4,480,000^{3}\end{array}$ & $\begin{array}{l}\text { Golden orfe } \\
\text { Golden orfe }\end{array}$ & $\begin{array}{l}\text { (AQUIRE)e } \\
\text { ibid. }\end{array}$ \\
\hline SAV: & 3387 & & \\
\hline SACR: & 17.9 & & \\
\hline ScV: & 189 & & \\
\hline
\end{tabular}




\section{A-18}

Table A.1. (continued)

\begin{tabular}{|c|c|c|c|}
\hline Chemical Name/Data type & Value & Species & Source \\
\hline \multicolumn{4}{|l|}{ 2-Hexanone } \\
\hline Acute values: & $428,000^{8}$ & Fathead minnow & $(A Q U I R E)^{e}$ \\
\hline SAV: & 1768 & & \\
\hline SACR: & 17.9 & & \\
\hline scV & 98.8 & & \\
\hline \multicolumn{4}{|l|}{ 1-Methylnaphthalene } \\
\hline Acute values: & 9000 & Fathead minnow & (AQUIRE) $^{e}$ \\
\hline SAV: & 37.2 & & \\
\hline SACR: & 17.9 & & \\
\hline scv: & 2.08 & & \\
\hline \multicolumn{4}{|l|}{ 4-Methyl-2-pentanone } \\
\hline Acute values: & 509,000 & Fathead minnow & Veith et al. 1983 \\
\hline SAV: & 2103 & & \\
\hline A-C ratios: & 6.58 & Fathead minnow & Call et al. 1985 \\
\hline SACR: & 12.8 & & \\
\hline scv: & 164 & & \\
\hline
\end{tabular}


A-19

Table A.1. (continued)

\begin{tabular}{|c|c|c|c|}
\hline Chemical Name/Data type & Value & Species & Source \\
\hline \multicolumn{4}{|l|}{ 2-Methylphenol } \\
\hline \multirow[t]{18}{*}{ Acute values: } & 12,550 & Fathead minnow & $\begin{array}{l}\text { Pickering and Henderson } \\
1966\end{array}$ \\
\hline & 13,420 & Fathead minnow & ibid. \\
\hline & 18,200 & Fathead minnow & DeGraeve et al. 1980 \\
\hline & 20,780 & Bluegill & $\begin{array}{l}\text { Pickering and Henderson } \\
1966\end{array}$ \\
\hline & 23,250 & Goldfish & ibid. \\
\hline & 8400 & Rainbow trout & DeGraeve et al. 1980 \\
\hline & 17,400 & $\begin{array}{l}\text { Daphnia } \\
\text { cucullata }\end{array}$ & Canton and Adema 1978 \\
\hline & 15,500 & $\begin{array}{l}\text { Daphnia } \\
\text { cucullata }\end{array}$ & ibid. \\
\hline & 9800 & Daphnia magna & ibid. \\
\hline & 8600 & Daphnia magna & ibid. \\
\hline & 23,800 & Daphnia magna & ibid. \\
\hline & 23,100 & Daphnia magna & ibid. \\
\hline & 15,100 & Daphnia magna & ibid. \\
\hline & 15,800 & Daphnia magna & (AQUIRE) ${ }^{e}$ \\
\hline & 5000 & Daphnia magna & Parkhurst et al. 1979 \\
\hline & 14,000 & Daphnia magna & Canton and Adema 1978 \\
\hline & 10,800 & Daphnia pulex & Adema 1978 \\
\hline & 8500 & Daphnia pulex & Canton and Adema 1978 \\
\hline SAV: & 1292 & & \\
\hline SACR: & 17.9 & & \\
\hline SCV: & 72.2 & & \\
\hline \multicolumn{4}{|l|}{ Methylene chloride } \\
\hline \multirow[t]{4}{*}{ Acute values: } & 220,000 & Bluegill & Buccafusco et al. 1981 \\
\hline & 193,000 & Fathead minnow & Alexander et al. 1978 \\
\hline & 502,000 & Fathead minnow & Dill et al. 1987 \\
\hline & 220,000 & Daphnia magna & LeBlanc 1980 \\
\hline SAV: & 25,581 & & \\
\hline A-C ratios: & 4.65 & Fathead minnow & Dill et al. 1987 \\
\hline SACR: & 11.4 & & \\
\hline SCV: & 2243 & & \\
\hline
\end{tabular}


A-20

Table A.1. (continued)

\begin{tabular}{|c|c|c|c|}
\hline Chemical Name/Data type & Value & Species & Source \\
\hline \multicolumn{4}{|l|}{ Naphthalene } \\
\hline Acute values: & $\begin{array}{r}8570 \\
2300 \\
4900 \\
8900 \\
150,000\end{array}$ & $\begin{array}{l}\text { Daphnia magna } \\
\text { Rainbow trout } \\
\text { Fathead minnow } \\
\text { Fathead minnow } \\
\text { Mosquitofish }\end{array}$ & $\begin{array}{l}\text { EPA } 1980 t \\
\text { DeGraeve et al } 1980 \\
\text { ibid. } \\
\text { ibid. } \\
\text { EPA 1980t }\end{array}$ \\
\hline SAV: & 353 & & \\
\hline A-C ratios: & 10.65 & Fathead minnow & DeGraeve et al. 1982 \\
\hline SACR: & 15.1 & & \\
\hline SCV: & 23.4 & & \\
\hline \multicolumn{4}{|l|}{ 4-Nitrophenol } \\
\hline Acute values: & $\begin{array}{r}8300 \\
59,000 \\
62,000 \\
41,000 \\
7900 \\
15,000 \\
22,000 \\
8400 \\
20,000 \\
7680 \\
13,200\end{array}$ & $\begin{array}{l}\text { Bluegill } \\
\text { Fathead minnow } \\
\text { Fathead minnow } \\
\text { Fathead minnow } \\
\text { Rainbow trout } \\
\text { Channel catfish } \\
\text { Daphnia magna } \\
\text { Daphnia magna } \\
\text { Daphnia magna } \\
\text { Daphnia magna } \\
\text { River snail }\end{array}$ & $\begin{array}{l}\text { Buccafusco et al. } 1981 \\
\text { (AQUIRE) }^{e} \\
\text { ibid. } \\
\text { ibid. } \\
\text { ibid. } \\
\text { ibid. } \\
\text { LeBlanc } 1980 \\
\text { Kopperman et al. } 1974 \\
\text { Randall and Knopp } 1974 \\
\text { Keen and Baillod } 1985 \\
\text { (Acquire) }^{e}\end{array}$ \\
\hline SAV: & 1580 & & \\
\hline A-C ratios: & 2.83 & Daphnia magna & Francis et al. $1986^{f}$ \\
\hline SACR: & 9.68 & & \\
\hline SCV: & 163 & & \\
\hline \multicolumn{4}{|l|}{ N-Nitrosodiphenylamine } \\
\hline Acute values: & $\begin{array}{l}5800 \\
7800\end{array}$ & $\begin{array}{l}\text { Bluegill } \\
\text { Daphnia magna }\end{array}$ & $\begin{array}{l}\text { Buccafusco et al. } 1981 \\
\text { LeBlanc } 1980\end{array}$ \\
\hline SAV: & 439 & & \\
\hline SACR: & 17.9 & & \\
\hline SCV: & 24.5 & & \\
\hline
\end{tabular}


A-21

Table A.1. (continued)

\begin{tabular}{|c|c|c|c|}
\hline Chemical Name/Data type & Value & Species & Source \\
\hline \multicolumn{4}{|l|}{ 3-Octanone } \\
\hline Acute values: & $\begin{array}{r}80,000^{\circ} \\
517,000^{\circ}\end{array}$ & $\begin{array}{l}\text { Goldfish } \\
\text { Daphnia magna }\end{array}$ & $\begin{array}{l}\text { (AQUIRE) } \\
\text { ibid. }\end{array}$ \\
\hline SAV: & 6060 & & \\
\hline SACR: & 17.9 & & \\
\hline SCV: & 338 & & \\
\hline \multicolumn{4}{|l|}{ PCBs: total } \\
\hline FAV: & 2.0 & & \\
\hline Acute-Chronic Ratios: & $\begin{array}{r}6.4 \\
11.0\end{array}$ & $\begin{array}{l}\text { Fathead minnor } \\
\text { Scud }\end{array}$ & $\begin{array}{l}\text { EPA 1980x } \\
\text { ibid. }\end{array}$ \\
\hline SACR: & 10.8 & & \\
\hline SCV: & 0.19 & & \\
\hline \multicolumn{4}{|l|}{ PCBs: Aroclor 1221} \\
\hline \multicolumn{4}{|l|}{ Acute values: } \\
\hline SAV: & 4.83 & & \\
\hline SACR: & 17.9 & & \\
\hline SCV: & 0.27 & & \\
\hline \multicolumn{4}{|l|}{ PCBs: Aroclor 1232} \\
\hline \multirow[t]{2}{*}{ Acute values: } & 2500 & Cutthroat trout - & Stalling and Mayer 1972 \\
\hline & 1900 & Cutthroat trout & (Acquire) $^{e}$ \\
\hline SAV: & 9.01 & & \\
\hline SACR: & 17.9 & & \\
\hline scV: & 0.50 & & \\
\hline
\end{tabular}


A-22

Table A.1. (continued)

\begin{tabular}{|c|c|c|c|}
\hline Chemical Name/Data type & Value & Species & Source \\
\hline \multicolumn{4}{|l|}{ PCBs: Aroclor 1242} \\
\hline \multirow[t]{5}{*}{ Acute values: } & 73 & Scud & $\begin{array}{l}\text { Nebeker and Puglisi } \\
1974\end{array}$ \\
\hline & 10 & Scud & Mayer et al 1977 \\
\hline & 400 & Damselfly & ibid. \\
\hline & 15 & Fathead minnow & Nebeker et al 1974 \\
\hline & 300 & Fathead minnow & ibid. \\
\hline SAV: & 0.75 & & \\
\hline \multirow[t]{2}{*}{ A-C ratios: } & 14.90 & Scud & $\begin{array}{l}\text { Nebeker and Puglisi } \\
1974\end{array}$ \\
\hline & 7.454 & Fathead minnow & Nebeker et al. 1974 \\
\hline SACR: & 12.5 & & \\
\hline SCV: & 0.06 & & \\
\hline \multicolumn{4}{|l|}{ PCBs: Aroclor 1248} \\
\hline Acute values: & $\begin{array}{l}52 \\
29\end{array}$ & $\begin{array}{l}\text { Scud } \\
\text { Scud }\end{array}$ & $\begin{array}{l}\text { Mayer et al. } 1977 \\
\text { Nebeker and Puglisi } \\
1974\end{array}$ \\
\hline SAV: & 0.16 & & \\
\hline A-C ratios: & 8.788 & Scud & ibid. \\
\hline SACR: & 14.1 & - & \\
\hline SCV: & 0.011 & & \\
\hline \multicolumn{4}{|l|}{ PCBs: Aroclor 1254} \\
\hline Acute values: & $\begin{array}{r}2400 \\
200 \\
7.7\end{array}$ & $\begin{array}{l}\text { Scud } \\
\text { Damselfly } \\
\text { Fathead minnow }\end{array}$ & $\begin{array}{l}\text { Mayer et al. } 1977 \\
\text { ibid. } \\
\text { Nebeker et al. } 1974\end{array}$ \\
\hline SAV: & 0.21 & & \\
\hline A-C ratios: & 2.655 & Fathead minnow & ibid. \\
\hline SACR: & 9.48 & & \\
\hline SCV: & 0.02 & & \\
\hline
\end{tabular}


A-23

Table A.1. (continued)

\begin{tabular}{|c|c|c|c|}
\hline Chemical Name/Data type & Value & Species & Source \\
\hline \multicolumn{4}{|l|}{ PCBs: Aroclor 1260} \\
\hline Acute values: & $\begin{array}{l}60,900 \\
61,000 \\
25,000\end{array}$ & $\begin{array}{l}\text { Cutthroat trout } \\
\text { Cutthroat trout } \\
\text { Cutthroat trout }\end{array}$ & $\begin{array}{l}\text { (AQUIRE)e } \\
\text { ibid. } \\
\text { ibid. }\end{array}$ \\
\hline SAV: & 187 & & \\
\hline SACR: & 17.9 & & \\
\hline scv: & 10.5 & & \\
\hline \multicolumn{4}{|l|}{ 1-Pentanol } \\
\hline Acute values: & $\begin{array}{l}650,000 \\
400,000\end{array}$ & $\begin{array}{l}\text { Bluegill } \\
\text { Rainbow trout }\end{array}$ & $\begin{array}{l}\text { Dawson et al. } 1977 \\
\text { (Acquire) }\end{array}$ \\
\hline SAV: & 6172 & & \\
\hline SACR: & 17.9 & & \\
\hline SCV: & 344 & & \\
\hline \multicolumn{4}{|l|}{ Phenanthrene } \\
\hline Acute values: & $\begin{array}{l}960 \\
\\
490 \\
700 \\
843 \\
734\end{array}$ & $\begin{array}{l}\text { Daphnia pulex } \\
\text { Midge } \\
\text { Daphnia magna } \\
\text { Daphnia magna } \\
\text { Daphnia pulex }\end{array}$ & $\begin{array}{l}\text { Geiger and Buikema } \\
1982 \\
\text { Millemann et al. } 1984 \\
\text { ibid. } \\
\text { Eastmond et al. } 1984 \\
\text { Passino and Smith } 1987\end{array}$ \\
\hline SAV: & 37.1 & & \\
\hline A-C ratios: & 4.8 & Daphnia pulex & $\begin{array}{l}\text { Geiger and Buikema } \\
1982\end{array}$ \\
\hline SACR: & 11.5 & & \\
\hline SCV: & 3.23 & & \\
\hline
\end{tabular}


A-24

Table A.1. (continued)

\begin{tabular}{|c|c|c|c|}
\hline Chemical Name/Data type & Value & Species & Source \\
\hline \multicolumn{4}{|l|}{ Phenol } \\
\hline Acute values: & $\begin{array}{r}248,000 \\
94,000 \\
14,000 \\
\\
36,400 \\
58,100 \\
57,000 \\
\\
122,000 \\
108,000 \\
\\
8032 \\
44,500 \\
35,000 \\
16,700 \\
36,300 \\
26,000 \\
34,900 \\
16,400 \\
19,000\end{array}$ & $\begin{array}{l}\text { Rotifer } \\
\text { Snail } \\
\text { Daphnia } \\
\text { longispina } \\
\text { Daphnia magna } \\
\text { Daphnia pulex } \\
\text { Polyphemus } \\
\text { pediculus } \\
\text { Cyclops vernalis } \\
\text { Mesocyclops } \\
\text { leukarti } \\
\text { Rainbow trout } \\
\text { Goldfish } \\
\text { Fathead minnow } \\
\text { Channel cattish } \\
\text { Flagfish } \\
\text { Mosquitofish } \\
\text { Guppy } \\
\text { Bluegill } \\
\text { Mozambique } \\
\text { mouthbrooder }\end{array}$ & $\begin{array}{l}\text { ibid. } \\
\text { ibid. } \\
\text { ibid. } \\
\text { ibid. } \\
\text { ibid. } \\
\text { ibid. } \\
\text { ibid. } \\
\text { ibid. } \\
\text { ibid. } \\
\text { ibid. } \\
\text { ibid. } \\
\text { ibid. } \\
\text { ibid. } \\
\text { ibid. }\end{array}$ \\
\hline SAV: & 2008 & & \\
\hline A-C ratios: & $\begin{array}{l}14.06 \\
18.19\end{array}$ & $\begin{array}{l}\text { Fathead minnow } \\
\text { Fathead minnow }\end{array}$ & $\begin{array}{l}\text { Holcombe et al. } 1982^{f} \\
\text { DeGraeve et al. } 1980\end{array}$ \\
\hline SACR: & 17.2 & & \\
\hline sCV: & 117 & & \\
\hline \multicolumn{4}{|l|}{ 2-Propanol } \\
\hline Acute values: & $\begin{array}{r}10,400 \\
9640\end{array}$ & $\begin{array}{l}\text { Fathead minnow } \\
\text { Fathead minnow }\end{array}$ & $\begin{array}{l}\text { Veith et al.1983 } \\
\text { ibid. }\end{array}$ \\
\hline SAV: & 41.4 & & \\
\hline SACR: & 17.9 & & \\
\hline SCV: & 2.31 & & \\
\hline
\end{tabular}


Table A.1. (continued)

\begin{tabular}{|c|c|c|c|}
\hline Chemical Name/Data type & Value & Species & Source \\
\hline \multicolumn{4}{|l|}{ 1,1,2,2-Tetrachloroethane } \\
\hline Acute values: & $\begin{array}{r}21,000 \\
20,400 \\
62,000 \\
9320 \\
18,480\end{array}$ & $\begin{array}{l}\text { Bluegill } \\
\text { Fathead minnow } \\
\text { Daphnia magna } \\
\text { Daphnia magna } \\
\text { Flagfish }\end{array}$ & $\begin{array}{l}\text { Buccafusco et al. } 1981 \\
\text { Walbridge et al. } 1983 \\
\text { Ahmed et al. } 1984 \\
\text { EPA 1980k } \\
\text { Smith et al. } 1991\end{array}$ \\
\hline SAV: & 3698 & & \\
\hline A-C ratios: & $\begin{array}{r}8.46 \\
6.289 \\
2.56\end{array}$ & $\begin{array}{l}\text { Fathead minnow } \\
\text { Daphnia magna } \\
\text { Flagfish }\end{array}$ & $\begin{array}{l}\text { Ahmed et al. } 1984 \\
\text { Richter et al. } 1983 \\
\text { Smith et al. } 1991\end{array}$ \\
\hline SACR: & 5.14 & & \\
\hline SCV: & 719 & & \\
\hline \multicolumn{4}{|l|}{ Tetrachloroethene } \\
\hline Acute values: & $\begin{array}{r}8500 \\
17,700 \\
30,840 \\
\\
4990 \\
13,460 \\
21,400 \\
12,900 \\
8430\end{array}$ & $\begin{array}{l}\text { Daphnia magna } \\
\text { Daphnia magna } \\
\text { Tanytarsus } \\
\text { dissimilis } \\
\text { Rainbow trout } \\
\text { Fathead minnow } \\
\text { Fathead minnow } \\
\text { Bluegill } \\
\text { Flagfish }\end{array}$ & $\begin{array}{l}\text { Richter et al. } 1983 \\
\text { Ahmed et al. } 1984 \\
\text { Call et al. } 1983 \mathrm{~b} \\
\text { Ahmed et al. } 1984 \\
\text { ibid. } \\
\text { Alexander et al. } 1978 \\
\text { EPA 1980aa } \\
\text { Smith et al. } 1991\end{array}$ \\
\hline SAV: & 998 & & \\
\hline A-C ratios: & $\begin{array}{r}16.02 \\
11.35 \\
2.78\end{array}$ & $\begin{array}{l}\text { Fathead minnow } \\
\text { Daphnia magna } \\
\text { Flagfish }\end{array}$ & $\begin{array}{l}\text { Ahmed et al. } 1984 \\
\text { Richter et al. } 1983 \\
\text { Smith et al. } 1991\end{array}$ \\
\hline SACR: & 7.97 & & \\
\hline sCV: & 125 & & \\
\hline
\end{tabular}




\section{A-26}

Table A.1. (continued)

\begin{tabular}{|c|c|c|c|}
\hline Chemical Name/Data type & Value & Species & Source \\
\hline \multicolumn{4}{|l|}{ Toluene } \\
\hline Acute values: & $\begin{array}{r}60,000 \\
313,000 \\
22,800 \\
57,680 \\
34,270 \\
42,330 \\
59,300 \\
24,000 \\
17,500\end{array}$ & $\begin{array}{l}\text { Daphnia magna } \\
\text { Daphnia magna } \\
\text { Goldfish } \\
\text { Goldfish } \\
\text { Fathead minnow } \\
\text { Fathead minnow } \\
\text { Guppy } \\
\text { Bluegill } \\
\text { Bluegill }\end{array}$ & $\begin{array}{l}\text { EPA 1980cc } \\
\text { ibid. } \\
\text { ibid. } \\
\text { ibid. } \\
\text { ibid. } \\
\text { ibid. } \\
\text { ibid. } \\
\text { ibid. } \\
\text { ibid. }\end{array}$ \\
\hline SAV: & 3153 & & \\
\hline SACR: & 17.9 & & \\
\hline SCV: & 176 & & \\
\hline \multicolumn{4}{|l|}{ 1,1,1-Trichloroethane } \\
\hline Acute values: & $\begin{array}{r}40,000 \\
52,800 \\
105,000\end{array}$ & $\begin{array}{l}\text { Bluegill } \\
\text { Fathead minnow } \\
\text { Fathead minnow }\end{array}$ & $\begin{array}{l}\text { Buccafusco et al. } 1981 \\
\text { Alexander et al. } 1978 \\
\text { ibid. }\end{array}$ \\
\hline SAV: & 617 & & \\
\hline A-C ratios: & $3.057^{i}$ & Daphnia magna & $\begin{array}{l}\text { Thompson and } \\
\text { Carmichael } 1989\end{array}$ \\
\hline SACR: & 9.9 & & \\
\hline SCV: & 62.1 & & \\
\hline
\end{tabular}


Table A.1. (continued)

\begin{tabular}{|c|c|c|c|}
\hline Chemical Name/Data type & Value & Species & Source \\
\hline \multicolumn{4}{|l|}{ 1,1,2-Trichloroethane } \\
\hline Acute values: & $\begin{array}{r}81,600 \\
18,000 \\
43,000 \\
190,000 \\
170,000 \\
170,000 \\
45,117\end{array}$ & $\begin{array}{l}\text { Fathead minnow } \\
\text { Daphnia magna } \\
\text { Daphnia magna } \\
\text { Daphnia magna } \\
\text { Daphnia magna } \\
\text { Great pond snail } \\
\text { Flagfish }\end{array}$ & $\begin{array}{l}\text { Ahmed et al. } 1984 \\
\text { LeBlane } 1980 \\
\text { Adema } 1978 \\
\text { Richter et al. } 1983 \\
\text { ibid. } \\
\text { Adema and Vink } 1981 \\
\text { Smith et al. } 1991\end{array}$ \\
\hline SAV: & 6941 & & \\
\hline A-C ratios: & $\begin{array}{r}8.691 \\
9.776 \\
1.45\end{array}$ & $\begin{array}{l}\text { Fathead minnow } \\
\text { Daphnia magna } \\
\text { Flagfish }\end{array}$ & $\begin{array}{l}\text { Ahmed et al. } 1984 \\
\text { Richter et al. } 1983 \\
\text { Smith et al. } 1991\end{array}$ \\
\hline SACR: & 4.97 & & \\
\hline SCV: & 1396 & & \\
\hline \multicolumn{4}{|l|}{ Trichloroethene } \\
\hline Acute values: & $\begin{array}{r}85,200 \\
100,000 \\
94,000 \\
41,000 \\
43,000 \\
55,000 \\
56,000 \\
51,000 \\
39,000 \\
40,700 \\
66,800 \\
45,000 \\
44,700 \\
28,280\end{array}$ & $\begin{array}{l}\text { Daphnia magna } \\
\text { Daphnia magna } \\
\text { Daphnia magna } \\
\text { Daphnia magna } \\
\text { Daphnia magna } \\
\text { Daphnia magna } \\
\text { Daphnia magna } \\
\text { Daphnia pulex } \\
\text { Daphnia pulex } \\
\text { Fathead minnow } \\
\text { Fathead minnow } \\
\text { Fathead minnow } \\
\text { Bluegill } \\
\text { Flagfish }\end{array}$ & $\begin{array}{l}\text { EPA 1980dd } \\
\text { Canton and Adema } 1978 \\
\text { ibid. } \\
\text { ibid. } \\
\text { ibid. } \\
\text { ibid. } \\
\text { ibid. } \\
\text { ibid. } \\
\text { ibid. } \\
\text { Alexander et al. } 1978 \\
\text { ibid. } \\
\text { Ahmed et al. } 1984 \\
\text { EPA 1980dd } \\
\text { Smith et al. } 1991\end{array}$ \\
\hline SAV: & 4350 & & \\
\hline A-C ratios: & 2.558 & Flagfish & Smith et al. 1991 \\
\hline SACR: & 9.3 & & \\
\hline SCV: & 465 & & \\
\hline
\end{tabular}




\section{A-28}

Table A.1. (continued)

\begin{tabular}{|c|c|c|c|}
\hline Chemical Name/Data type & Value & Species & Source \\
\hline \multicolumn{4}{|l|}{ Vinyl acetate } \\
\hline Acute values: & $\begin{array}{l}13,465^{j} \\
18,000 \\
\\
42,330 \\
31,080\end{array}$ & $\begin{array}{l}\text { Fathead minnow } \\
\text { Bluegill } \\
\text { Goldfish } \\
\text { Guppy }\end{array}$ & $\begin{array}{l}\text { (AQUIRE) } \\
\text { Pickering and Henderson } \\
1966 \\
\text { ibid. } \\
\text { ibid. }\end{array}$ \\
\hline SAV: & 372 & & \\
\hline SACR: & 17.9 & & \\
\hline scv: & 20.8 & & \\
\hline \multicolumn{4}{|l|}{ Vingl chloride } \\
\hline Acute values: & $\begin{array}{l}356,000^{3} \\
406,000^{3}\end{array}$ & $\begin{array}{l}\text { Golden orfe } \\
\text { Golden orfe }\end{array}$ & $\begin{array}{l}\text { (AQUIRE) } \\
\text { ibid. }\end{array}$ \\
\hline SAV: & 1570 & & \\
\hline SACR: & 17.9 & & \\
\hline scv: & 87.8 & & \\
\hline \multicolumn{4}{|l|}{ Xylene } \\
\hline Acute values: & $\begin{array}{r}780,000 \\
99,500\end{array}$ & $\begin{array}{l}\text { Common carp } \\
\text { Calanoid copepod }\end{array}$ & $\begin{array}{l}\text { (AQUIRE) } \\
\text { ibid. }\end{array}$ \\
\hline SAV: & 1540 & & \\
\hline SACR: & 17.9 & & \\
\hline scV: & 86.2 & & \\
\hline
\end{tabular}

- Secondary Acute Value.

${ }^{b}$ Acute-Chronic ratios.

- Secondary Acute-Chronic Ratio.

'Secondary Chronic Value.

- These acute tests were of a non-standard duration. Standard durations are 48-h for daphnids and midges, and 96-h for all other aquatic animals.

'These reports contained no acute value to accompany the chronic values, so a species mean acute value derived from other available studies was used to calculate the ratio.

These test results are unreliable in that either a test duration was not specified or the experimental methods were not usual or not consistent, but they are the best data available.

${ }^{b}$ Because the list of acute values for phenol is so long, the species mean acute values have been substituted here.

Based on a 17-day LC50 (standard is 48-h).

j Water hardness was varied in this test; a logarithmic regression was performed according to the National Guidelines, and $13,465 \mu \mathrm{g} / \mathrm{l}$ is the intercept value. 
APPENDIX B

METHODS FOR DERIVATION OF TIER II VALUES 
THIS PAGE INTENTIONALLY LEFT BLANK 


\section{METHODS FOR DERIVATION OF TIER II VALUES}

Tier II values are derived if fewer than eight of the acute data requirements or three chronic data requirements presented in EPA (1993a) are met. The eight acute data requirements include:

a. The family Salmonidae in the class Osteichthyes

b. One other family (preferably a commercially, or recreationally important, warmwater species) in the class Osteichthyes (e.g., bluegill, channel catfish, etc.)

c. A third family in the phylum Chordata (e.g., fish, amphibian, etc.)

d. A planktonic crustacean (e.g., a cladocceran, copepod, etc.)

e. A benthic crustacean (e.g., ostracod, isopod, amphipod, crayfish, etc.)

f. An insect (e.g., mayfly, dragonfly, damselfly, stonefly, caddisfly, mosquito, midge, etc.)

g. A family in a phylum other than Arthropoda or Chordata (e.g., Rotifera, Annelida, Mollusca, etc.)

h. A family in any order of insect or any phylum not already represented

If all of these data requirements are not met, then an FAV is calculated. The FAV is a Tier I criterion, and its derivation is documented in Stephan et al. (1985) and in Appendix A of EPA (1993a). The FAV, however, is used in the derivation of the SCV if the chronic data requirements are not met.

Tier II values, as mentioned previously, are calculated when the data requirements are not met. The first calculation of the Tier II criteria is the SAV. The SAV is derived by taking the lowest genus mean acute value for any of the genera present and dividing it by a Final Acute Value Factor (FAVF). The FAVF is selected from Table B.1 where $n$ is the number of the eight acute data requirements that are satisfied. FAVFs are selected from the two columns depending on whether an LC50 or EC50 for a daphnid is included in the data set.

Once the SAV is calculated, the Secondary Acute-Chronic Ratio (SACR) is derived. If three or more Acute-Chronic Ratios (ACRs) are present, then the SACR is determined by finding the geometric mean of the ACRs. There must be at least three ACRs. If there are not three chronic values from the literature, then a default value of 17.9 (EPA 1991) is used until the total number of ACRs is three. If multiple ACRs are given for the same genus, then the geometric mean of those ACRs must be calculated. This genus mean ACR can then be used in the derivation of the SACR. Therefore, several members of the same genus can only present one value towards the mandatory three. If no ACRs are given, then the SACR is 17.9.

The final calculation for Tier II values is the derivation of an SCV. The SCV is calculated by dividing the FAV or SAV by the SACR. 


\section{B-4}

Table B.1. Factors for estimation of the Tier II values (EPA 1993 and Stephan 1991)

\begin{tabular}{ccc}
\hline Number of LC50s & $\begin{array}{c}\text { Factor for data sets that } \\
\text { include a LC50a for a } \\
\text { daphnid }\end{array}$ & $\begin{array}{c}\text { Factors for data sets that do } \\
\text { not include a LC50 for a } \\
\text { daphnid }^{\mathrm{b}}\end{array}$ \\
\hline 1 & 20.5 & 242 \\
2 & 13.2 & 64.8 \\
3 & 8.6 & 36.2 \\
4 & 6.5 & 20.1 \\
5 & 5.0 & 12.9 \\
7 & 4.0 & 9.2 \\
\hline
\end{tabular}

- All LC50s should be from different families and otherwise should meet the requirements of data used to calculate FAVs (EPA 1993a). Multiple LC50s for a species should be geometrically averaged to generate a species mean LC50. Species mean LC50s for congeneric species should be geometrically averaged and those genus mean LC50s should be used in the calculations.

b Daphnids includes members of the genera Daphnia, Ceriodaphnia, and Simocephalus. 
APPENDIX C 
THIS PAGE INTENTIONALLY LEFT BLANK 


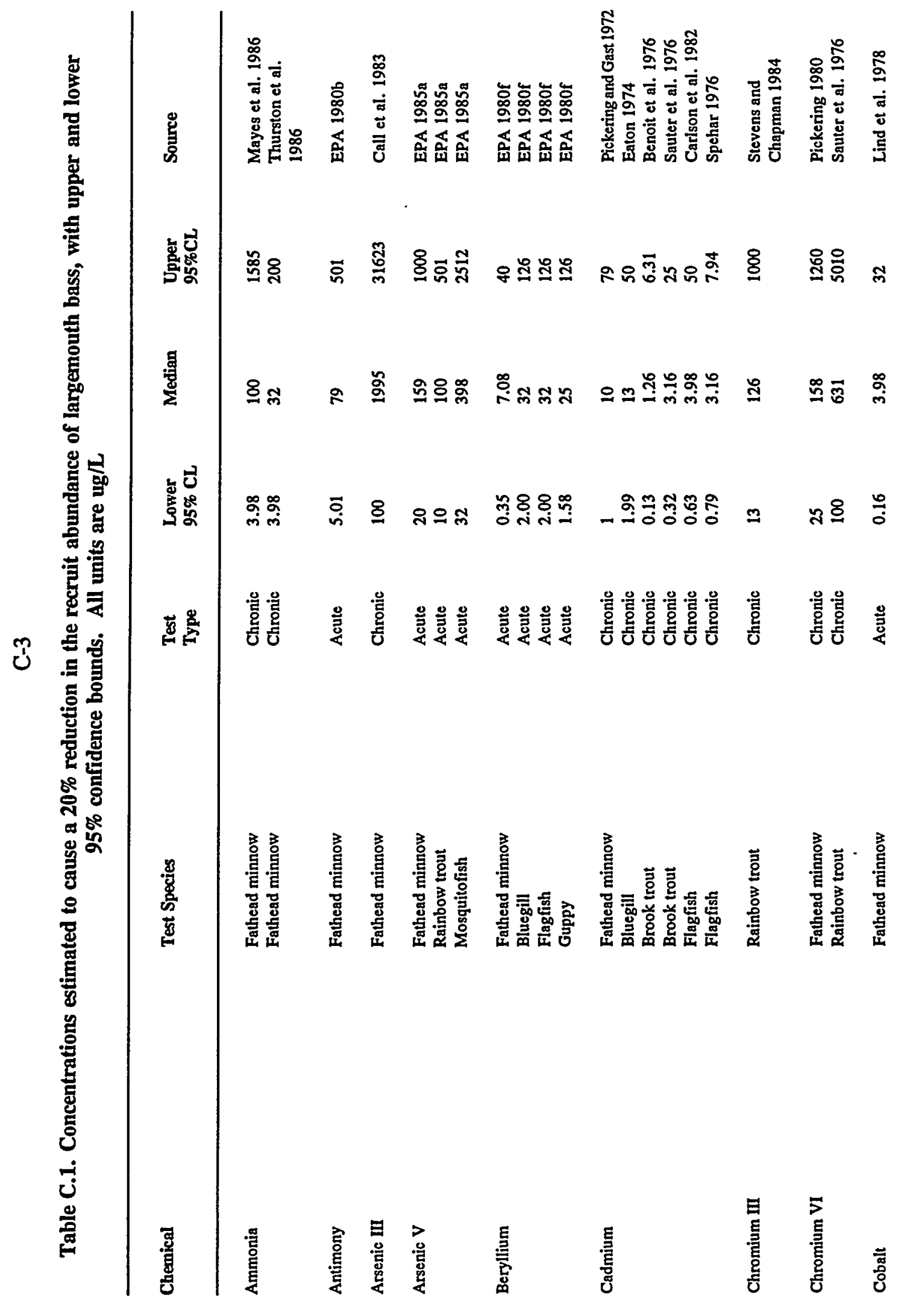




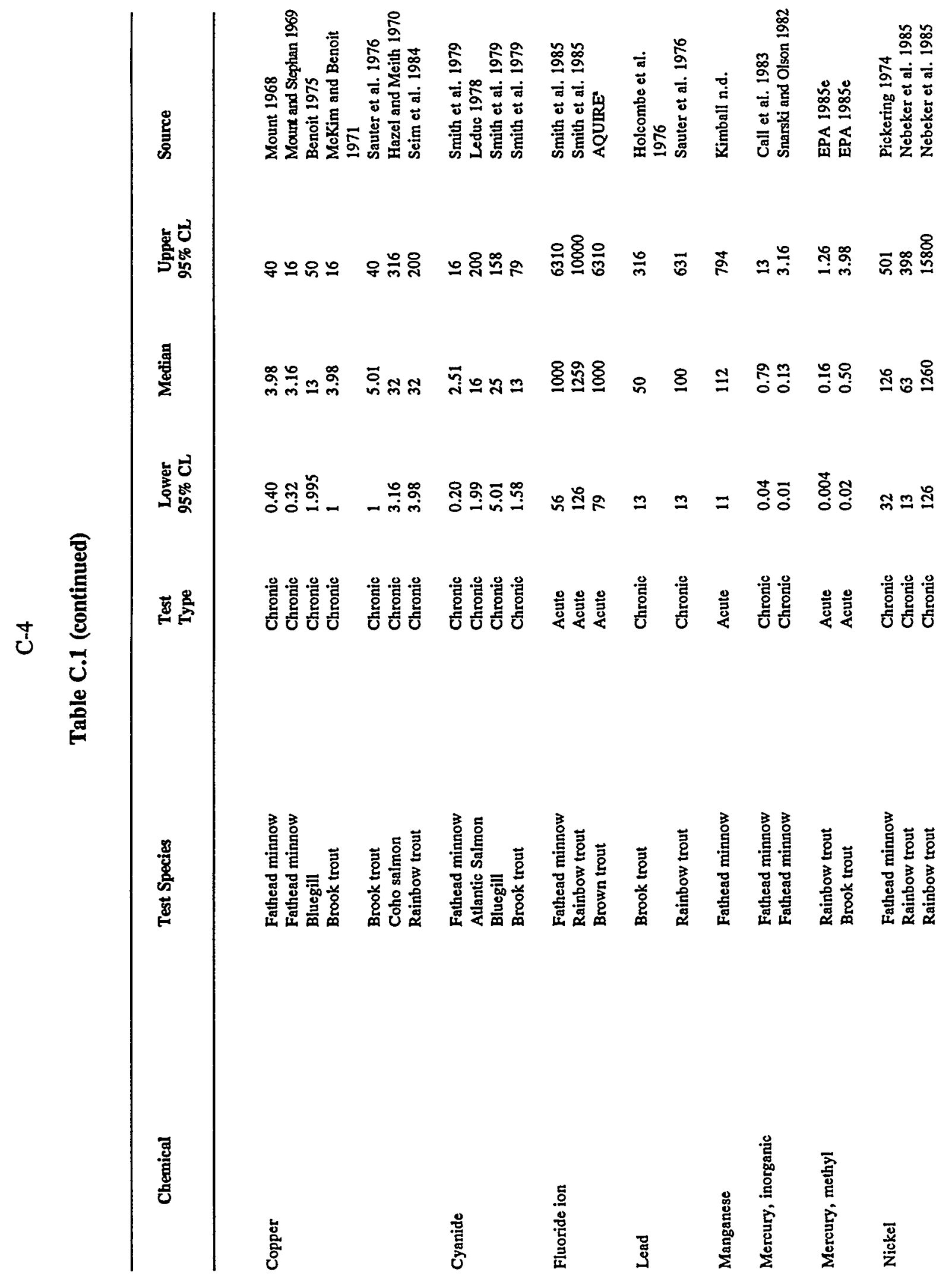




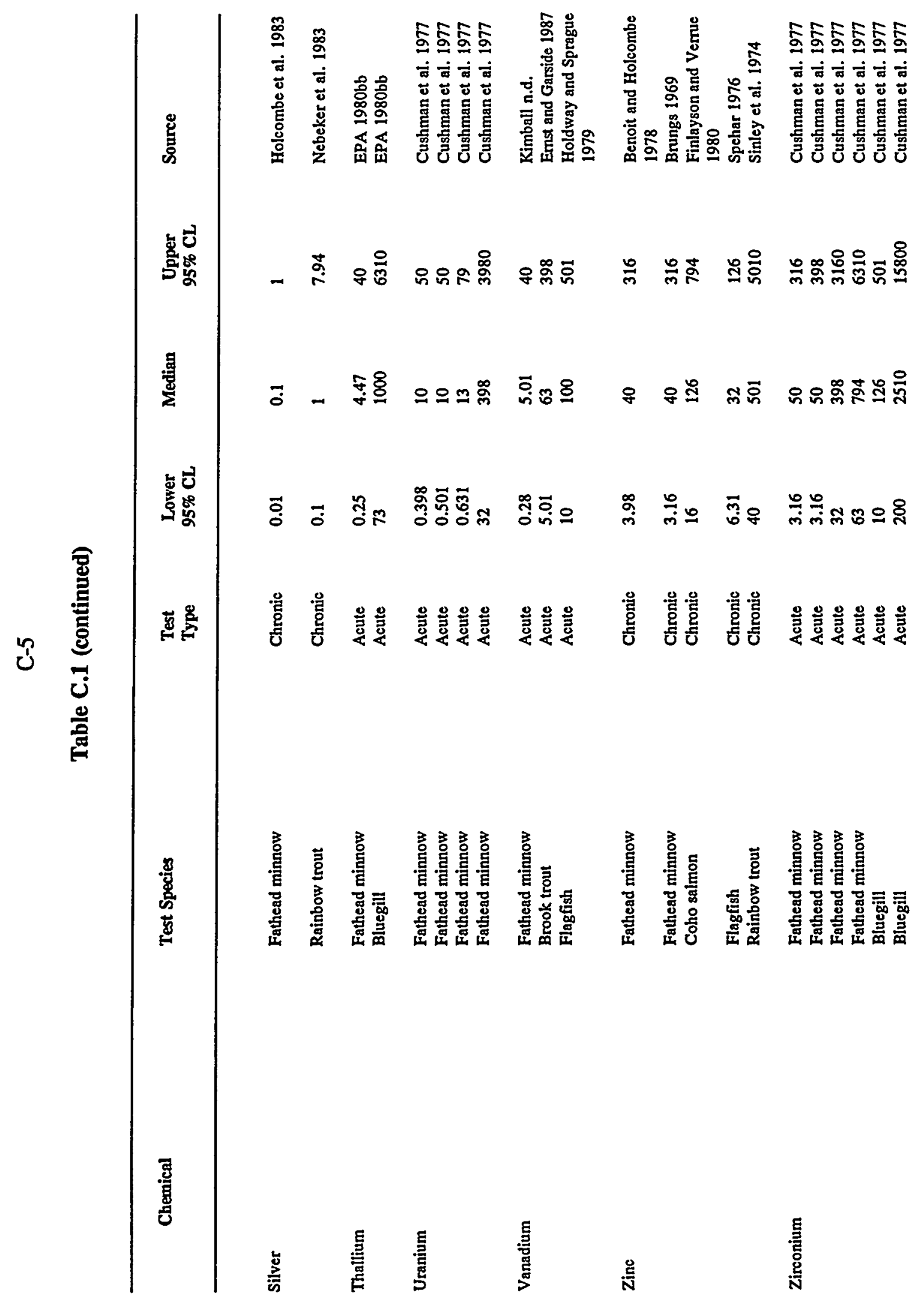




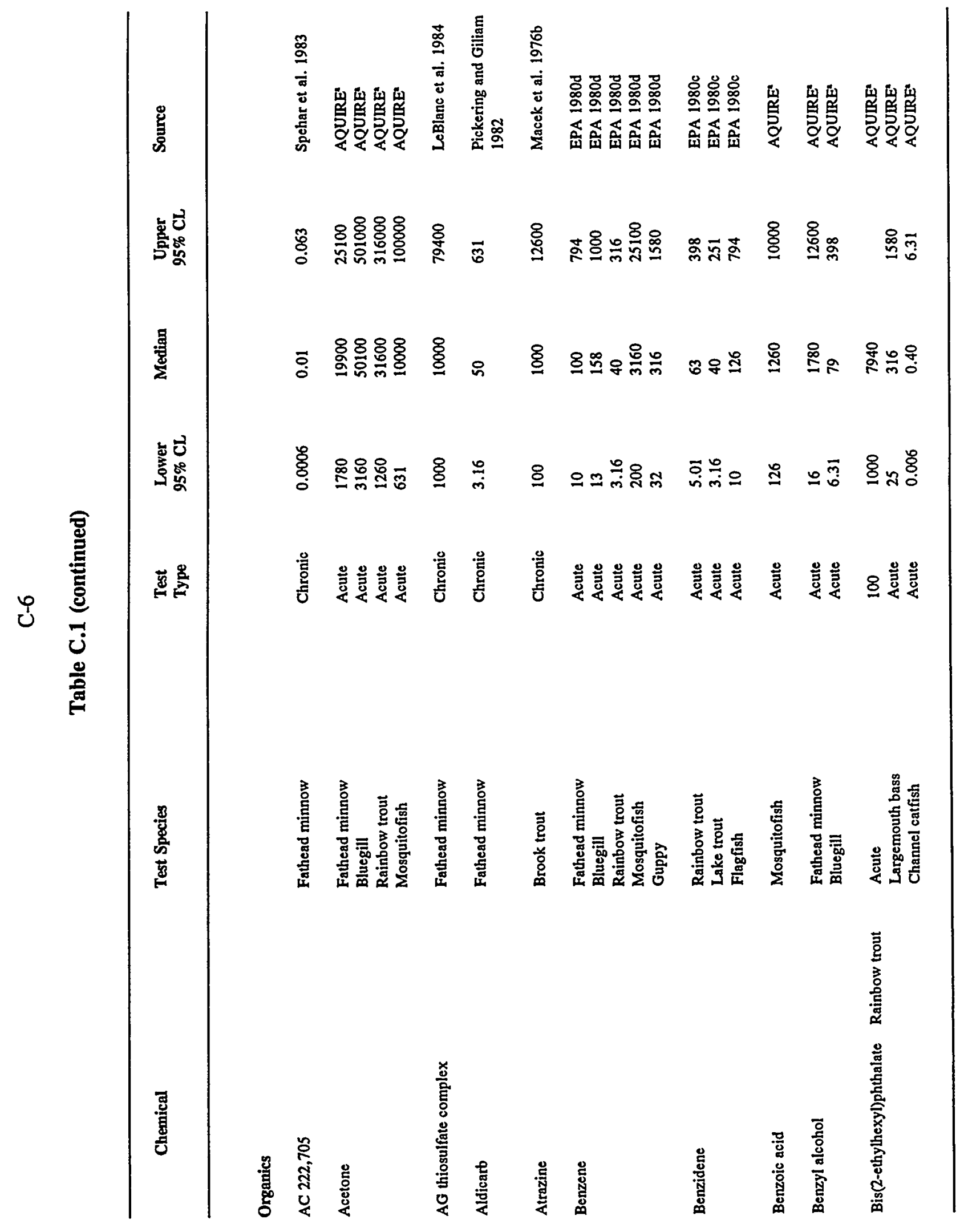




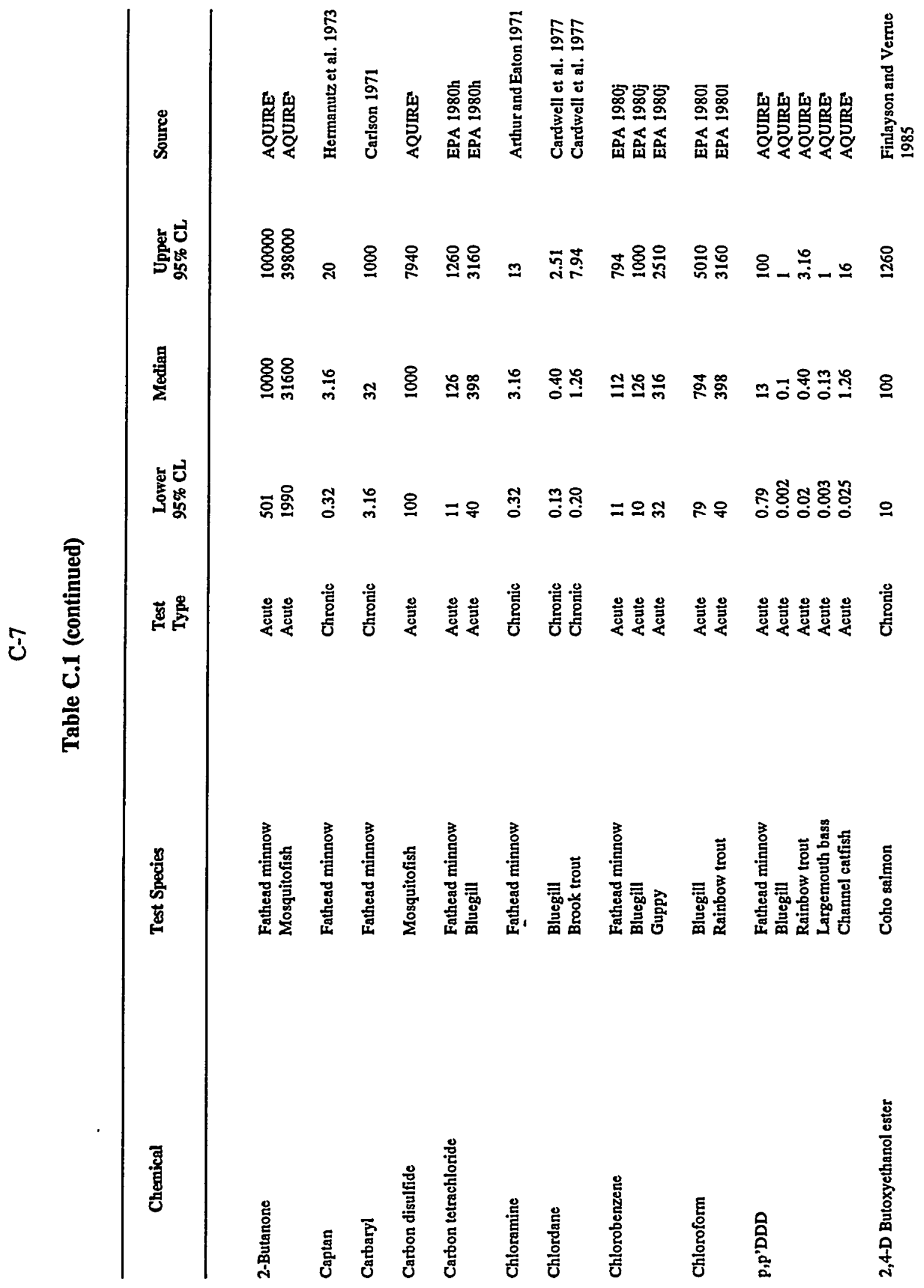




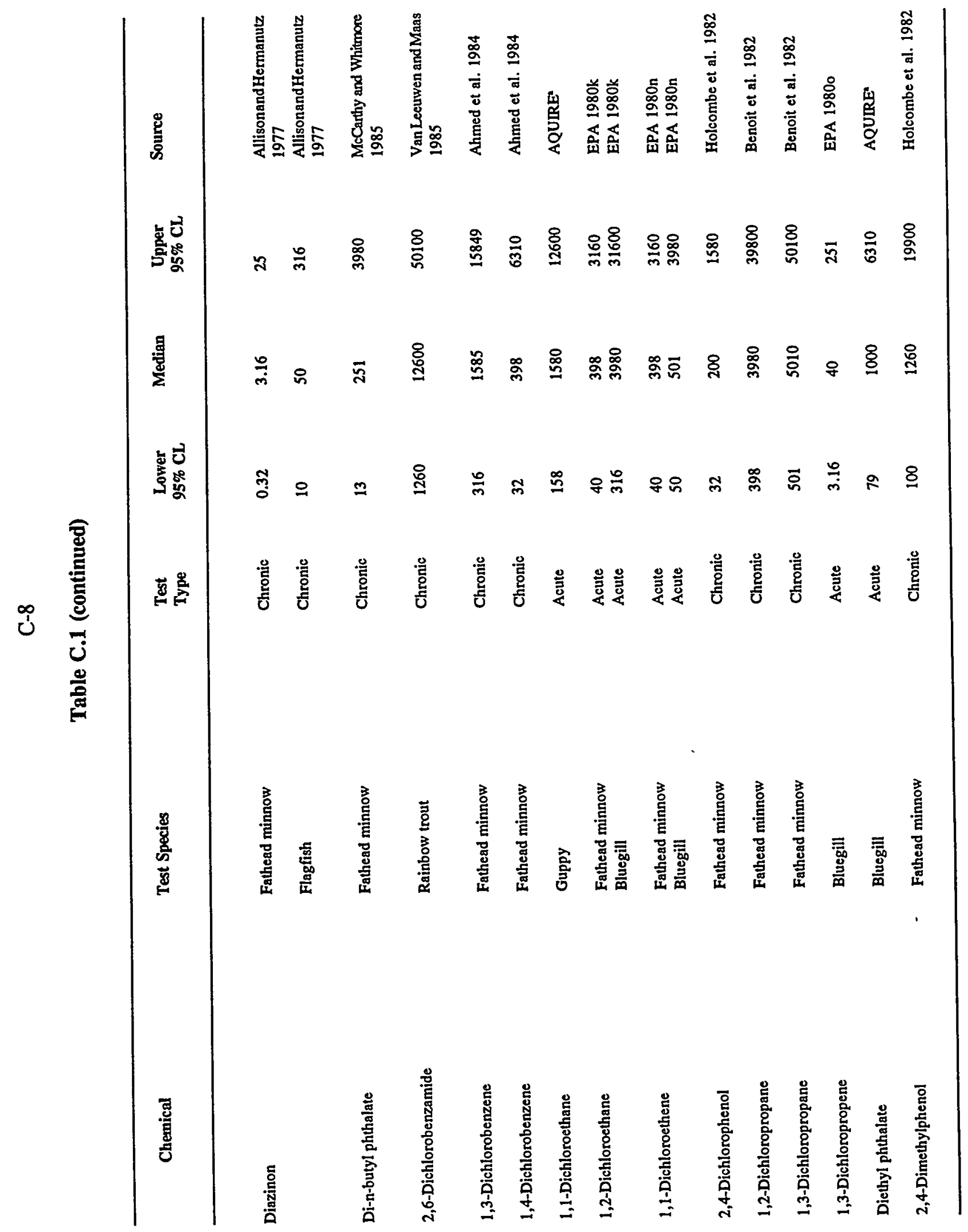




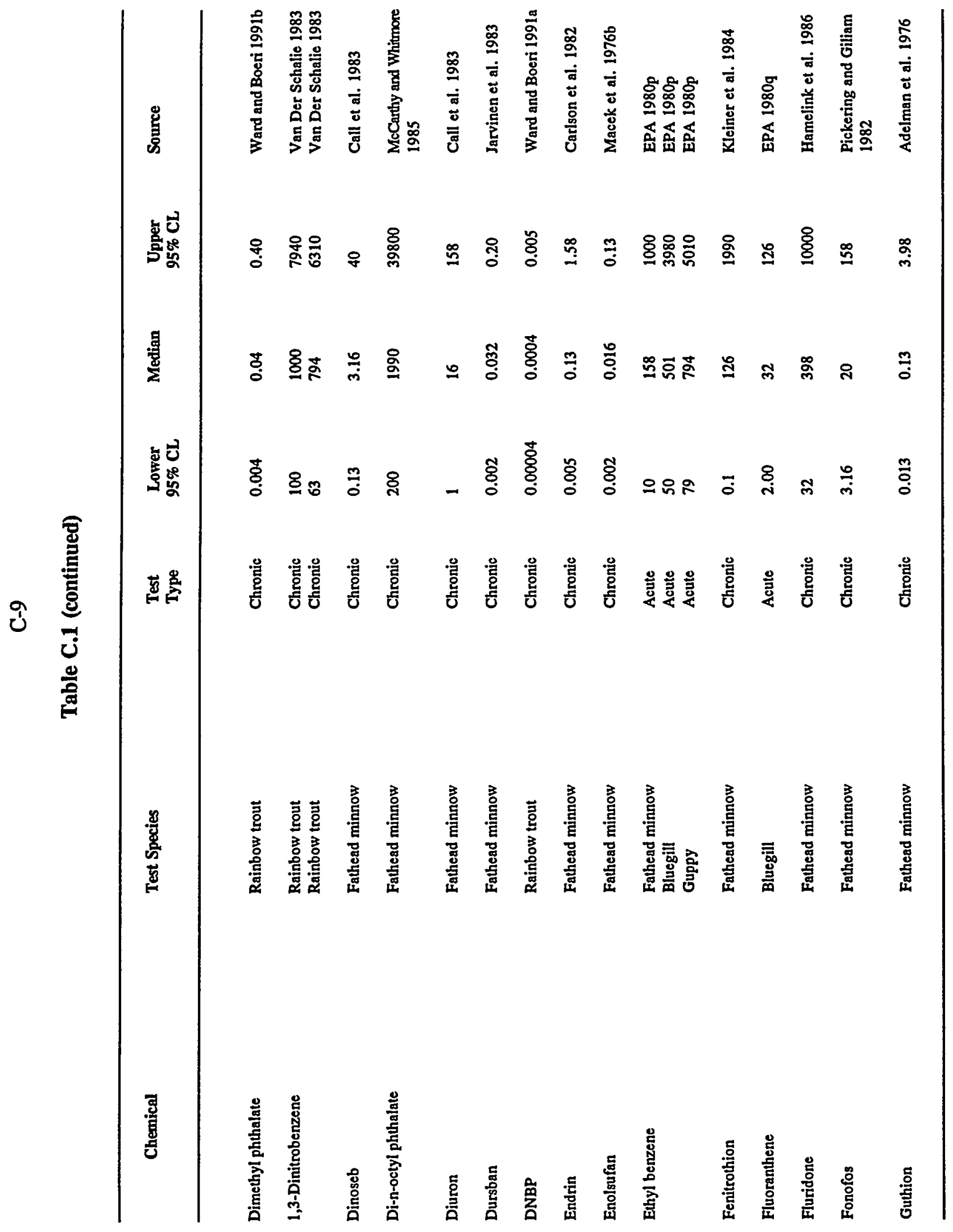




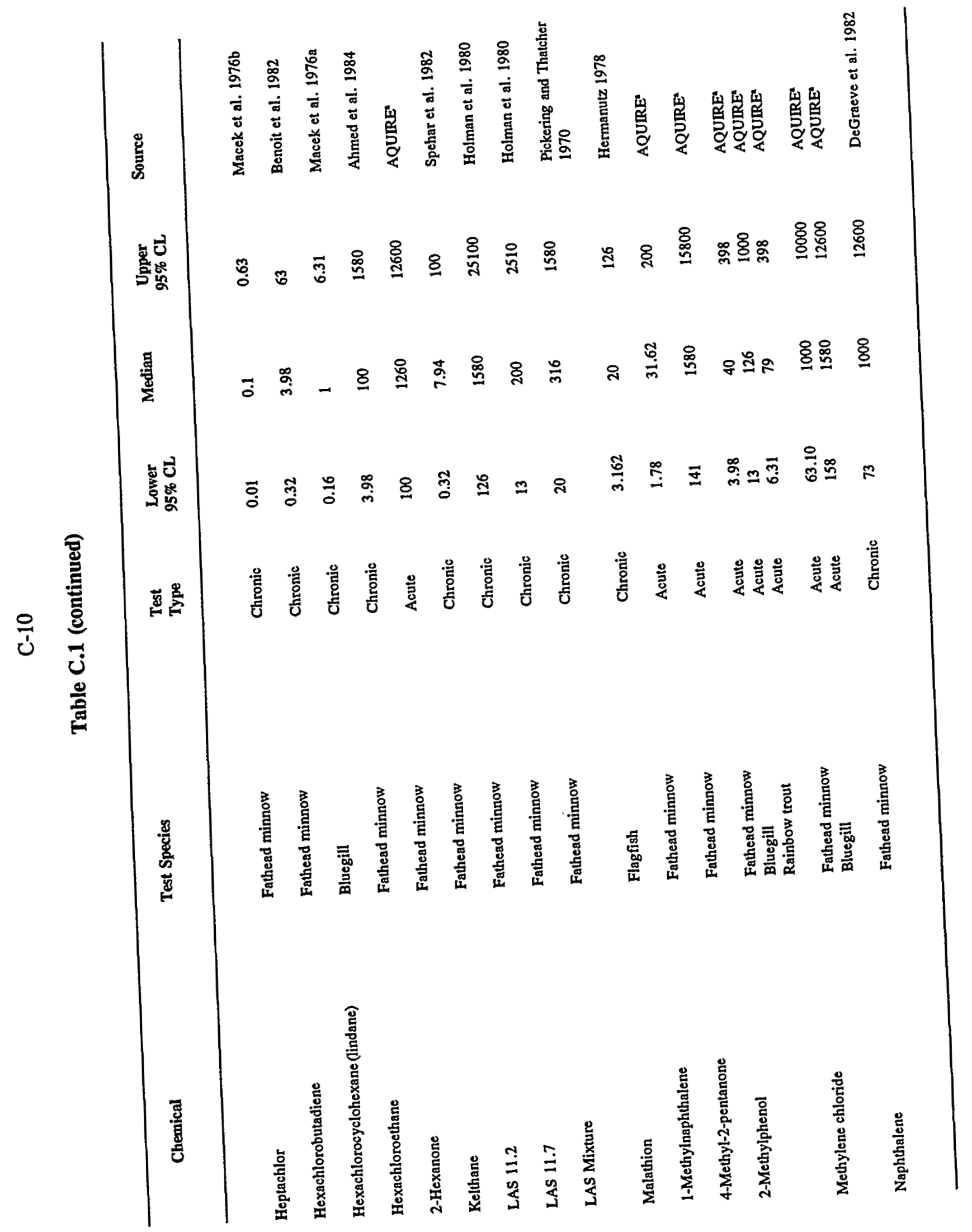




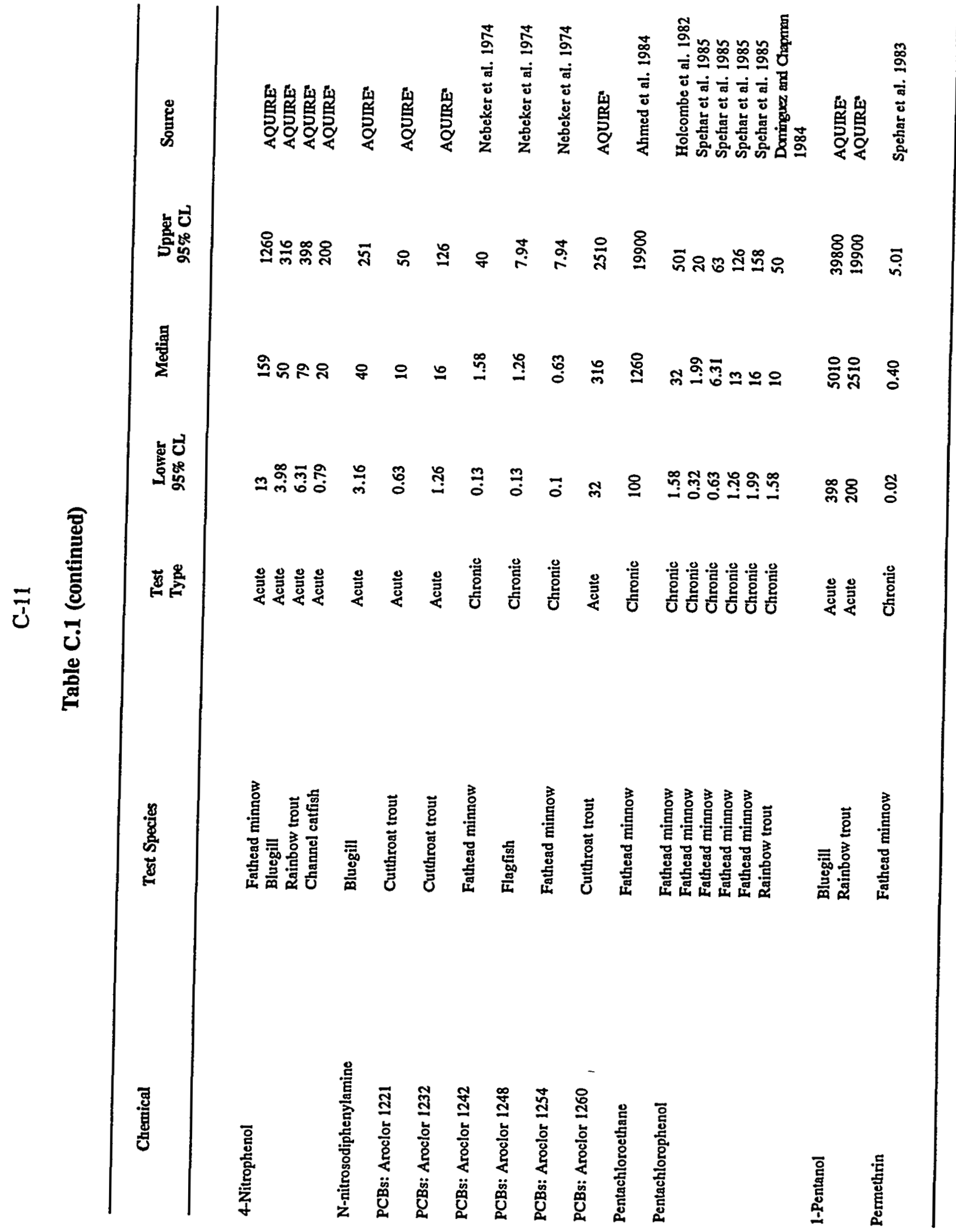




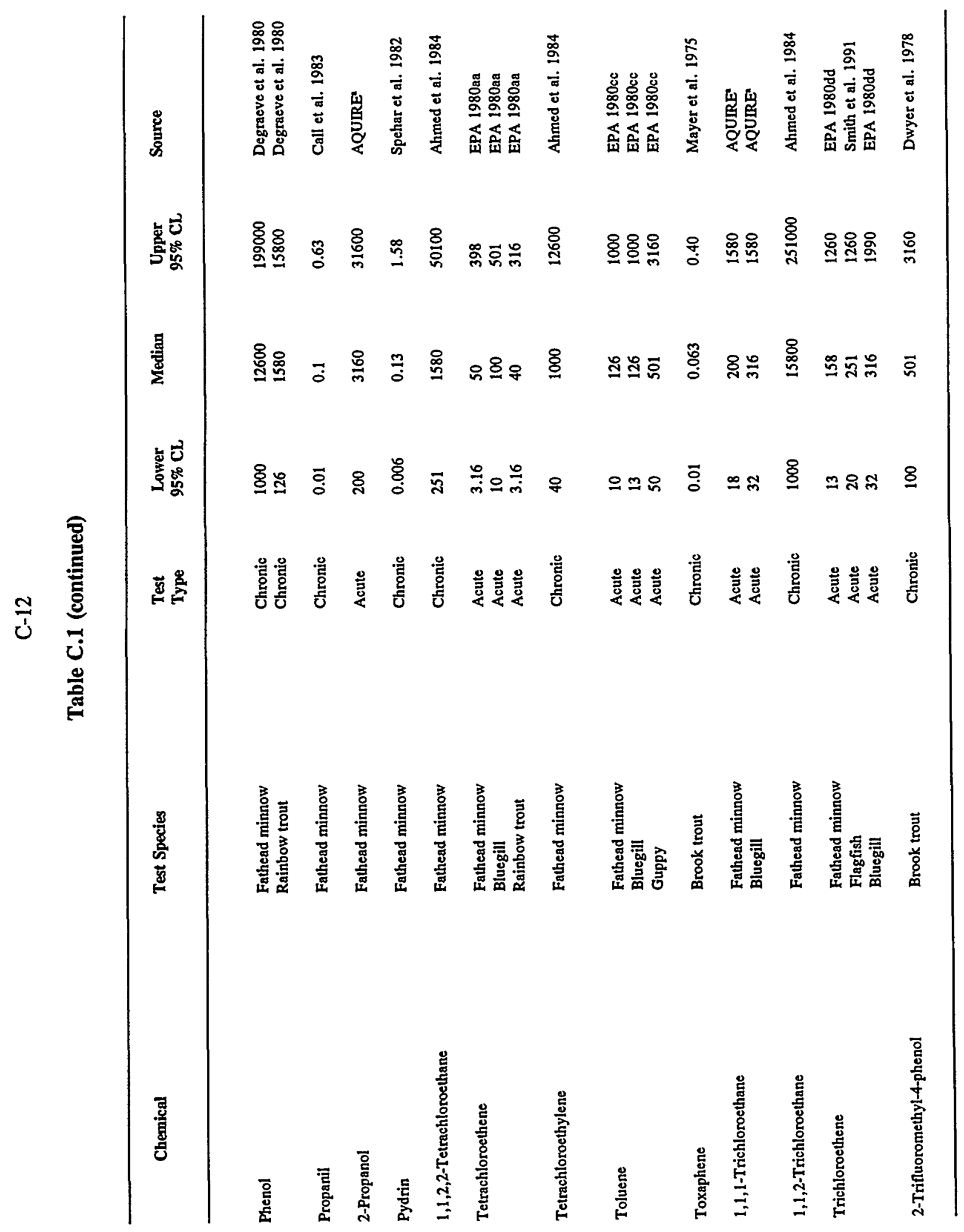




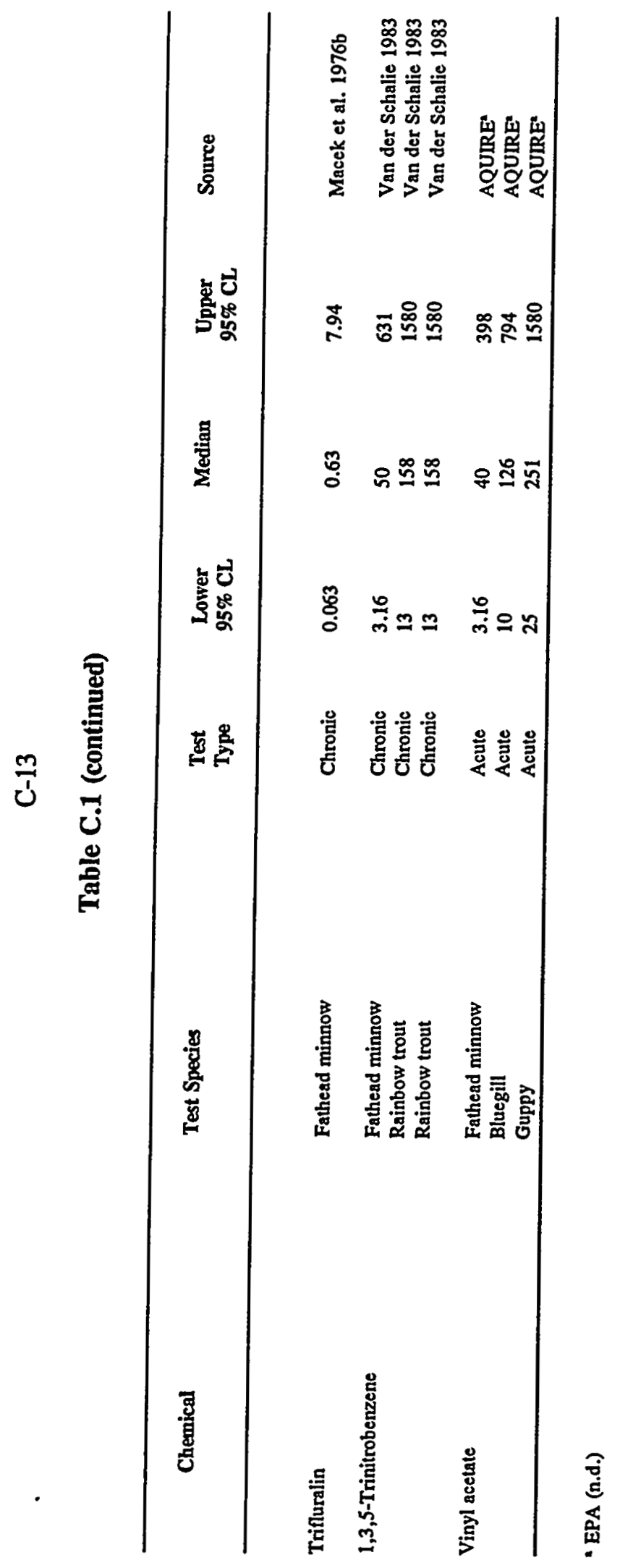




\section{DISTRIBUTION}

1. J. Archer

2. L. W. Barnthouse

3. Lisa Baron

4. B. G. Blaylock

5. R. R. Bonczek

6. M. Clauberg

7. J. Dee

8. J. R. Duncan

9. M. Ferré

10. D. Gonzales

11. R. N. Hull

12. D. S. Jones

13. R. C. Kramel

14. S. Lampkins

15. M. Leslie

16. R. Mathis

17-9. D. M. Matteo

20. C. W. McGinn

21. D. Mentzer

22. P. D. Miller

23. D. B. Miller
24. B. D. Nourse

25-6. P. T. Owen

27. S. Pack

28. S. T. Purucker

29. Sue Reith

30. B. Sample

31. M. E. Stack

32. D. M. Steinhauff

33. G. Stephens

34. G. W. Suter

35. Andrea Temeshy

36. C. C. Travis

37. C. J. E. Welch

38. R. K. White

39. Don Wilkes

40. Central Research Library

41-2. ER Document Management Center

43. Laboratory Records

44. ORNL Patent Section

45. J. B. Mabrey

46. Office of Assistant Manager for Energy Research and Development, DOE Oak Ridge Field Office, P.O. Box 2001, Oak Ridge, TN 37831-8600.

47. Office of Scientific and Technical Information (OST), P.O. Box 62, Oak Ridge, TN, 37831. 